Universidade de São Paulo

Instituto de Física de São Carlos

Instituto de Química de São Carlos

Escola de Engenharia de São Carlos

ESTUDO DA FORMAÇÃO E DAS

PROPRIEDADES ÓPTICAS DOS

OLIGÔMEROS DO ÁLCOOL

FURFURÍLICO EM SISTEMAS

CAPILARES

ase

Paulo dos Santos Batista

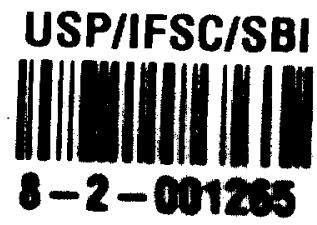

Dissertação apresentada a Área Interunidades, da Universidade de São Paulo do Campus de São Carlos , para obtenção do título de Mestre em Ciências e Engenharia de Materiais.

Orientador: Prof. Dr. Milton Ferreira de Souza

São Carlos

1999 
Batista, Paulo dos Santos

Estudo da formação e das propriedades ópticas dos oligômeros do álcool furfurílico em sistemas capilares/ Paulo dos Santos Batista - São Carlos, 1999.

92p.

Dissertação(Mestrado) - Instituto de Física de São Carlos, Instituto de Química de São Carlos, Escola de Engenharia de São Carlos, 1999.

Orientador: Prof. Dr. Milton Ferreira de Souza

1.Película 2. Propriedades Mecânicas

3. Propriedades Elétricas I. Título 


\section{Ciência e Engenharia de Materiais}

\section{UNIVERSIDADE DE SÃO PAULO}

Escola de Engenharia de São Carlos

Instituto de Física de São Carlos

Instituto de Química de São Carlos

CAIXA POSTAL - 369

CEP 13560-970 - São Carlos/SP - Brasil

Tel/Fax: (016) 273-9777

E-mail: erica@if.sc.usp.br

MEMBROS DA COMISSÃO JULGADORA DA DISSERTAÇÃO DE MESTRADO DE PAULO DOS SANTOS 回ATISTA, APRESENTADA A ÁREA INTERUNIDADES EM CIÊNCIA E ENGENHARIA DE MATERIAIS, DA EESC-IFSC-IQSC, UNIVERSIDADE DE SÃO PAULO, EM 23/2/1999.

\section{COMISSÃO JULGADORA:}
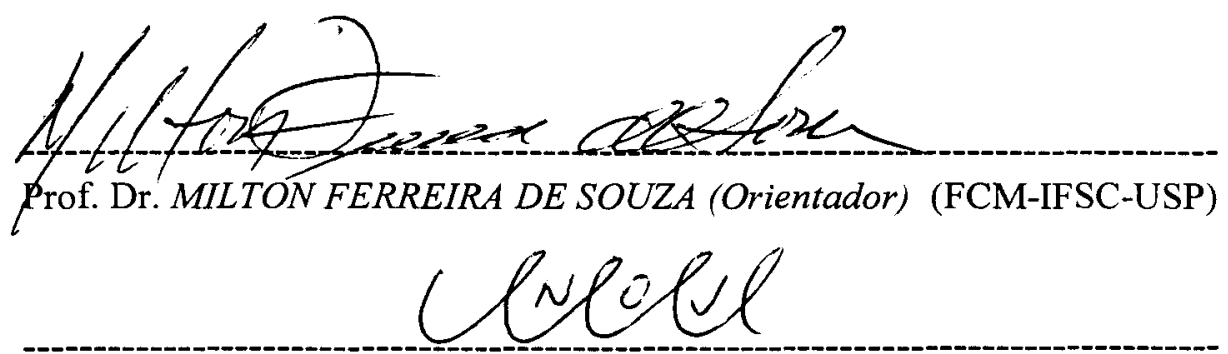

Prof. Dr. OSVALDO NOVAIS DE OLIVEIRA JUNIOR (FCM-IFSC-USP)

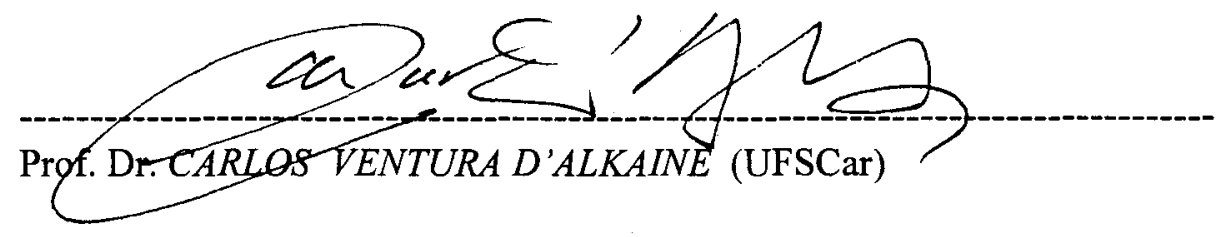


"...Navegar é preciso..."

\section{F. Pessoa}

Para Paula, Rosete e Rosinete, pelo que as palavras não podem dizer. 


\section{AGRADECIMENTOS}

Ao amigo e orientador Professor Milton Ferreira de Souza, pelos sábios ensinamentos.

A meus pais Rosete e Mário, companhias inseparáveis em todo o percurso.

Aos amigos e parceiros Cleber Renato Mendonça, Lino Misoguti e Marcio Galdino pela inestimável ajuda durante o decorrer do trabalho.

Aos companheiros de percurso Leonardo G. Patterno e Douglas de Britto, Fernando Rodrigo, Eduardo Araújo, Gustavo Accioli e Alexandre Costa, ainda vamos mudar o mundo!

Aos amigos de laboratório Deusdedit, Ignácio, Paulinho, Salete, Roberto, Jean, Washington, Joatan e Daniel pelos incentivos e comentários pertinentes.

A secretaria do Grupo de Óptica Isabel e ao Prof Dr.Yashiro Yamamoto, pela ajuda estratégica e constante durante todo o trabalho.

Ao Técnico da Oficina de Vidro Edivaldo, pela extrema paciência e presteza na confecção dos materiais.

A equipe da Oficina Mecânica do IFSC, pela atenção dispensada na confecção das aparelhagens.

Aos antigos e aos novos companheiros de República: Zé, Trovão Pedrinho, 64, Bráulio, Bigui, Rosana e Romário pela convivência agradabilíssima.

Ao CNPq e a FAPESP pelo suporte financeiro para realização do trabalho. 


\section{SUMÁRIO}

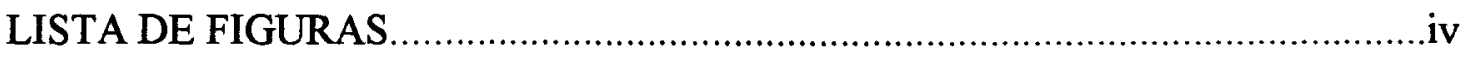

LISTA DE TABELAS ......................................................................................

RESUMO

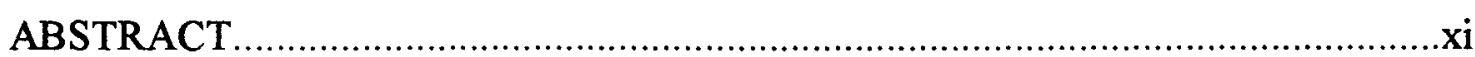

1-INTRODUÇÃO

2-REVISÃO BIBLIOGRÁFICA

2.1- HISTÓRICO

2.2- PRODUÇÃO INDUSTRIAL DO FURFURAL............................................

2.3-PRODUÇÃO INDUSTRIAL DO ÁLCOOL FURFURÍLICO ...............................

2.4-PROPRIEDADES DO ÁLCOOL FURFURÍLICO_............................................

2.5-POLIMERIZAÇÃO DO ÁLCOOL FURFURÍLICO.............................................

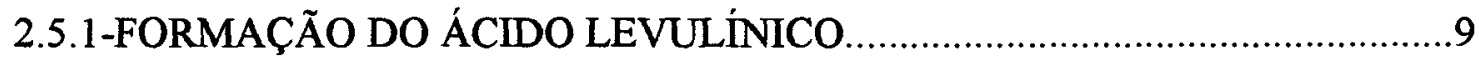

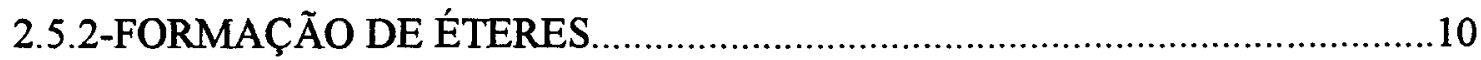

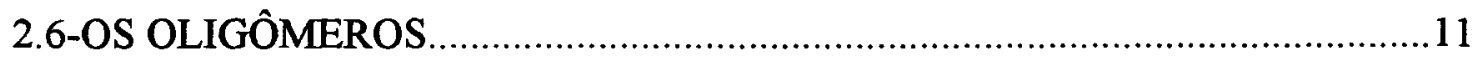

2.7- FORMAÇÃO DO ENTRECRUZAMENTO ..................................................13

2.8- COMPÓSITOS DE ÁLCOOL FURFURÍLICO E SÍLICA..................................15

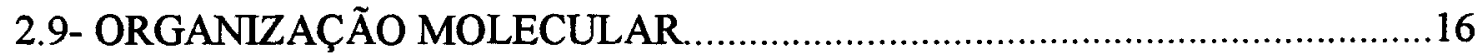

2.9.1- FILMES DE LANGMUIR-BLODEGETT .................................................19 
3- METODOLOGIA

3.1- PURIFICAÇÃO DO ÁLCOOL FURFURÍLICO..............................................21

3.2- ANÁLISE DA ÁLCOOL FURFURÍLICO …………………............................22

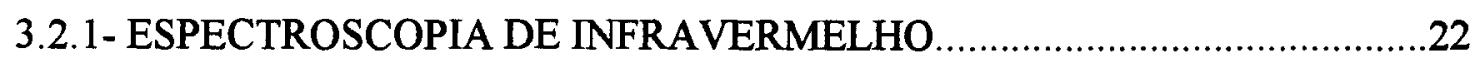

3.2.2- ESPSCTROSCOPIA DE RESSONÂNCIA MAGNÉTICA DE CARBONO E HIDROGÊNIO

3.2.3 - DETECÇÃO DA FLUORESCÊNCIA ……………………………………......23

3.2.4- TÉCNICAS CROMATOGRÁFICAS …….................................................23

3.2.4.1- CROMATOGRAFIA EM CAMADA DELGADA (TLC)............................23

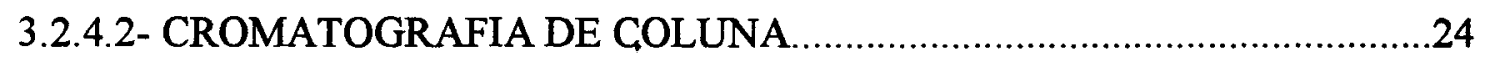

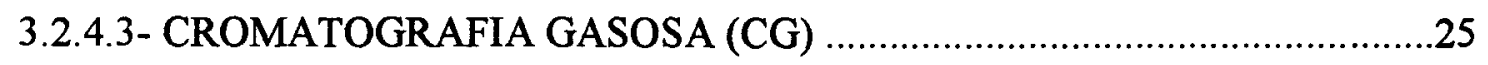

3.3-DETERMINAÇÃO DA VELOCIDADE LIMITE EM CAPILARES VERTICAIS .

3.4-DETERMINAÇÃO DA VELOCIDADE LIMITE EM CAPILARES HORIZONTAIS . .28

3.5- DETERMINAÇÃO DOS OLIGÔMEROS FORMADOS...................................29

3.6- PREPARAÇÃO DOS OLIGÔMEROS PARA MEDIDAS ÓPTICAS...............29

3.6.1- CATÁLISE ATRAVÉS DA SUPERFÍCIE DE CAPILARES AO VAPOR DE ÁCIDO

3.6.2- CATÁLISE ATRAVÉS DO BORBULHAMENTO.......................................

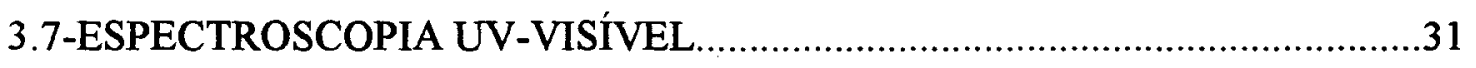

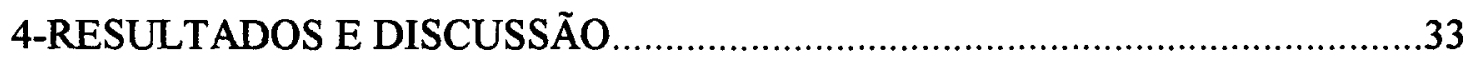

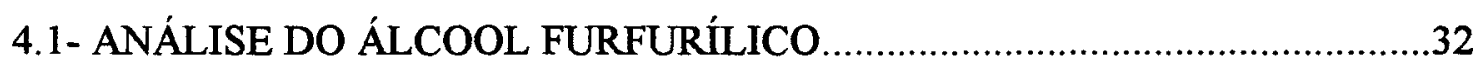

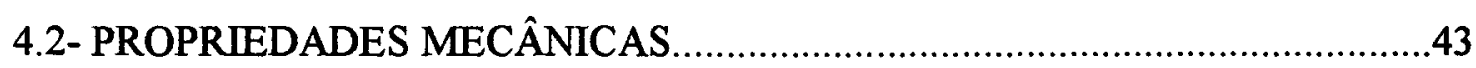

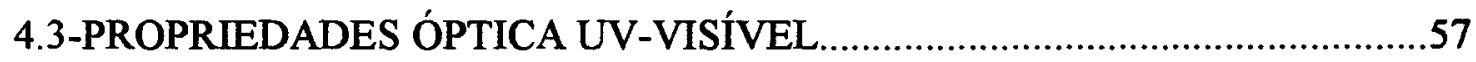




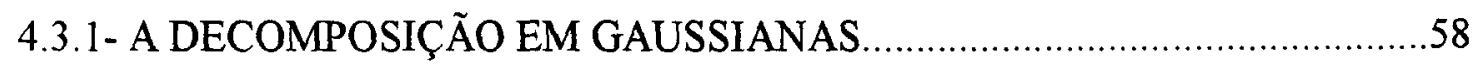

4.3.2- POLIMERIZAÇÃO EM CAPILARES DE VIDRO ....................................59

4.3.2.1-SOLUÇÃO DE OLIGÔMEROS USANDO CAPILAR DE RAIO $0.85 \mathrm{~mm}$ 59

4.3.2.2-SOLUÇÃO DE OLIGÔMEROS USANDO CAPILAR DE RAIO $1.1 \mathrm{~mm}$ 62

4.3.2.3-POLIMERIZAÇÃO ATRAVÉS DO BORBULHAMENTO DO VAPOR

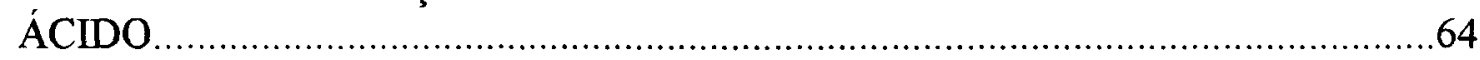

4.3.3-NEUTRALIZAÇÃO COM TRIETILAMINA............................................67

4.3.4-SOLUÇÃO DE ÁLCOOL FURFURÍLICO DE COR AMARELA.................69

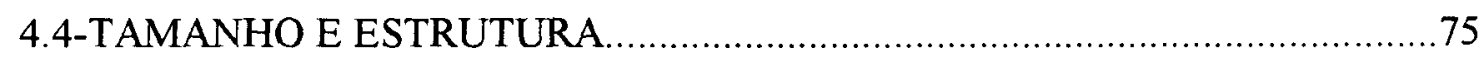

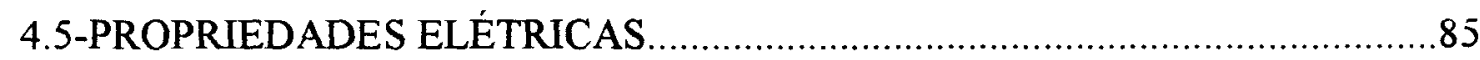

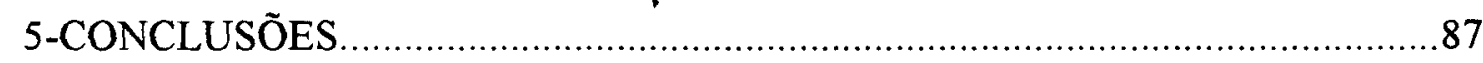

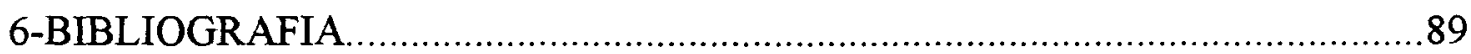




\section{LISTA DE FIGURAS}

Figura 2.1 - D-Arabinose e D-Xilose, precursores naturais do furfural.......................4

Figura 2.2- Molécula de Álcool Furfurílico e do Furfural.............................................6

Figura 2.3-Estruturas de ressonância do anel furânico................................................

Figura 2.4- Reação de obtenção de polímeros do Álcool Furfurílico.............................8

Figura 2.5-Mecanismo de formação do ácido levulínico.............................................10

Figura 2.6-Mecanismo de formação do cromóforo....................................................12

Figura 2.7-Ramificações na estrutura dos oligômeros..............................................14

Figura 2.8-Formação de um Diels-Alder...............................................................14

Figura 2.9-Interação de um oligômero com a sílica...................................................16

Figura 2.10-Representação esquemática de uma micela.............................................17

Figura 2.11-Representação esquemática de uma vesícula............................................18

Figura 2.12- Representação esquemática de uma micro-emulsão...............................18

Figura 2.13-Representação esquemática da formação de filmes de Languimuir-

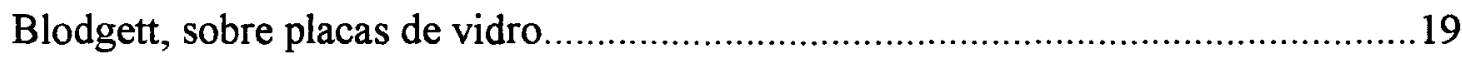

Figura 3.1- Esquema da aparelhagem de destilação do álcool furfurílico ..................21

Figura 3.2-Esquema de determinação da velocidade limite da frente azul dentro dos capilares de tubos de vidro de borosilicato.............................................................2

Figura 3.3- Aparelhagem usada para estudar a propagação da frente de cor azul nos tubos capilares com uma parte na horizontal. 
Figura 3.4- Aparelhagem para obtenção da solução de oligômeros do álcool furfurílico, através da catálise da superficie de capilares de borosilicato usando vapor de ácido cloridrico.

Figura 4.1-Espectro de Absorção ótica UV-VIS do Álcool Furfurílico. .34

Figura 4.2-Espectro de Transmissão no infravermelho do Álcool Furfurílico 35

Figura 4.3-Espectro Pendant de Ressonância Magnética de Carbono do Álcool Furfurílico 35

Figura 4.4-Espectro de Ressonância magnética de prótons do Álcool Furfurílico. 36

Figura 4.5-Variação da potência da da luz laser de $\lambda=514 \mathrm{~nm}$ e observação da fluorescência para o álcool furfurílico destilado. 37

Figura 4.6-Espectro de Massa do composto obtido por separação através de cromatografia gasosa. 40

Figura 4.7-Representação da estrutura do composto obtido através da fragmentação do espectro de massa relativa ao tempo de retenção de $11.59 \mathrm{mim}$.

Figura 4.8-Determinação do Coeficiente de Extinção do AF. .42

Figura 4.9-Representação esquemática da frente que se desloca no capilar de vidro borosilicato 43

Figura 4.10-Determinação da velocidade limite para capilares verticais de borosilicato, com raio até $0.25 \mathrm{~cm}$. 44

Figura 4.11-Determinação da velocidade limite para capilares verticais de borosilicato, com raio até $0.6 \mathrm{~mm}$. 45

Figura 4.12-Determinação da relação de $\mathrm{V} / \mathrm{R}^{2}$ para capilares de borosilicato. .46

Figura 4.13-Determinação da velocidade limite de queda da frente azul em função da densidade da solução $\mathrm{AF} / \mathrm{DCM}$. 47

Figura 4.14-Dependência da velocidade limite na queda da frente azul em função da densidade da solução AF/DCM. 48

Figura 4.15-Representação esquemática das forças que agem sobre a película que se forma sobre a superficie do capilar. 
Figura 4.16-Representação do mecanismo de formação da película e seu rompimento a partir da superfície do tubos capilares raio superior a $2.7 \mathrm{~mm}$ 50

Figura 4.17-Correlação entre o tempo e a distância de percurso da frente nos capilares com o braço horizontal. 56

Figura 4.18-Representação gráfica dos termos da equação Gaussiana sob a curva.

Figura 4.19-Espectro de absorção ótica UV-Visível da solução de cor azul, obtida através da catálise do álcool furfurílico exposto na superficie de capilares de borosilicato com raio de $0.85 \mathrm{~mm}$. .60

Figura 4.20-Decomposição em Gaussianas do espectro ótico da solução azul obtida através da catálise da superficie do capilar de vidro com raio $0.85 \mathrm{~mm}$. 60

Figura 4.21- Comparação entre a soma das Gaussianas e o espectro de absorção ótica medido, entre $200 \mathrm{~nm}$ e $1000 \mathrm{~nm}$.

Figura 4.22-Espectro de absorção ótica UV-Visível da solução de cor azul, obtida através da catálise do álcool furfurílico exposto na superficie de capilares de borosilicato com raio de $1.1 \mathrm{~mm}$. .62

Figura 4.23-Decomposição em curvas Gaussianas do espectro de absorção ótica UVVisível da solução de álcool furfurílico de cor azul. Solução obtida através da catálise ácida do álcool exposto na superfície do capilar de borosilicato de raio $1.1 \mathrm{~mm}$ .63

Figura 4.24-Comparação entre o espectro absorção ótica UV-Visível da solução de álcool furfurílico de cor azul, em preto. Solução obtida através da catálise ácida do álcool exposto na superfície do capilar de borosilicato de raio $1.1 \mathrm{~mm}$ e a soma das curvas Gaussianas obtidas através da decomposição do espectro original, em vermelho

Figura 4.25-Espectro de absorção ótica UV-Visível da solução de cor azul, obtida através do borbulhamento de vapor de ácido clorídrico e gás nitrogênio. Para referência foi usada uma solução de álcool furfurílico e DCM .65

Figura 4.26-Decomposição em curvas Gaussianas do espectro de absorção ótica UVVisível da solução de álcool furfurílico de cor azul. Solução obtida através do borbulhamento do ácido clorídrico com gás nitrogênio.

Figura 4.27-Comparação entre o espectro absorção ótica UV-Visivel, em preto. E em vermelho temos a soma das curvas Gaussianas obtidas através da decomposição do espectro original. 
Figura 4.28-Espectro de absorção ótica UV-Visível da solução de cor laranja.

Figura 4.29-Decomposição em curvas Gaussianas do espectro de absorção ótica UVVisível da solução laranja obtida após a neutralização com trietilamina. 68

Figura 4.30-Comparação do espectro de absorção ótica UV-Visível da solução laranja obtida após a neutralização com trietilamina. 68

Figura 4.31- Espectro de absorção ótica do AF em solução quando a mesma apresenta-se amarelada. 70

Figura 4.32-Espectro de massa obtido através da técnica CG-MS, onde foi selecionado para análise o pico com TR de $13.05 \mathrm{~min}$. 71

Figura 4.33-Possível composto com TR $13.05 \mathrm{~min}$ obtido por separação cromatográfica na solução amarela. .71

Figura 4.34-Decomposição do espectro de absorção ótica em Gaussianas, onde em verde podemos ver a duas curvas e em preto a curva experimental normalizada......73

Figura 4.35-Comparação entre o espectro de absorção ótica medido em preto, e a soma de duas Gaussianas, em vermelho, obtidas através da decomposição do espectro original. 73

Figura 4.36-Relação entre as alturas relativas aos máximos das curvas Gaussianas obtidas, através da decomposição dos espectros de absorção ótica das soluções de oligômeros do álcool furfurílico.

Figura 4.37-Tautomerismo da molécula enólica formada pela presença de conjugação em molécula de número pares de mero. 83

Figura 4.38-Representação do perfil da medida da resistência quando acontece a polimerização do álcool furfurílico .86 


\section{LISTA DE TABELAS}

Tabela 1-Porcentagem de furfural obtido em fontes vegetais.

Tabela 2-Condições experimentais usadas para a análise cromatográfica.

Tabela 3-Determinação da pureza do Álcool Furfurilico incolor com absorção máxima em $270 \mathrm{~nm}$, através de cromatografia Gasosa.

Tabela 4-Compostos gerados a partir da resinificação térmica do AF através do processo de destilação à pressão reduzida e sua concentração relativa.

Tabela 5- Tempo de Retenção com concentração relativa na fração apolar, obtida por separação através de cromatografia de coluna.

Tabela 6-Tempo de Retenção com concentração relativa na fração polar, obtida por separação através de cromatografia de coluna.

Tabela 7-Distribuição de compostos na fração separada através de cromatografia de coluna e enriquecida em compostos.

Tabela 8-Velocidade limite para queda da frente azul nos capilares de borosilicato. 45

Tabela 9-Comparação entre o valor da velocidade limite e a densidade da Solução.

Tabela 10-Dependência do tempo de deslocamento da frente em um ramo horizontal de um capilar de $0.11 \mathrm{~cm}$ de raio.

Tabela 11-Anamorfismo dos dados experimentais. .55

Tabela 12-Aonde: abs $_{0}=$ linha de base $; \lambda_{\max }=$ comprimento de onda correspondente a máxima absorção. A e W constantes da equação (18); $\lambda_{\max }=$ máxima absorção ótica; $\Delta \lambda=$ largura da banda para $a b s_{\max } / 2$ que é igual a w/0.85. 61

Tabela 13-Valores relacionados com a construção das Curvas Gaussianas. 64 
Tabela 14-Parâmetros das Gaussianas obtidas da decomposição do espectro de absorção ótica da solução original, bem como suas características.

Tabela 15-Parâmetros de construção das curvas Gaussianas obtidas a partir da

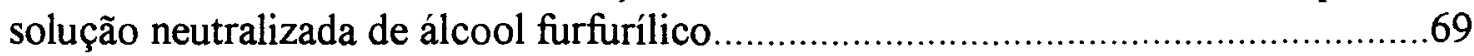

Tabela 16-Composição da solução de cor amarela do Álcool Furfurílico..................70

Tabela 17-Relação entre os fragmentos obtidos no espectro de massa e sua possível estrutura.

Tabela 18-Parâmetros de construção das curvas Gaussianas obtidos através da

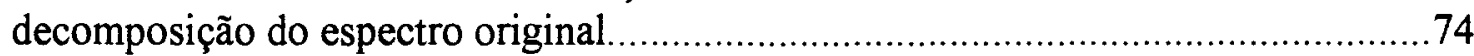

Tabela 19-Relação da áreas sob as curvas Gaussianas representadas pelo seu comprimento de onda na máxima absorção, nas diferentes soluções de álcool furfurílico 76

Tabela 20-Relação da alturas sob as curvas Gaussianas representadas pelo seu comprimento de onda na máxima absorção, nas diferentes soluções de álcool furfurilico.

Tabela 21-Avaliação do tamanho da conjugação $(\mathrm{N})$, com relação ao comprimento da cadeia $L$ estimado e o observado, com os respectivos erros.

Tabela 22-Avaliação do tamanho da conjugação $(\mathrm{N})$, com relação ao comprimeto da cadeia estimado e o observado, com os respectivos erros. 82 


\section{RESUMO}

Estudou-se a polimerização do álcool furfurílico líquido na interface nonômero-catalisador delimitada pelo interior de um tubo de vidro capilar. A superficie do álcool furfurílico líquido contido em um tubo de vidro de diâmetro interno inferior a $5.4 \mathrm{~mm}$ foi exposta aos vapores de ácido clorídrico concentrado, o catalisador. Observou-se a formação de uma película auto-organizada e colorida na interface que, sob a ação da gravidade, cai para o interior do tubo com velocidade constante. $\mathrm{O}$ espectro de absorção óptica identificou a formação de oligômeros com picos de absorção em $570 \mathrm{~nm}, 650 \mathrm{~nm}, 770 \mathrm{~nm}$ e $930 \mathrm{~nm}$, sendo a de $650 \mathrm{~nm}$ a mais intensa e possivelmente associada a, um oligômero com cinco meros. A distribuição de peso molecular dos oligômeros difere fortemente daqueles formados por catálise homogênea. A condutância dessas películas foi observada medindo-se a resistência elétrica de películas formadas sobre uma placa invertida de vidro plano. 


\begin{abstract}
The polymerization of furfuryl alcohol in the interface alcohol-concentrated hydrochloric acid vapor was studied inside glass tubes whose internal diameter were smaller than $5.4 \mathrm{~mm}$. Shortly after exposition of furfuryl alcohol to the acid vapor an auto organized bluish pellicle is generated that under gravity falls inside the tube with constant velocity. The observed optical absorption spectrum peaks at $570 \mathrm{~nm}$, $650 \mathrm{~nm}, 770 \mathrm{~nm}$ and $930 \mathrm{~nm}$ were attributed to oligomers with 3, 5, 7 and 9 mers, respectively. The optical absorption band at $650 \mathrm{~nm}$ being the stronger. The oligomers molecular weight distribution so formed was found to strongly differ of the ones formed by homogeneous catalysis. The electrical conductivity of these pellicles, made of conjugated oligomers, were observed measuring the electrical resistance of pellicles specially made on the flat inverted glass plate.
\end{abstract}




\section{1-INTRODUÇÃO}

O álcool furfurílico, AF, é um produto da redução catalítica do furfural, que por sua vez é obtido do processamento dos rejeitos agrícolas gerados na produção do milho, da aveia, do álcool e da madeira $[1,2]$. O estudo desse álcool teve um grande impulso durante a segunda grande guerra [1], pois apresentava-se como uma importante fonte alternativa de monômero. Este monômero, obtido de fontes renováveis, pode ser convertido em polímero [1-4].

A polimerização do álcool se dá por condensação e acontece quando há presença de um catalisador ácido. Essa reação de polimerização é sensível a concentração, ao caráter ácido do catalisador empregado e a temperatura [4-7]. 0 estudo dos primeiros estágios da polimerização em sistemas capilares iniciados com este trabalho demonstra que além dos fatores químicos conhecidos que influenciam a reação, um outro de natureza física se manifesta alterando a formação desses oligômeros. Este trabalho apresenta sua característica inédita quando explora o efeito da catálise do monômero na interface monômero-ácido em capilares de vidro borosilicato, isto como alternativa para controle do tamanho dos oligômeros que são formados. O tamanho dessas moléculas de oligômeros pode ser estimado, através de métodos teóricos correntemente usados para outras moléculas $[8,9]$.

O trabalho estuda o comportamento da reação de polimerização do álcool em sistemas capilares [10], como possível alternativa ao controle da formação das 
cadeias de polímeros com propriedades condutoras [6]. Os resultados deste estudo também podem ser úteis no entendimento da impregnação de meios porosos por resinas termofixas, formadas in situ [10-13]. 


\section{2-REVISÃO BIBLIOGRÁFICA}

\section{1-HISTÓRICO}

O primeiro estudo dos compostos furânicos data de (1780), quando Scheele [4] obteve ácido furóico como um produto da destilação seca do ácido múcico. Em (1832) Dobereimer [4] estudando a produção de ácido fórmico usando açúcar, dióxido de manganês e ácido sulfúrico descobre que após a destilação formavam-se pequenas gotas amarelas. Esse produto recebeu inicialmente o nome de óleo artificial de formigas, e logo depois passou a se chamar furfural. A correlação das duas experiências foi feita por Schwarnet (1860) [4] que através da oxidação do furfural usando ouro, obteve ácido furóico provando a correlação dos experimentos anteriores.

Nesta mesma época, Stenhouse (1850) [4] especulava sobre a natureza de compostos vegetais como fonte de furfural baseando sua hipótese na presença em todas as plantas do furfural ou composto similar. Para isso investigou certos tipos de algas, e encontrou uma mistura de furfural e 5-metilfurfural. Em (1920) Ricard [4], registra uma patente relacionando a formação de furfural a partir de produtos ligno-celulósicos.

Dentre as fontes naturais relacionadas para produção de furfural estão as celuloses, polioses, ácidos poliurônicos e lignina [4]. As celuloses e as polioses são 
compostas por várias unidades de açúcares, como pentosanos e hexosanos. A hidrólise ácida dos pentosanos gera pentoses simples como xilose e arabinose, figura 2.1 , sendo a xilose apontada como a maior fonte de produção do furfural $[1,4]$. Estudos na década de 50 relacionam a produção de furfural com fontes vegetais, como mostra a tabela (1).

Tabela 1-Porcentagem de furfural obtido em fontes vegetais

\begin{tabular}{|c|c|}
\hline Material Bruto & Furfural obtido do material seco (\%) \\
\hline Sabugo de milho & 23.4 \\
\hline Casca de aveia & 22.3 \\
\hline Casca de trigo & 21.2 \\
\hline Casca de semente de algodão & 18.6 \\
\hline Bagaço de cana-de-açúcar & 17.4 \\
\hline Casca de arroz & 11.4 \\
\hline
\end{tabular}

Durante este tempo várias informações a respeito do furfural foram sendo coletadas e em 1953 Dunlop e Peters [4], publicaram um livro que foi elaborado com o intuito de reunir o conhecimento acumulado na química dos furanos, cuja maior parte estava registrado sob a forma de patentes devido ao seu interesse industrial.
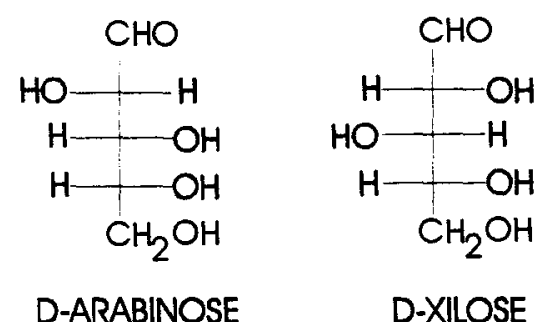

Figura 2.1 - D-Arabinose e D-Xilose, precursores naturais do furfural. 


\section{2-PRODUÇÃO INDUSTRIAL DO FURFURAL}

O furfural, figura 2.2, é obtido a partir da desidratação das pentoses, na maior parte da xilose. A desidratação é uma reação que ocorre com a eliminação de moléculas de água, esta reação acontece mediante fornecimento de energia térmica ao sistema $[4,5,19]$. No caso da produção do furfural o aquecimento direto da massa vegetal não conduz a formação do produto esperado, porém quando é associado à presença de ácidos minerais [5], que atuam como catalisadores, forma-se o furfural. Um mecanismo proposto para explicar a reação de formação baseia-se em um composto intermediário enólico associado à primeira das três etapas do processo, onde todas as etapas envolvem a, eliminação de uma molécula de água [4]. A primeira etapa é uma eliminação simples dando origem ao intermediário, a segunda eliminação acontece em função da ciclização da estrutura e a seguir a última que confere caráter aromático ao sistema $[4,19]$. Outra via baseia-se na tautomerização [15] do intermediário que irá, por desidratação, levar ao mesmo produto final. As rotas sintéticas que explicam a formação do furfural têm em comum a formação do intermediário enólico. Esse intermediário foi identificado posteriormente por técnica espectroscópica [4,41]. Em função das condições reacionais para formação do furfural, meio ácido, as espécies cetônicas ficam favorecidas pela sua estabilidade. Dessa forma na produção do furfural na segunda etapa do mecanismo deve ocorrer à formação de uma cetona e na terceira uma desidratação. 


\section{3-PRODUÇÃO INDUSTRIAL DO ÁLCOOL FURFURÍLICO}

A produção industrial de o álcool furfurílico a partir do furfural está baseada na redução catalítica. Uma série de catalisadores são empregados no processo, alguns são específicos para redução da carbonila outros induzem também a hidrogenação do anel. A reação que conduz ao melhor resultado de formação do álcool acontece quando se utiliza catalisador de cobre metálico [19].

\section{4-PROPRIEDADES DO ÁLCOOL FURFURÍLICO}

O álcool furfurílico, figura (2.2) é um líquido incolor, venenoso $[18,20]$ com cheiro irritante. É solúvel em acetona, álcoois, éter, ésteres, derivados clorados e na maior parte dos solventes orgânicos com exceção dos alcanos [21]. Também é solúvel em água, porém é instável neste meio [4,7]. É um composto muito reativo sendo sensivel à temperatura, oxigênio e a mínima presença de ácido [4,5,7]. É purificado por destilação a pressão reduzida, pois forma mistura azeotrópica com a água o que impede sua purificação por destilação simples [22]. É mantido estável quando guardado em lugar escuro, frio e em presença de uma base orgânica e de um agente dessecante, geralmente emprega-se a n-butilamina para evitar a autoresinificação $[19,23]$.<smiles>OCc1ccco1</smiles><smiles>O=Cc1ccco1</smiles>

Figura 2.2- Molécula de Álcool Furfurilico e de Furfural. 
É um composto bifuncional, isto é, apresenta duas posições ativas quimicamente [1-4]. Reage como álcool primário e sob condições controladas pode ser convertido em derivados funcionais como: éster, derivados halogenados, ácidos e éteres $[1,6,7,19]$. Frente a ácidos reage de forma enérgica $[1,3,5,19]$, dependendo do caráter do ácido em questão, produzindo uma resina de cor marrom escura como produto final $[1,5,24]$. Reduz a solução de permanganato de potássio a frio, se oxida gerando ácido furóico, quando tratado com bromo em meio básico sofre carbonização $[19,20]$. Apresenta aromaticidade, segundo a regra de Hückel representada pela deslocalização eletrônica no seu anel $[5,14,26]$, no entanto, este caráter é menos acentuado com relação aos tióis [14].

O espectro de absorção ótiça apresenta três bandas na região do ultravioleta nos seguintes comprimentos de onda: $209 \mathrm{~nm}, 230 \mathrm{~nm}$ e $270 \mathrm{~nm}$. Na região do visível não apresenta absorção, é um líquido incolor [4]. Já na região do infravermelho surge um conjunto de bandas que quando associadas o identificam. As principais absorções óticas são uma banda larga na região de $3300 \mathrm{~cm}^{-1}$ e outra $2980 \mathrm{~cm}^{-1}$ devido à presença de grupos metilênicos. O núcleo aromático responde com uma absorção através de uma banda estreita em $1501 \mathrm{~cm}^{-1}[4,5]$.

O seu núcleo como é ressonante apresenta as seguintes formas canônicas [19]:

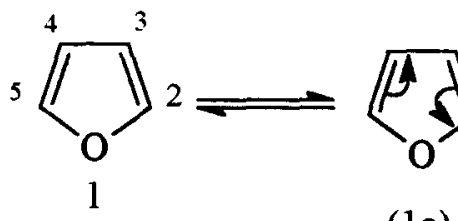

(1a)

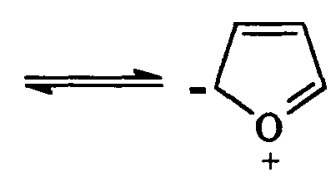

(lb)

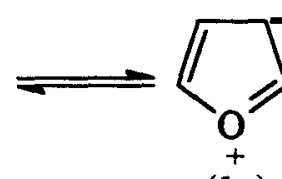

(lc)<smiles>C#CC1C=C[CH+]O1</smiles>

(1d)

Figura 2.3-Estruturas canônicas do anel furânico. 
Baseado nas estruturas ressonantes podemos, figura 2.3, prever como posições mais reativas a 2 e 5 e depois a 3 . As reações de substituição como alquilação e halogenação irão ocorrer preferencialmente nas posições $C_{2}$ e $C_{5}$, quando não estiverem preenchidas. Esses resultados foram comprovados pela estatística da reação quando comparadas estas duas posições.

\section{5-POLIMERIZAÇÃO DO ÁLCOOL FURFURÍLICO}

O álcool furfurílico reage com ácidos para formar polímeros. O processo de catálise do álcool e posterior conversão em polímeros é muito sensível à concentração de ácido, a sua força e a temperatura $[5,7,19,24]$.

O processo de crescimento da cadeia, ou seja, de polimerização é feito através da união sucessiva de unidades furânicas unidas por grupos metilas, seguida da eliminação de moléculas de água [1,2], o ácido não é consumido regenerando-se a cada etapa do processo $[5,19]$. Apesar de não se conhecer detalhadamente o mecanismo de aumento das cadeias, sabe-se que os oligômeros crescem linearmente até um determinado tamanho, figura (2.4), e depois se transformam em resinas termofixas de cor negra $[5,19,24]$. O crescimento inicial das cadeias é acompanhado pela formação de cromóforos e pelo aumento da viscosidade do meio onde se dá a reação [6,23]. A reação de conversão destas cadeias e a forma pela qual as moléculas se entrecruzam, vem sendo estudadas com o intuito de se estabelecer o mecanismo para controle da reação de entrecruzamento [5].

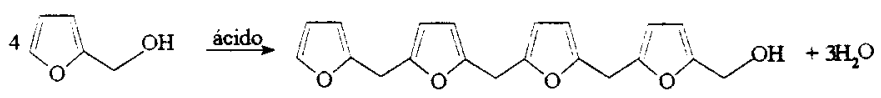

Figura 2.4- Reação de obtenção de polímero do Álcool Furfurílico. 
A polimerização é mediada na maioria dos casos pela presença de um ácido, no entanto, a luz e a temperatura também induzem reação de resinificação [4]. A reação de polimerização se desenvolve em dois estágios principais: o primeiro caracterizado pela formação de oligômeros e o segundo pela formação de ramificações que estão associadas ao processo de entrecruzamento $[1-5,11,23]$.

\subsection{1- FORMAÇÃO DO ÁCIDO LEVULÍNICO}

Uma conseqüência da reação de polimerização do álcool furfurílico é a formação de moléculas de água. O álcool furfurílico é instável em meio aquoso e facilmente convertido em ácido levulínico $[1,4,5,7]$, figura 2.5 . Krishina e Chanda (1974) estudaram a cinética de polimerização do álcool furfurilico em solução aquosa e constataram o aumento da acidez do meio provocada pela conversão do álcool em ácido levulínico em [7]. O mecanismo para conversão do álcool em ácido levulínico sugere a formação de um íon carbônio. Este mecanismo pode ser melhor entendido em etapas [4] 


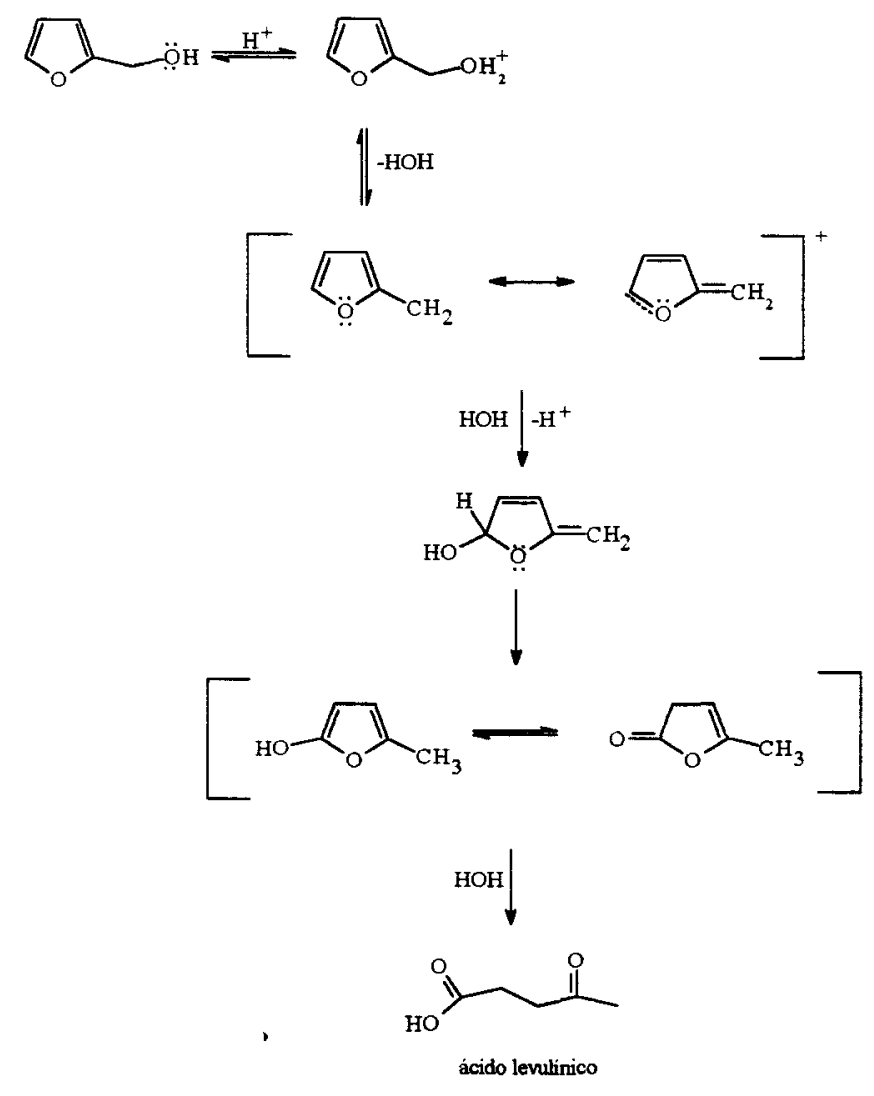

Figura 2.5-Mecanismo de formação do ácido levulínico.

Através deste mecanismo podemos perceber que as moléculas de ácido atuam com um catalisador ao passo que a água participa da reação de conversão. Atribui-se à formação do ácido levulínico o aumento da acidez, isto é, decorrente da instabilidade do anel frente a moléculas de água $[1,7]$, o que demostra a tendência do sistema em formar essas moléculas mais ácidas que o álcool.

\subsection{2- FORMAÇÃO DE ÉTERES}

A formação de éteres (difurfurílico) foi estudada por Gonzalez, Martinez e Ortiz (1992), e é relatada como decorrente do processo de polimerização do álcool furfurílico através da catálise ácida, sendo favorecida sob condições experimentais onde a temperatura é baixa [6,27]. Em seu estudo esses autores analisaram a relação 
entre a formação de estruturas poliméricas e de éteres [27]. Fizeram estudos de ressonância nuclear magnética e perceberam a presença de pontes metilênicas entre os oligômeros $[6,25,25]$. Observaram que este processo guarda uma relação entre a concentração do monômero e a concentração do catalisador e a temperatura. Quando a relação álcool/catalisador é alta há um aumento de estruturas do tipo éter, já o aumento da temperatura diminui a formação de éteres na estrutura. As decomposições dessas pontes de éteres na estrutura foram associadas por alguns autores $[16,17]$ ao processo de entrecruzamento. Considerando que a formação de polímero termofixo é acompanhada por uma grande liberação de calor $[1,3,19]$, a formação de moléculas de éteres ficaria inviabilizada, de modo que não poderiam exercer influência no processo de entrecruzamento.

\section{6-OS OLIGÔMEROS}

O processo de polimerização do álcool furfurílico é acompanhado de uma variação cromática $[1,5,11,19]$. As cores variam, podendo ser observado o amarelo [11], o azul e o verde [10] em uma variedade de tons, atingindo o marrom e finalmente a preto [4,5,24]. Este processo é acompanhado também pelo aumento da viscosidade do meio $[23,30]$. O desenvolvimento das cores conjuntamente com a viscosidade, pode ser atribuído a diversos estágios de polimerização $[1,5]$. O mecanismo pelo qual é formado o cromóforo não é totalmente entendido [5]. Segundo Gandini (1996) a presença de moléculas conjugadas é baseada na retirada de íons de hidreto, gerando uma estrutura do tipo carbocátion, figura (2.6). Essa estrutura em uma etapa posterior pode perder um próton, o que a torna com caráter 
conjugado e assim passível de absorção no visível $[5,6,27]$. O mecanismo proposto não está totalmente elucidado e é passível de algumas dúvidas. Principalmente quando propõem a retirada de íons hidreto sobre a estrutura do oligômero.

Com intuito de estabelecer a base desse mecanismo, Gandini, Belgacem e Choura (1996) realizaram um estudo utilizando moléculas modelos e compostos de alto poder de abstração de hidretos como: $\mathrm{Ph}_{3} \mathrm{C}^{+} \mathrm{AsF}_{6}^{-}$e observaram através de espectroscopia UV-VIS a formação do cromóforo. De posse destes resultados sugeriram o seguinte mecanismo.

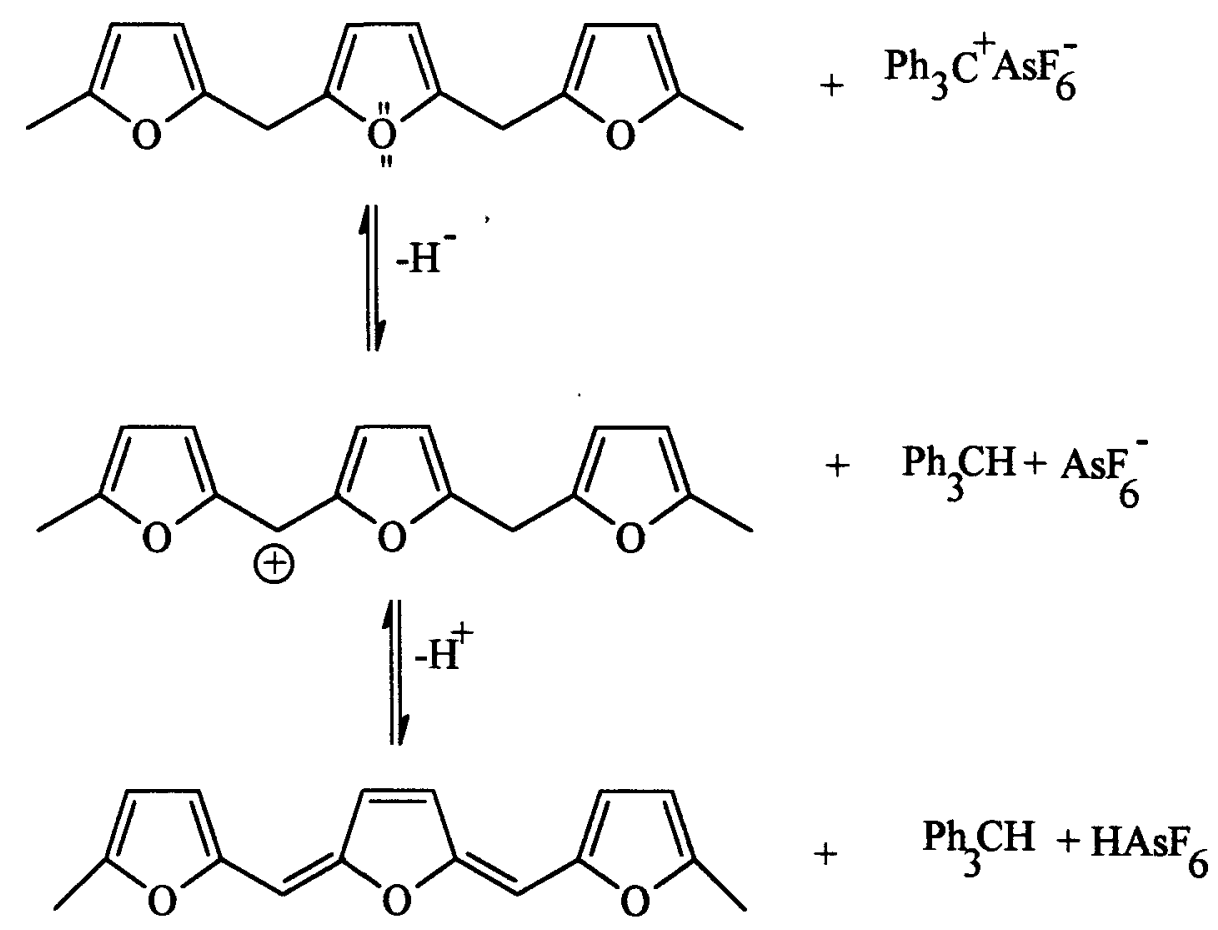

Figura 2.6-Mecanismo proposto por Gandini para formação do cromóforo.

Observaram ainda que quando o sistema era tratado com uma base, os íons carbocátions deixavam de existir formando um produto neutro $[5,6]$ de cor amarelada. Com isto procurou mostrar a presença desse radical no processo de formação de conjugação de suas moléculas modelo. 


\section{7-FORMAÇÃO DO ENTRECRUZAMENTO}

O álcool furfurílico quando catalisado com ácido forte forma resinas de cor marrom escura e viscosa [5]. Estas resinas convertem-se com o tempo em um material termofixo, que caracteriza-se pelo entrecruzamento das cadeia dos polímeros do álcool furfurílico $[1-6,11,19]$. O mecanismo pelo qual as cadeias se entrecruzam ainda não é conhecido, existindo uma grande discussão sobre o assunto [5]. O entendimento do mecanismo de formação das reações laterais e de entrecruzamento nos polímeros do álcool furfurílico é de grande interesse, uma vez que poderá permitir o controle da formação de cadeias condutoras longas.

Wewerka [25], postulou que o entrecruzamento para formação de resinas termofixas acontece pelas posições 3 e 4 do núcleo aromático. No entanto, as análises efetuadas posteriormente comprovaram que as posições previstas como reativas, não contribuem para formação das ramificações devido a baixa reatividade desses carbonos [4,19]. Maciel (1984) [25], investigando os polímeros através de ressonância magnética nuclear de próton verificou a formação de ramificação nas posições metilênicas, figura (2.7). Analisando o modelo proposto por Wewerka, podemos observar que os carbonos 3 e 4 do anel furânico tem uma reatividade mais baixa, em relação ao carbono da ponte metilênica. Este fato pode ser atribuido a uma soma de dois fatores. O primeiro fator está relacionado com a aromaticidade do anel furânico que se apresenta como um sistema ressonante. Um átomo para reagir por substituição precisará interagir com uma densidade de carga, que neste caso é maior sobre as posições 2 e 5 , quando as mesmas não estão ocupadas. $O$ segundo é o efeito induzido pelo núcleo furânico sobre o carbono da ponte metilênica, removendo 
elétrons e deixando este carbono com um caráter ácido mais intenso, portanto mais reativo. Facilitando assim uma reação lateral, que irá provocar um entrecruzamento das cadeias resultando em uma resina termofixa.

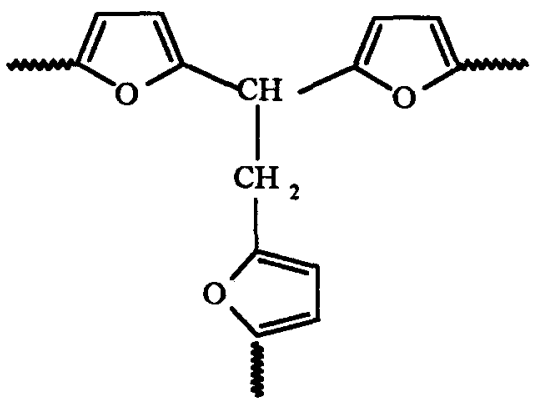

Figura 2.7-Ramificaçðes na estrutura dos oligômeros. Um dos modelos baseia-se na ramificação através dos grupos metilênicos presentes na molécula. Essas reações induzem o crescimento desordenado do polímero, tornando-o termofixo.

Alguns modelos tem sido, propostos com o intuito de explicar os efeitos decorrentes da catálise, visando a formação de cadeias maiores. Gandini e Choura (1996) desenvolveram recentemente um modelo, utilizando compostos semelhantes ao álcool furfurílico e observaram que os entrecruzamentos não ocorrem nos grupos metilênicos, que unem os anéis furânicos [5]. Este fato apresenta uma nova abordagem na forma de explicação do entrecruzamento, pois analisa a formação de estruturas através de reação de Diels-Alder, figura (2.8).
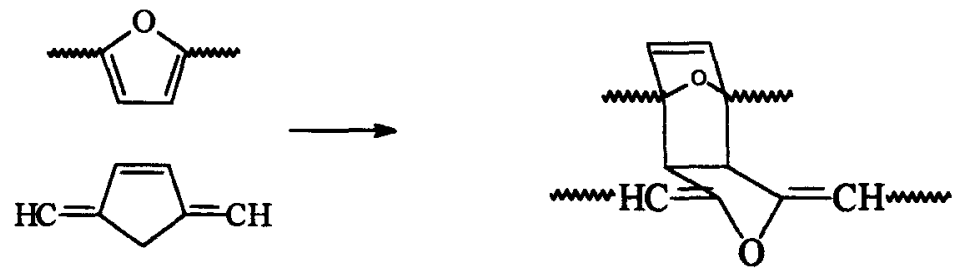

Figura 2.8-Formação de um Diels-Alder- Uma nova proposta na explicação na formação dos polímeros termofixo que está associado com reaçðes entre anéis furânicos. 


\section{8-COMPÓSITOS DE ÁLCOOL FURFURÍLICO E SÍLICA}

Diferentes métodos têm sido empregados para a produção de resinas, alguns visando a produção de materiais compósitos. Spange e Heublein (1992) recobriram superficies de sílica com resinas termofixas do álcool furfurílico. Valeram-se para isso das propriedades superficiais das partículas de silica, que apresentam radicais ácidos, para estudar a interação e a conversão de monômero em polímeros através da ação catalítica de superficie das partículas de sílica [11], figura 2.9. Neste estudo observaram a formação de uma coloração amarela desenvolvida logo no contato entre o álcool furfurílico e a sílica. Esses autores observaram um deslocamento batocrômico intenso de acordo com a relação sílica/AF. Os resultados encontrados sugerem a formação de uma ligação Si-O-C, efetuada na superfície da sílica com o álcool furfurílico, o que foi evidenciado pelo surgimento de uma banda em $964 \mathrm{~cm}^{-1}$ e o desaparecimento da absorção em $3740 \mathrm{~cm}^{-1}$ que é referente ao grupo silanol, para isso foi usada técnica de infravermelho para acompanhamento da evolução da reação. Com a espectroscopia UV-Visível observaram a presença de bandas em $360 \mathrm{~nm}$, entre $480 \mathrm{~nm}$ e $500 \mathrm{~nm}$ e em $600 \mathrm{~nm}$, diferenciando-se da reação de polimerização induzida por ácidos de Lewis, neste caso o produto gerado possui cor marrom que apresenta absorção em 230nm, 348nm e 360nm [24]. 


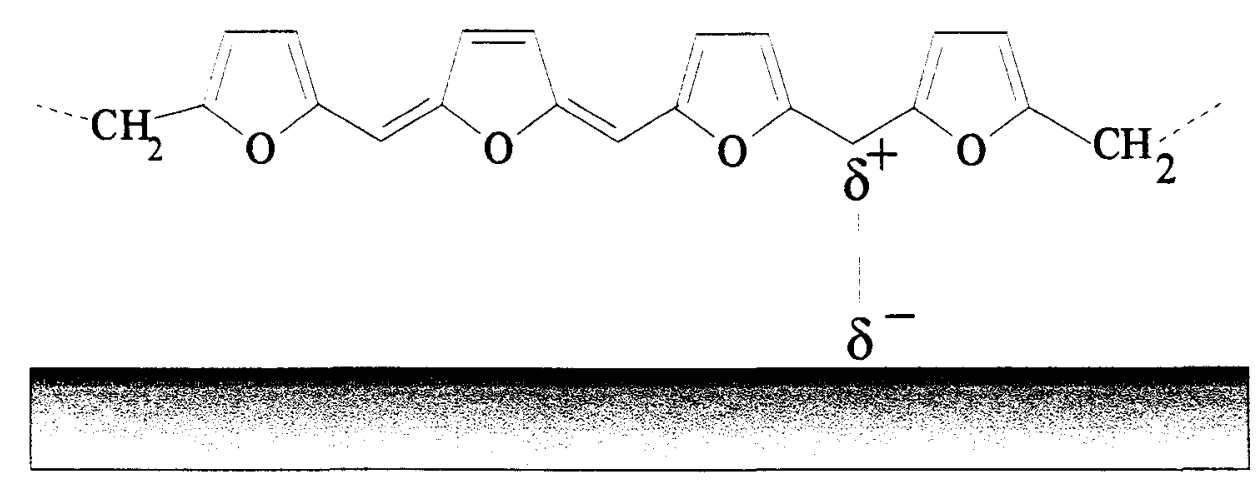

Figura 2.9-Interação de um oligômero com a sílica. Essa interação dá-se através das moléculas de $\mathrm{OH}$ livres presentes no vidro e o carbocátion gerado na molécula de oligômero [11].

\section{9-ORGANIZAÇÃO MOLECULAR}

Alguns sistemas organizam-se em estruturas complexas cujo tamanho excede em algumas ordens de grandeza o seu tamanho molecular [33], gerando uma nova classe de materiais com propriedades diferenciadas. As propriedades dessas estruturas podem gerar novas possibilidades no campo tecnológico $[33,38]$.

Nestes novos materiais o fator superficie é de extrema importância, pois determina a forma e o comportamento desses materiais frente ao meio. Entende-se como sendo superfície a região onde dois materiais coexistem e interface a região que os separa [33,34]. Existem alguns tipos de organizações, bem estabelecidas: micelas, vesículas, micro-emulsões e os filmes de Lagmuir-Blodgett.

As micelas, figura (2.10), são estruturas obtidas quando moléculas anfifilicas, ou seja, moléculas que contém uma parte polar (cabeça), que geralmente é um grupo de ácido carboxílico ou um sal de ácido, e uma outra apolar (rabo) constituída de hidrocarbonetos, que estão presentes na mesma molécula. Estas moléculas quando dispostas em um meio polar tendem a esconder a parte apolar das interações 
com o solvente, expondo somente a parte polar para o meio. $\mathrm{Na}$ micela as moléculas que contribuem para a sua formação não estão unidas por ligações covalentes, a força que as mantém unidas são de natureza hidrofóbica presentes na parte apolar. Tais interações são sensíveis à temperatura.

A estabilidade das micelas é conferida pelo seu raio médio de curvatura. Quando o raio se aproxima do tamanho de molécula estruturas como as micelas são favorecidas, porém quando este valor se torna menor, estruturas do tipo vesículas, figura 2.11, são mais favorecidas [33].

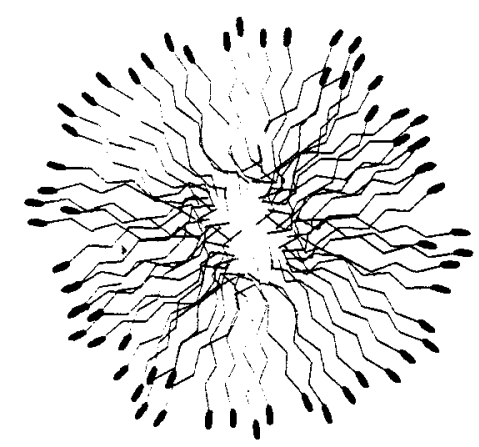

Figura 2.10-Representação esquemática de uma micela, onde as partes polares estão voltadas para o exterior e a parte apolar protegida, quando estão em um meio polar.

As vesículas constituem-se de duas camadas que estão separando duas regiões do mesmo líquido. Em função da sua organização umas séries de aplicações industriais são possíveis com este tipo de estruturas. Algumas das aplicações são: catalisadores, agentes de limpeza, encapsulamento de drogas e micro-ambiente para reações especiais. Para isso uma série de trabalhos tem sido feita para relacionar o método, a forma e o tamanho, com propriedades especificas [33-35]. 


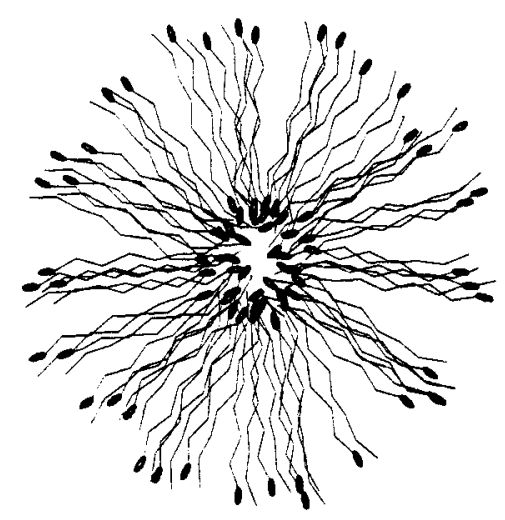

Figura 2.11-Representação de uma vesícula. As vesículas são constituídas de três camadas. A mais externa polar, a intermediária apolar e a mais interna polar, conforme mostra a figura. A estrutura interna constitui-se em um micro-ambiente polar.

As vesículas formam-se espontaneamente através da mistura simples de moléculas anfifilicas, aparecem ainda em sistemas vivos, e têm sido muito estudadas com o intuito de se estabelecer o transporte intra-membranar [37].

As micro-emulsões, figura 2.12 , são ambientes formados a partir de três substâncias distintas. Uma substância polar, uma apolar e uma anfifilica. A estrutura que se forma gera uma correlação macroscópica com os constituintes. Este sistema tem a função de organizar as moléculas cujas interações com o meio foram desfavorecidas, minimizando estas interações desfavoráveis e colocando a molécula "estranha" em uma região cujas interações sejam mais propícias.

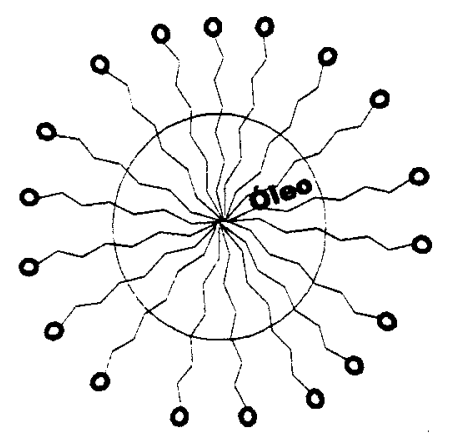

Figura 2.12- Representação de uma micro-emulsão. Onde aparte apolar da substância está imerso em uma artícula apolar, como uma gota de óleo em água. 


\subsection{1-FILMES DE LANGMUIR-BLODEGETT}

Filmes de Langmuir-Blodgett são estruturas peliculares que são depositadas sobre placas, figura (2.13) normalmente de vidro onde as interações com o substrato servem para orientar as moléculas. Para fazer os filmes de Langmuir as placas são mergulhadas em uma solução que contém o material do filme a se formar, assim as moléculas ficam aderidas a superfície fazendo um depósito organizado. Pode-se produzir através deste processo multicamadas de filmes automontados, sua regularidade podendo ser investigada por interferômetria, difração de elétrons e espectroscopia de infravermelho $[39,40]$.

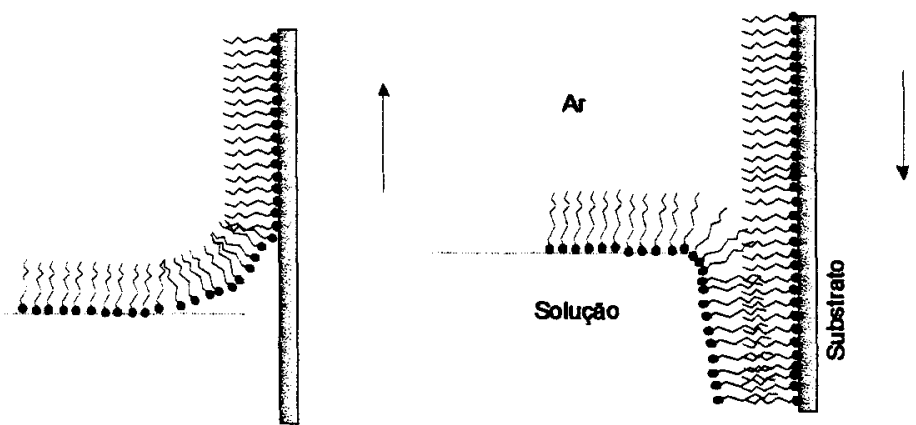

Figura 2.13-Representação esquemática da formação de filmes de Languimuir-Blodgett, sobre placas de vidro. Estes filmes são formados a partir de uma solução diluída do polímero. 


\section{3-METODOLOGIA}

Nesse capitulo serão descritos os procedimentos experimentais usados. 0 conjunto de técnicas empregadas permitiu o estudo do álcool furfurilico e a produção e a análise dos seus oligômeros especialmente dos estágios iniciais dessa reação de polimerização.

Foram usadas as seguintẹs técnicas de identificação: espectroscopia de infravermelho, ressonância magnética nuclear de carbono 13 e de hidrogênio, espectroscopia de UV-Visível, cromatografia gasosa, cromatografia de coluna e espectroscopia de massa.

Para estudar a reação de polimerização foram usados tubos capilares de borosilicato de diversos diâmetros, figura 3.4. Uma outra forma de promover a reação foi através do borbulhamento, no álcool furfurílico, dos vapores de ácido clorídrico provenientes da passagem de $\mathrm{N}_{2}$ gás em uma solução de ácido clorídrico em água. 


\section{1-PURIFICAÇÃO DO ÁLCOOL FURFURÍLICO}

O álcool furfurílico é um líquido incolor. No entanto, o álcool furfurílico (Reagente Fluka-P.A) adquirido encontrava-se com a cor amarela. Para promover a purificação do álcool foi realizada uma destilação a pressão reduzida [22].

A destilação a pressão reduzida, figura 3.1, apresenta-se mais eficiente para purificação do álcool, pois consegue alterar para valores mais baixos, a temperatura de ebulição dos compostos. No álcool furfurílico isso é de extrema importância, pois evita o processo de polimerização induzida por calor.

O ponto de ebulição do álcool furfurílico é $178^{\circ} \mathrm{C}$. Quando o álcool foi destilado a pressão reduzida à temp’eratura de ebulição foi $92^{\circ} \mathrm{C}$. $\mathrm{O}$ álcool destilado foi tratado com sulfato de cálcio anidro (Reagente Sinty-P.A), para retirar moléculas de água.

Após a destilação o álcool furfurílico foi caracterizado e para isso foram usadas técnicas magnéticas, ópticas e cromatográficas.

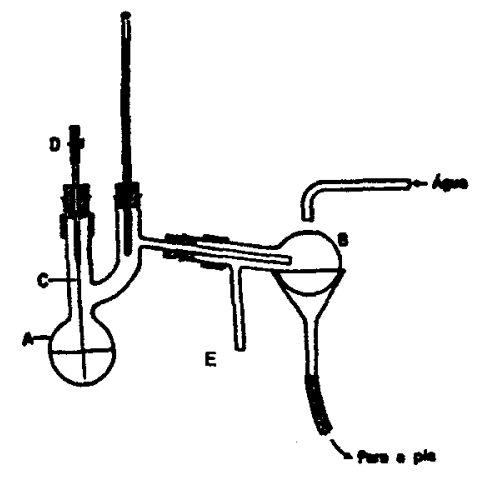

Figura 3.1- Esquema da aparelhagem de destilação do álcool furfurílico. Aonde A é o balão com saída de Claisen, B é um balão de destilação normal, C é um tubo capilar de segurança, D é um estrangulador e E é a saída para a bomba de vácuo. 


\section{2-ANÁLISE DO ÁLCOOL FURFURÍLICO}

Para verificar a eficiência do processo de purificação do álcool furfurílico, foram feitas análises que tiveram o intuito de estabelecer a pureza desse produto e a sua estrutura química.

\subsection{1-ESPECTROSCOPIA DE INFRAVERMELHO}

As medidas de espectroscopia no infravermelho foram realizadas utilizandose um espectrofotômetro BOMEN MB-102 com FTIR. Primeiramente foi pesado 500mg de brometo de Potássio (KBr-ALDRICH) anidro. Esse sal foi prensado, resultando em uma pastilha translúcida. A essa pastilha foram adicionadas duas gotas (aproximadamente $0,1 \mathrm{ml}$ ) de álcool furfurílico recém destilado. Feito isso, a pastilha foi imediatamente colocada no porta amostra e tomado seu espectro.

\subsection{2-ESPECTROSCOPIA DE RESSONÂNCIA MAGNÉTICA DE CARBONO E HIDROGÊNIO.}

Para as análises de Ressonância Magnética Nuclear foi usado o equipamento BRUCKER UX-200. Foram usadas 2 gotas $(0.1 \mathrm{ml})$ de álcool furfurilico recém destilado, que foi dissolvido em clorofórmio deuterado e posto em um tubo de quartzo para a análise. Os espectros obtidos encontram-se, com a integração fornecendo sua área e a multiplicidade dos picos. 


\subsection{3-DETECÇÃO DA FLUORESCÊNCIA.}

A fluorescência do AF puro foi observada acidentalmente em um dos desenvolvimentos deste trabalho. Para detecção desse efeito foi usado um laser de argônio, cujo comprimento de onda escolhido para excitação foi de $514 \mathrm{~nm}$. A potência do laser incidente sobre um cubeta de caminho ótico $2.0 \mathrm{~mm}$, foi variada de $80 \mathrm{~mW} \mathrm{a} 600 \mathrm{mw}$, gerando uma fluorescência na amostra. O sinal de fluorescência foi medido usando-se uma fotomultiplicadora.

\subsection{4-TÉCNICAS CROMATOGRÁFICAS}

A cromatografia é uma técnica de separação e de determinação de compostos. Ela está fundamentada na velocidade relativa desse compostos em relação a uma fase estacionária. Existem várias maneiras de promover essa separação em função desse princípio. Foram usadas nesse trabalho: cromatografia em camada delgada, cromatografia de coluna e cromatografia gasosa.

\subsubsection{1-CROMATOGRAFIA EM CAMADA DELGADA (TLC)}

É técnica extremamente simples e baseia-se no deslocamento diferenciado dos compostos sobre uma superficie delgada de um material adsorvente, no caso sílica. É muito útil na observação do número de compostos, pois cada composto apresenta um tempo de retenção, TR. Para isso foi preparada uma solução de hexano/acetona 80/20 (v/v) que serviu de fase móvel. Essa solução foi colocada dentro de uma cuba, juntamente com uma placa cromatográfica. Por capilaridade, a 
fase móvel promove uma migração diferenciada dos componentes da amostra sobre a placa, sendo possível separa-los. Após realizada corrida da fase móvel, foi borrifado na placa uma solução de ninidrina em $\mathrm{HCl}$, e posta sobre uma placa de aquecimento a $100^{\circ} \mathrm{C}$ para revelar os produtos.

\subsubsection{2-CROMATOGRAFIA DE COLUNA}

Essa técnica foi usada com o intuito de se obter em maior concentração o produto presente no álcool furfurilico que ainda não havia sido detectado por RMN e infravermelho.

A coluna cromatográfica fọi preparada usando-se uma coluna de vidro de $60 \mathrm{~cm}$ de altura com $3 \mathrm{~cm}$ de diâmetro. $\mathrm{Na}$ extremidade inferior da coluna foi colocado um pedaço de lã-de-vidro, e em seguida foi preenchida com sílica (produto ALDRICH) e uma mistura de hexano e acetona na proporção de 80/20 (v/v). O extrato obtido da destilação a pressão reduzida do álcool furfurilico foi passado através dessa coluna cromatográfica. Após 20minutos, aproximadamente, começaram a ser detectados produtos provenientes da separação. Nesse instante iniciou-se o recolhimento das frações, cerca de $20 \mathrm{ml}$, e através de TLC foi acompanhado o surgimento dos compostos em função do seu tempo de retenção na coluna 


\subsubsection{3-CROMATOGRAFIA GASOSA (CG)}

As medidas foram realizadas usando-se um aparelho SHIMADZU GC-17A, na configuração experimental mostrada na tabela 2 tendo como finalidade acompanhar a concentração relativa dos compostos presentes nas soluções.

Tabela 2-Condições experimentais usadas para a análise cromatográfica

\begin{tabular}{|c|c|}
\hline Gás de Arraste & Hidrogênio \\
\hline Temperatura do Injetor & $80^{\circ} \mathrm{C}$ \\
\hline Temperatura da Coluna & $200^{\circ} \mathrm{C}$ \\
\hline Detector & Condutividade Térmica \\
\hline Coluna & DB1 (apolar) \\
\hline
\end{tabular}

Nessa configuração foram feitos os testes de pureza do álcool furfurilico, tabela 3. Foi injetado $0.1 \mathrm{ml}$ de álcool furfurílico no cromatógrafo, a análise da solução amarela e a análise das frações extraídas a partir da separação foram feitas usando uma coluna cromatográfica de sílica tabelas 4-7. $O$ espectro de massa foi obtido usando o equipamento o cromatógrafo acoplado ao espectrômetro de massa SHIMADZU modelo GC-MS QP5000. 


\section{3-DETERMINAÇĀO DA VELOCIDADE LIMITE EM CAPILARES VERTICAIS}

O álcool furfurílico, FA, foi introduzido dentro de tubos capilares (Produto SCHOTT) em forma de "U", através de uma pipeta Pasteur. A introdução do AF foi feita a partir de uma das extremidades do tubo, evitou-se que durante o preenchimento do capilar em "U" o AF atingisse a topo do capilar na outra extremidade. Os diâmetros internos dos capilares usados foram: $0.4 \mathrm{~mm}, 0.6 \mathrm{~mm}$, $0.8 \mathrm{~mm}, 1.2 \mathrm{~mm}, 1.4 \mathrm{~mm}, 1.7 \mathrm{~mm}, 2.2 \mathrm{~mm}, 2.7 \mathrm{~mm}$ e $5.0 \mathrm{~mm}$ e $10 \mathrm{~cm}$ de comprimento. Esses tubos capilares, cada um a sua vez, foram colocados em uma câmara com vapores ácidos.

Para confecção da câmara ácida foi usado um tubo de vidro com $40 \mathrm{~cm}$ de altura e $4 \mathrm{~cm}$ de diâmetro. Nesse cilindro foi adicionado $10 \mathrm{ml}$ de ácido clorídrico $12 \mathrm{~N}$ e em seguida foi adicionado um sistema contendo, o tubo capilar em "U", uma escala milimétrica e um termômetro que estava preso a uma rolha revestida de Teflon, figura 3.2. Assim o vapor gerado pela solução de ácido clorídrico, passa a ocupar todo o volume da câmara, após seu fechamento.

O deslocamento da frente foi observado com auxílio de uma lente biconvexa $(\mathrm{df}=10 \mathrm{~cm})$. Foi usado um cronômetro para avaliação do deslocamento da frente no capilar com relação ao tempo. Este procedimento foi realizado para determinação da velocidade limite para os diversos raios de capilares. 


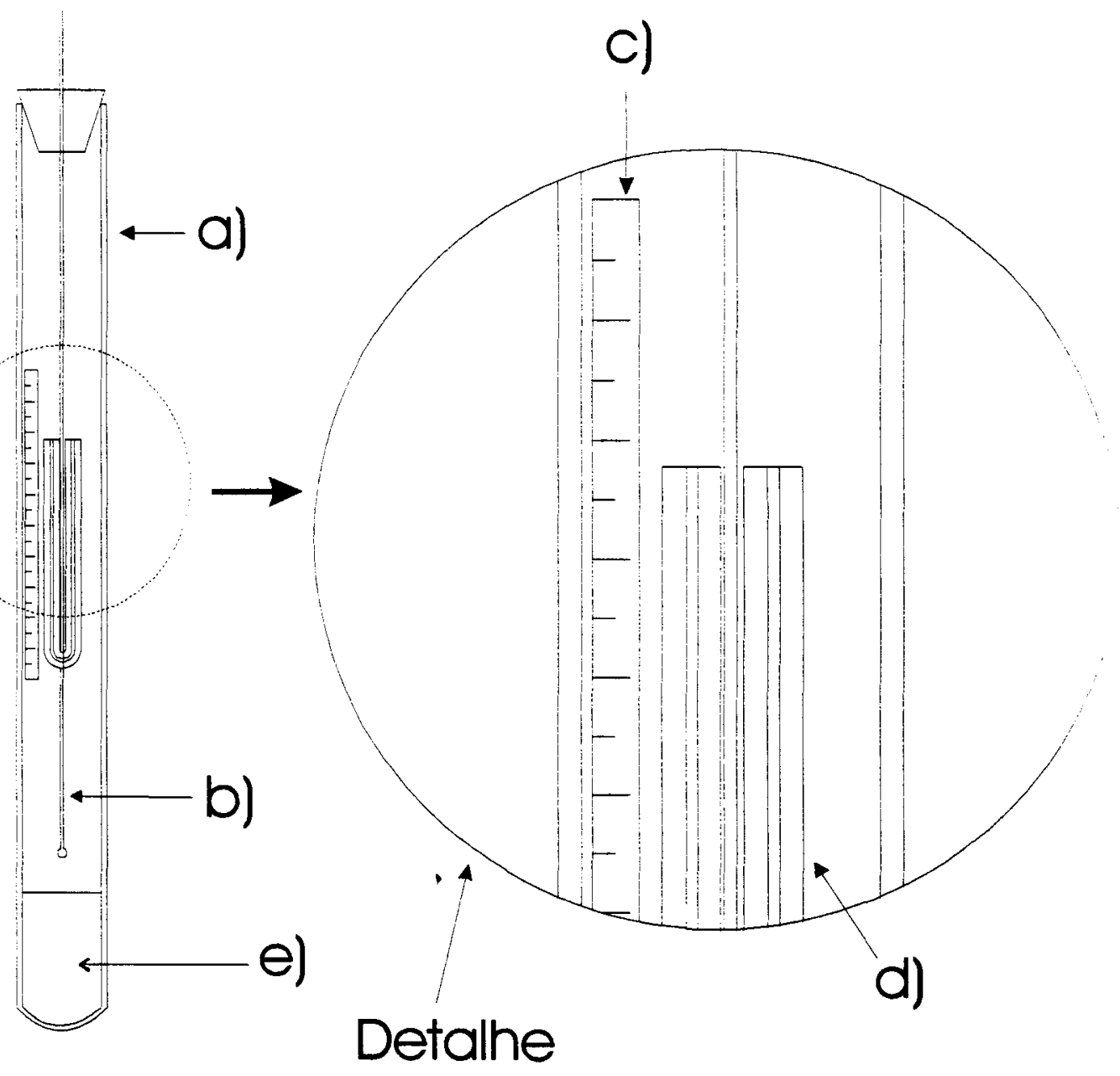

Figura 3.2-Esquema de determinação do deslocamento da frente com o tempo. a) Câmara ácida. b) termômetro. c) Escala milímetrica. d) Tubo capilar em "U". e) Solução de HCl 12N. 


\section{4-DERTERMINAÇÃO DA VELOCIDADE LIMITE EM CAPILARES HORIZONTAIS.}

Este método é bastante semelhante ao descrito anteriormente, as alterações estão relacionadas somente com a forma do tubo capilar. Com intenção de avaliar a progressão da frente de deslocamento horizontalmente, foi idealizado um sistema como da figura 3.3. As medidas foram feitas usando-se tubos de diâmetro $2.2 \mathrm{~mm}$, na temperatura de $23^{\circ} \mathrm{C}$. Estes tubos foram expostos aos vapores do ácido clorídrico, como mostra a figura (3.3). Sendo o valor do "h" $1.0 \mathrm{~cm}$ e do braço horizontal, chamado de "L" $6.0 \mathrm{~cm}$.

\section{Câmara ácida}

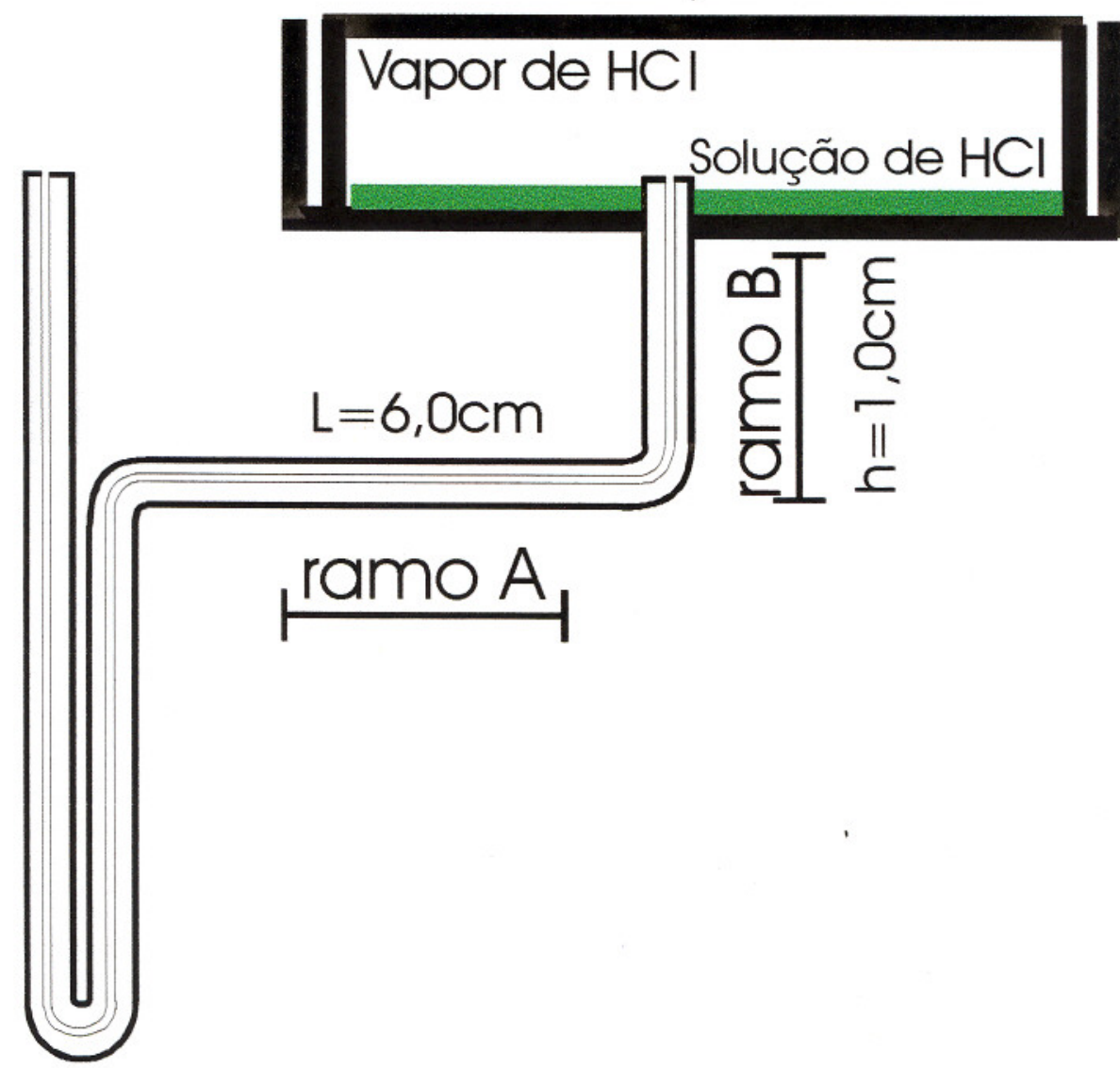

Figura 3.3- Aparelhagem usada para estudar a propagação da frente de cor azul nos tubos capilares com uma parte na horizontal. 


\section{5-DETERMINAÇÃO DA DENSIDADE DOS OLIGÔMEROS FORMADOS.}

O terceiro experimento consistiu na variação da concentração da solução de álcool furfurílico colocada dentro dos capilares. Para isso foi usado diclorometano, DCM (Reagente MERCK-PA), nas concentrações de $0 \%, 20 \%$, e $48 \%$. Como no esquema da figura 3.2, avaliamos o deslocamento da frente e o seu perfil em relação ao tempo. Para isso usamos o mesmo procedimento experimental da determinação das velocidades limites em capilares em "U". Essas velocidades foram medidas em tubos capilares de $1.7 \mathrm{~mm}$ de diâmetro.

\section{6-PREPARAÇÃO DOS OLIGÔMEROS PARA MEDIDAS ÓPTICAS.}

Os oligômeros foram preparados de duas maneiras distintas. A primeira foi baseada na polimerização através da catálise heterogênea, usando para isso, a interface de álcool-vapor de ácido contido dentro de tubos capilares de borosilicato. Para isso foi montada a aparelhagem experimental da figura 3.4 , com capilares de diferentes raios. Um sistema foi construído com o raio de $0.85 \mathrm{~mm}$ e outro com o raio de $1.1 \mathrm{~mm}$.Na outra o ácido foi borbulhado diretamente dentro do álcool furfurilico.

\subsection{1-CATÁlISE ATRAVÉS DA SUPERFÍCIE DE CAPILARES AO VAPOR DE ÁCIDO.}

A figura 3.4 mostra o dispositivo usado ao qual foi adicionado o AF pelo funil. Com isso foi possível controlar a adição do álcool ao sistema evitando-se que ele chegasse excessivamente próximo a superfície do capilar no ramo que foi exposto a câmara com vapor do ácido, isso, para que não ocorresse molhamento da boca do 
capilar. A superficie do capilar foi exposta a uma câmara que continha ácido clorídrico concentrado $(C=12 N)$, e os vapores provenientes dessa solução foram responsáveis pela catálise do álcool furfurílico na interface com o vapor de ácido. Este procedimento foi repetido igualmente em dois capilares de raios um de $0.85 \mathrm{~mm}$ e o outro de $1.1 \mathrm{~mm}$.

O tempo de exposição aos vapores foi de 5 minutos. Nesse tempo foi gerada uma frente azul, que se formou na interface AF-vapor de ácido e caiu através do tubo capilar, sendo estocada no pequeno balão adaptado situado $3 \mathrm{~cm}$ abaixo da superfície que foi responsável pela estocagem dessa frente. A retirada dessa frente azul estocada foi feita por drenagem. Abrindo-se a válvula $\mathbf{E}$, foi obtida uma solução azul usada para estudar o espectro óptico.

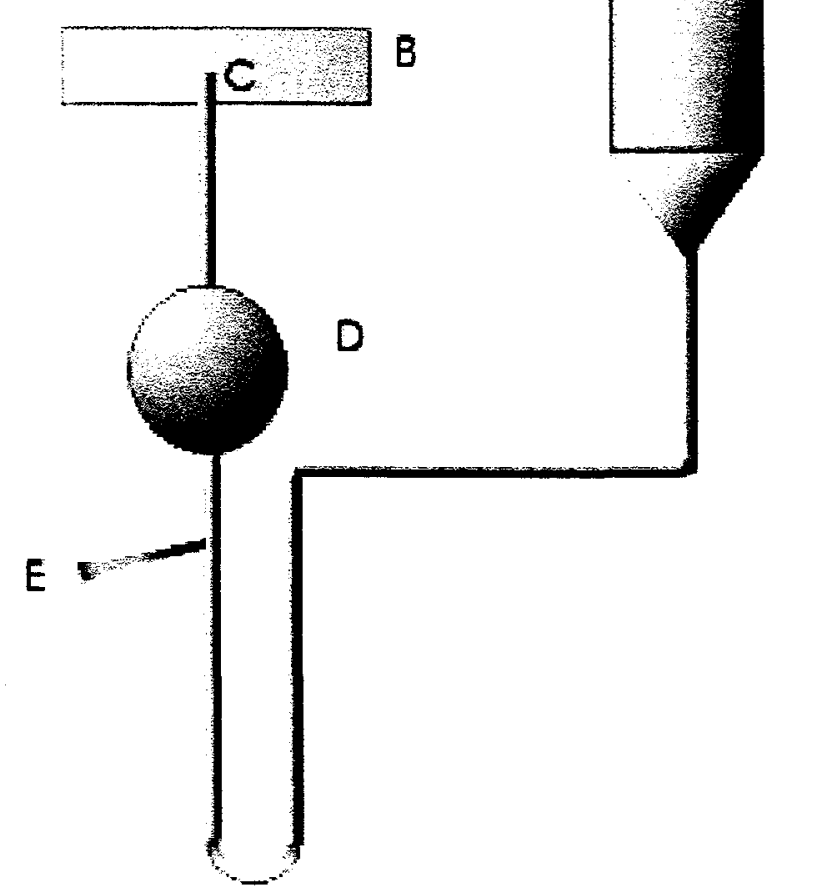

Figura 3.4- Aparelhagem para obtenção da solução de oligômeros do álcool furfurílico. Aonde A é o funil por onde se adiciona o álcool furfurílico, B é uma placa de Petri com um furo no centro e com tampa, aonde foi adicionado $1 \mathrm{ml}$ de ácido cloridrico (câmara ácida, $\mathrm{C}=12 \mathrm{~N}$ ), C ponta do capilar que é inserida na câmara ácida, D é um elemento de volume (cerca de $10 \mathrm{ml}$ ) onde a solução gerada na superficie foi armazenada e E uma válvula de saída com função de drenar o estocado em D. 


\subsection{2-CATÁLISE ATRAVÉS DO BORBULHAMENTO.}

O álcool furfurílico puro foi posto em um becker. A catálise deu-se através do borbulhamento de vapor de uma solução $6 \mathrm{~N}$ de $\mathrm{HCl}$. $\mathrm{O}$ arraste do vapor, foi feito com auxílio de gás nitrogênio seco (Produto-White Martins). Foi usada uma vazão para o gás nitrogênio de $0.1 \mathrm{ml} / \mathrm{s}$, aproximadamente durante 5 minutos. $O$ gás nitrogênio foi borbulhado na solução ácida contida em um frasco lavador de gás e a mistura gasosa resultante borbulhada no AF.

\section{7-ESPECTROSCOPIA DE UV-VIS.}

As medidas óticas foram realizadas em um espectrofotômetro Cary-17a que opera em um intervalo de $200 \mathrm{~nm}$ a $3000 \mathrm{~nm}$. O máximo valor da absorção ótica capaz de ser medido nesse equipamento é 3.0. As medidas da absorção ótica das soluções estudadas foram realizadas com o auxílio de duas cubetas de quartzo com caminho óptico de $10,0 \mathrm{~mm}$. As medidas foram precedidas da tomada da linha de base com as duas cubetas vazias, uma no feixe de medida e outra no feixe de referência.

As medidas da densidade óptica das soluções de oligômeros foram realizadas tendo no feixe de referência uma solução de $\mathrm{AF} / \mathrm{DCM}$ de tal concentração que não houvesse bandas de absorção do monômero no espectro. Essa medida, no entanto, usa álcool furfurílico no feixe de referência, o que provoca para comprimento de onda abaixo de 320nm uma alta absorção desse feixe. Nesse caso o aparelho tenta corrigir essa alta absorção, abrindo a fenda do monocromador. 
Para normalizar os espectros obtidos, eles foram divididos pela sua absorção máxima. Nesse caso, o valor da absorção no comprimento de onda $345 \mathrm{~nm}$ será sempre igual a 1 para a análise do espectro. 


\section{4-RESULTADOS E DISCUSSÃO}

\section{1-ANÁLISE DO ÁLCOOL FURFURÍLICO}

O álcool furfurílico é um composto incolor [4,5], cujas bandas de absorção estão na região do ultravioleta [4]. Seu espectro de absorção UV-VIS, mostra um máximo proeminente em $270 \mathrm{~nm}$, figura 4.1 . No espectro de transmissão no infravermelho, figura 4.2, destacam-se algumas bandas. Uma banda larga em 3349 $\mathrm{cm}^{-1}$, associada com o estiramento do grupo $\mathrm{OH}$. As duas bandas geminadas: uma em $2929 \mathrm{~cm}^{-1}$ e outra em $2972 \mathrm{~cm}^{-1}$, são referentes ao estiramento dos grupamentos metilas alifáticos. Um pico estreito em $1504 \mathrm{~cm}^{-1}$ referente a absorção do núcleo aromático, um pequeno pico em $1627 \mathrm{~cm}^{-1}$ atribuído ao estiramento das ligações carbono-carbono do anel e um pico intenso em $1008.43 \mathrm{~cm}^{-1}$ relacionado com o estiramento assimétrico da ligação C-O do álcool ligado ao anel aromático além de outras bandas estreitas em freqüências menores. Através do espectro de ressonância magnética nuclear de carbono 13 , figura 4.3 , pode observar a presença de cinco picos expressivos. Um pico intenso em $57 \mathrm{ppm}$ relacionado com a metila ligada ao anel. Um triplete muito pouco intenso com centro em $77 \mathrm{ppm}$ que é do solvente. Outro pico em 107.6ppm, e muito próximo a ele, um outro em $110.23 \mathrm{ppm}$ relativos aos carbonos das posições 3 e 4 do anel furânico respectivamente. Outro em 142,38ppm referente ao carbono da posição 5 e um último pico em $153.9 \mathrm{ppm}$ referente ao 
carbono da posição 2, ambos do anel furânico. Analisando o espectro de ressonância magnética de prótons, figura 4.4 podemos observar a presença de cinco picos expressivos, a saber: O primeiro, pouco intenso, na forma de singlete em $2.9 \mathrm{ppm}$ referente ao próton da hidroxila, o segundo também na forma de singlete em $4,53 \mathrm{ppm}$ relacionado com os prótons sobre a metila que está ligada ao anel. $\mathrm{O}$ terceiro e o quarto aparecem como um duplo dubleto na faixa de $6.2 \mathrm{ppm}$ a $6.3 \mathrm{ppm}$ atribuídos aos hidrogênios das posições 3 e 4 . O último, um singleto em $7.26 \mathrm{ppm}$ referente ao hidrogênio da posição 5. Analisando a multiplicidade dos sinais, chegamos à distribuição de prótons que constituem a molécula do álcool furfurílico.

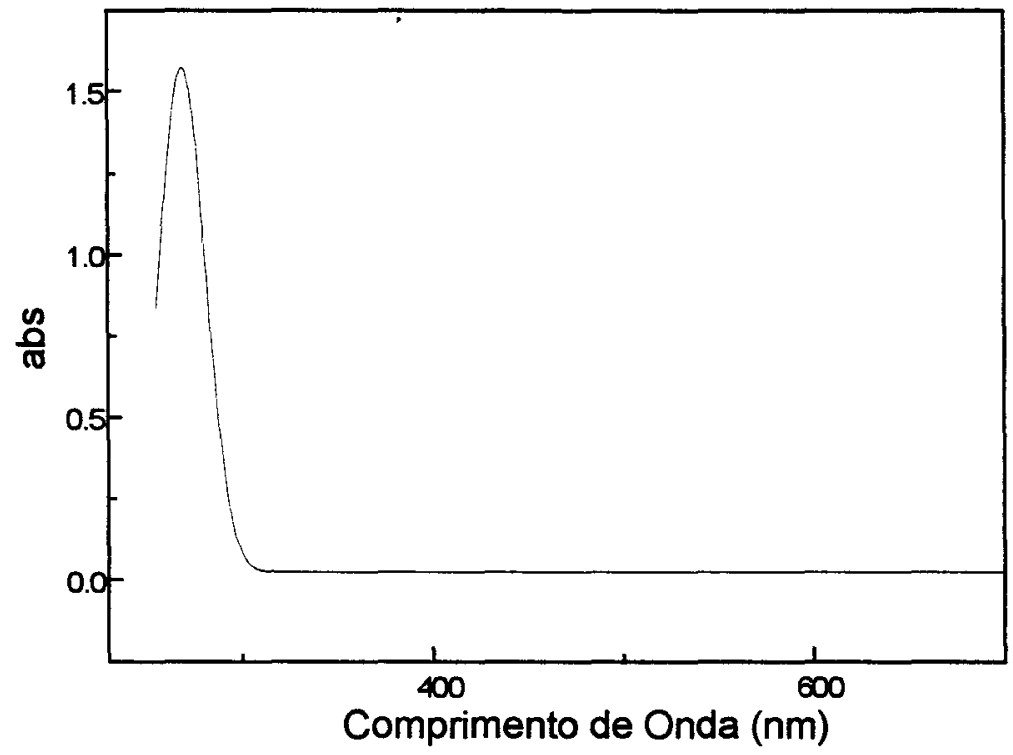

Figura 4.1-Espectro de Absorção ótica UV-VIS do Álcool Furfurílico, $\lambda_{\max }=270 \mathrm{~nm}$. Medido em cubeta de quartzo com o caminho óptico de $10 \mathrm{~mm}$. Concentração aproximada da solução $0.01 \% \mathrm{v} / \mathrm{v}$ de AF em DCM. 


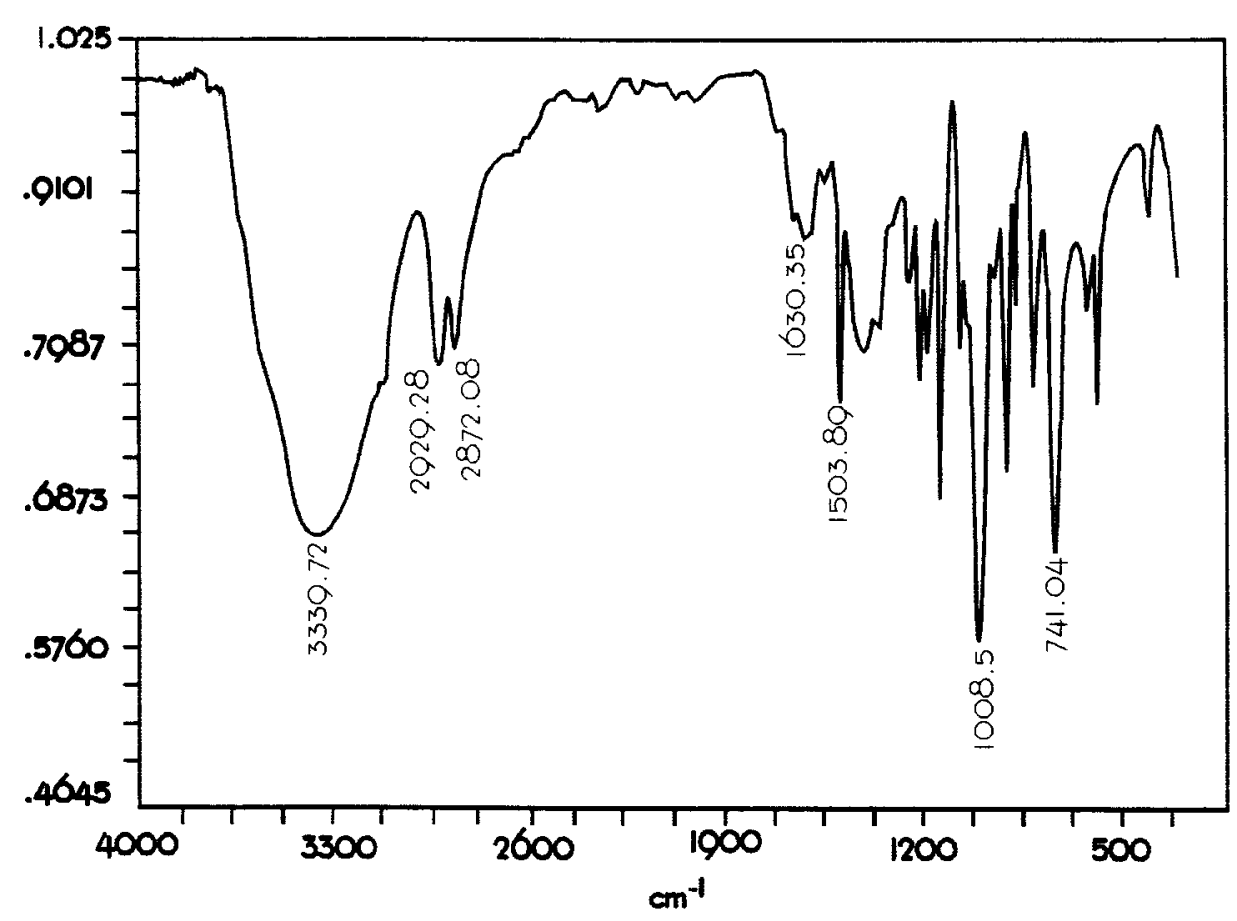

Figura 4.2-Espectro de Transmissão no infravermelho do Álcool Furfurílico recém destilado medido em uma pastilha de $\mathrm{KBr}$.

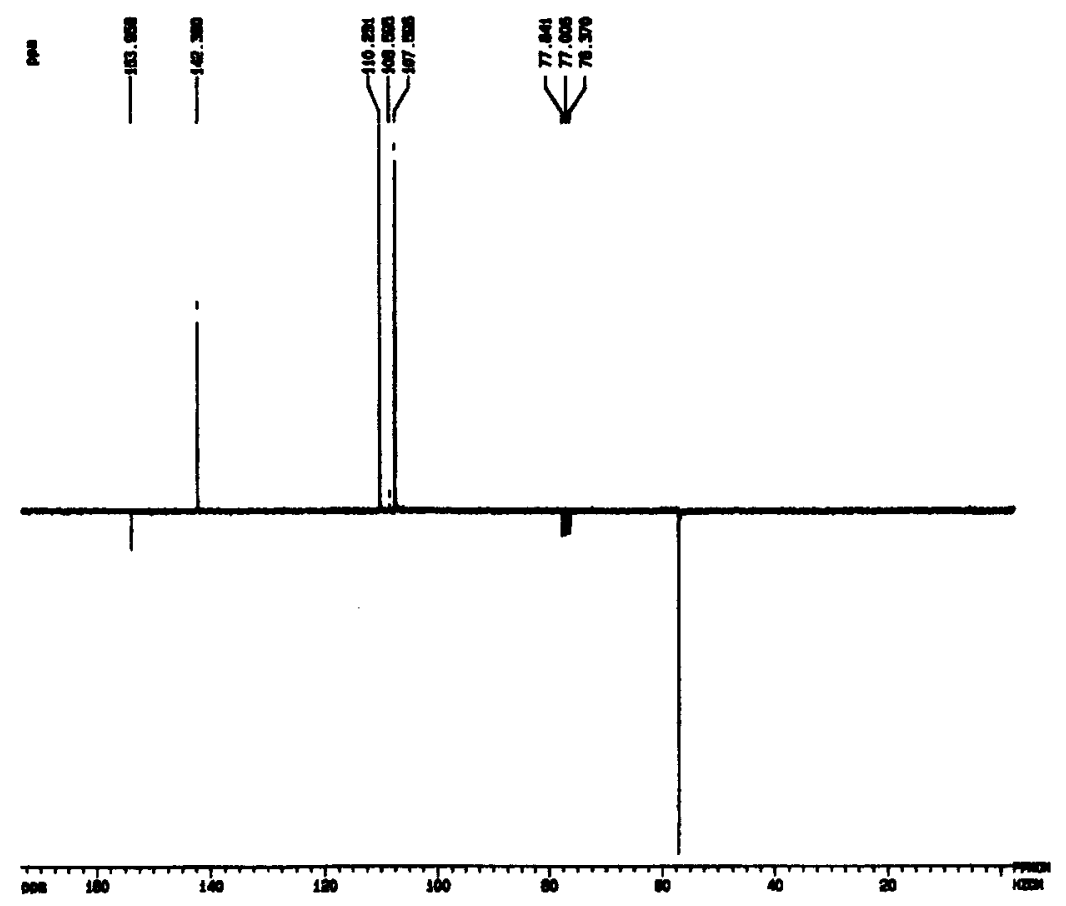

Figura 4.3-Espectro Pendant de Ressonância Magnética de Carbono do Álcool Furfurílico incolor, tomado a partir de uma solução em $\mathrm{CDCl}_{3}$. 


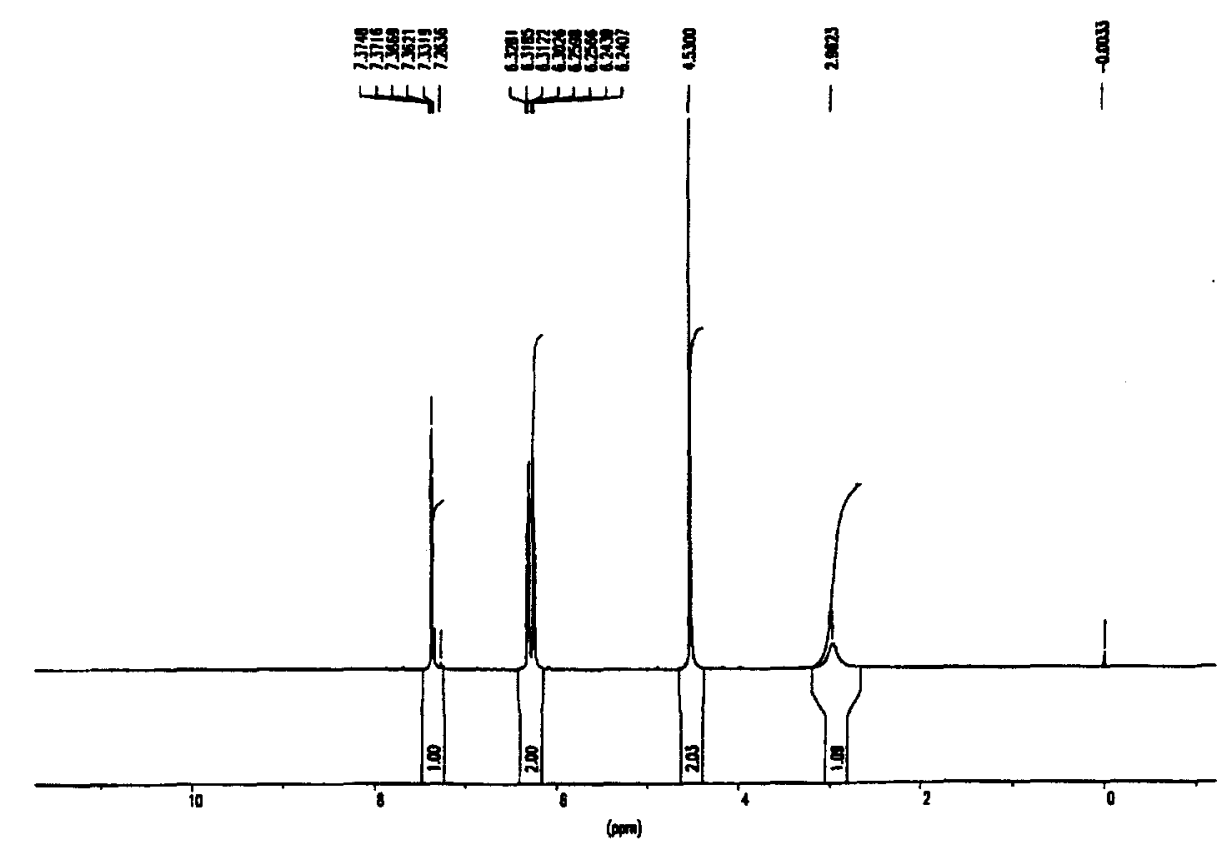

Figura 4.4-Espectro de Ressonância magnética de prótons do Álcool Furfurílico incolor usando como solvente $\mathrm{CDCl}_{3}$.

O AF quando exposto a luz de um laser CW $(\lambda=514 \mathrm{~nm})$, apresentou fluorescência. A fluorescência é um fenômeno que está baseado na absorção e subseqüente emissão de fótons. $\mathrm{O}$ AF empregado nesse experimento apresenta-se puro quanto às análises de absorção ótica, UV-VIS, IR e Ressonância Magnética Nuclear, pois não são identificadas bandas nos espectros acima. Para verificar a possibilidade de ter sido originada a absorção de dois fótons e em função disso o surgimento da fluorescência, conduzimos um experimento variando a potência do laser. A potência da luminescência apresentou dependência linear, figura 4.5, descartando assim o efeito não linear na absorção de dois fótons. 


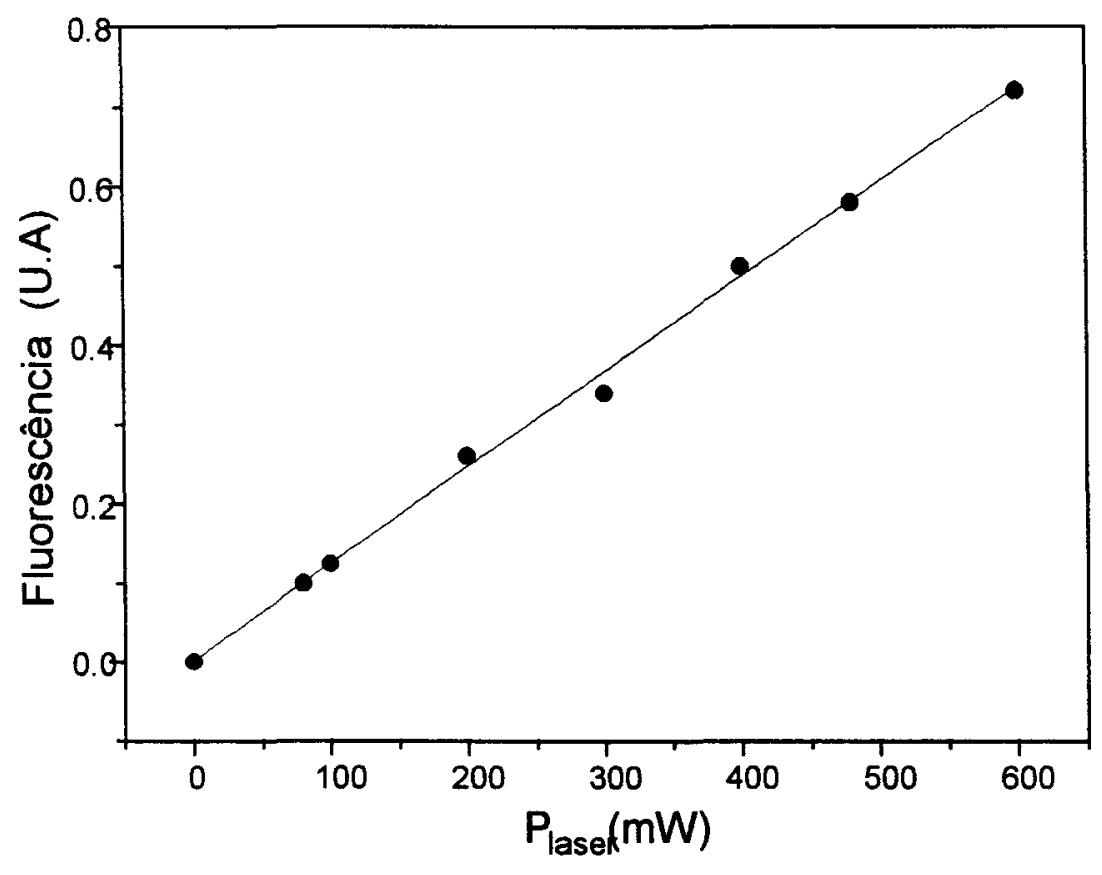

Figura 4.5-Variação da intensidade da fluorescência com a potência da luz laser de $\lambda=514 \mathrm{~nm}$ para 0 álcool furfurílico destilado. Foi usado uma cubeta de caminho ótico igual a $2.0 \mathrm{~mm}$.

Esse resultado de fluorescência poderia ser entendido pela presença de pequena quantidade impurezas no álcool, imperceptíveis às análises efetuadas. Para investigar a presença de impurezas foram feitas análises de cromatografia gasosa, cromatografia de coluna e espectroscopia de massa.

O resultado da cromatografia gasosa para o álcool furfurílico puro está na tabela 3. 
Tabela 3-Determinação da pureza do Álcool Furfurilico incolor com absorção máxima em 270nm, através de cromatografia Gasosa.

\begin{tabular}{|c|c|}
\hline Tempo de Retenção (min) & Concentração (\%) \\
\hline 2.75 (álcool furfurílico) & 99.56 \\
\hline 9.50 & 0.30 \\
\hline 11.59 & 0.14 \\
\hline
\end{tabular}

Assim podemos perceber que outros dois produtos além do AF estão presentes em concentração muito baixa no álcool furfurílico. Redestilando o álcool furfurílico e analisando por cromatografia gasosa esse produto escuro, resíduo da destilação, foram obtidos os seguintes compostos, cujos tempos de retenção estão na tabela (4).

Tabela 4-Compostos gerados a partir da resinificação térmica do AF através do processo de destilação à pressão reduzida e sua concentração relativa.

\begin{tabular}{|c|c|c|c|c|c|}
\hline T.R (min) & Conc (\%) & T.R (min) & Conc (\%) & T.R (min) & Conc (\%) \\
\hline 2.53 & 0.72 & 12.16 & 1.15 & 19.17 & 0.91 \\
\hline 2.75 & 12.78 & 13.05 & 22.04 & 19.73 & 2.56 \\
\hline 5.49 & 1.33 & 13.24 & 0.93 & 20.79 & 2.80 \\
\hline 5.83 & 11.66 & 15.16 & 1.02 & 25.97 & 1.20 \\
\hline 7.48 & 2.58 & 16.47 & 1.11 & 26.05 & 2.22 \\
\hline 11.59 & 32.98 & 17.98 & 2.00 & & \\
\hline
\end{tabular}

Nessa tabela podemos observar, uma contribuição alta de um composto com tempo de retenção $11.59 \mathrm{~min}$. Esse composto com tempo de retenção $11,59 \mathrm{~min}$ 
também está presente no líquido incolor e é possivelmente um dos causadores da fluorescência.

Para verificar essa hipótese, foi feita uma coluna cromatográfica com sílica, efetuando-se com ela a separação das frações. Essas frações foram recolhidas em função do tempo, resultando em duas: uma rica em compostos mais apolares, tabela 5 e a outra em compostos mais polares, tabela 6 . Essas frações retratam a afinidade desses compostos frente a coluna.

Tabela 5- Tempo de Retenção com concentração relativa na fração apolar, obtida por separação através de cromatografia de coluna.

\begin{tabular}{|c|c|c|c|c|c|}
\hline T.R (min) & Conc.(\%) & T.R (min) & Conc.(\%) & T.R (min). & Conc.(\%) \\
\hline 2.73 & 19.63 & 13.05 & 2.37 & 22.40 & 7.25 \\
\hline 5.82 & 28.99 & 15.15 & 3.00 & 22.55 & 18.79 \\
\hline 7.47 & 3.64 & 21.31 & 3.15 & 29.46 & 4.58 \\
\hline 11.59 & 4.63 & 21.64 & 3.99 & & \\
\hline
\end{tabular}

Tabela 6-Tempo de Retenção com concentração relativa na fração polar, obtida por separação através de cromatografia de coluna.

\begin{tabular}{|c|c|c|c|c|c|}
\hline T.R (min) & Conc.(\%) & T.R (min) & Conc.(\%) & T.R (min) & Conc.(\%) \\
\hline 2.72 & 2.69 & 13.05 & 50.80 & 18.96 & 0.67 \\
\hline 5.89 & 9.60 & 15.15 & 0.59 & 20.77 & 5.50 \\
\hline 7.46 & 1.47 & 16.46 & 0.78 & 25.96 & 4.83 \\
\hline 11.59 & 10.16 & 18.72 & 0.44 & 26.04 & 8.38 \\
\hline 12.14 & 3.33 & 18.84 & 0.71 & & \\
\hline
\end{tabular}


Coletando as frações onde havia maior concentração do composto de tempo de retenção 11.59minutos, e excluindo as outras frações, obtive a seguinte composição relativa, tabela (7).

Tabela 7-Distribuição de compostos na fração separada através de cromatografia de coluna e enriquecida em compostos com o tempo de retenção de $11.59 \mathrm{mim}$ e $13.05 \mathrm{~min}$.

\begin{tabular}{|c|c|}
\hline T.R (min) & Conc (\%) \\
\hline 5.83 & 10.49 \\
\hline 11.59 & 40.52 \\
\hline 13.05 & 45.72 \\
\hline 23.17 & 3.27 \\
\hline
\end{tabular}

O produto com tempo de retenção $11.59 \mathrm{~min}$, agora em maior concentração foi analisado por cromatografia gasosa acoplada a espectrômetro de massa [25,26], e o seguinte espectro de fragmentação foi obtido, figura 4.6.

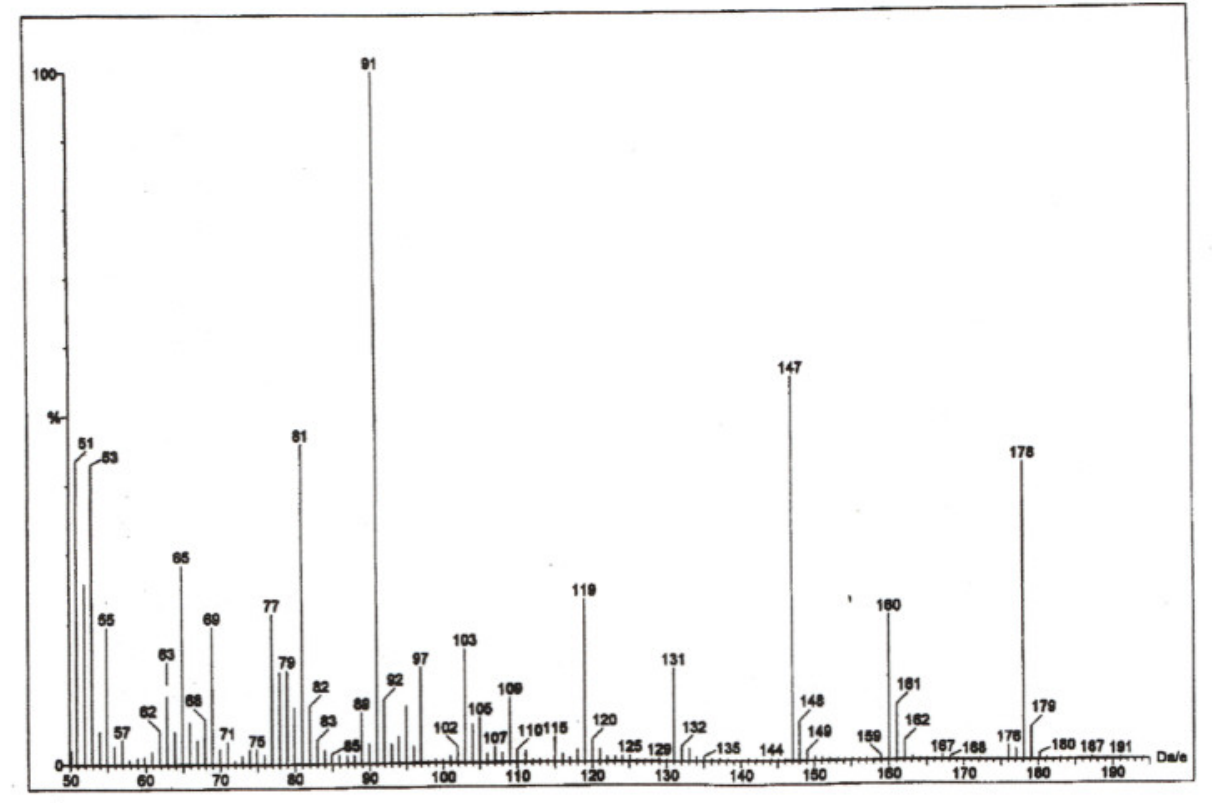

Figura 4.6-Espectro de Massa do composto obtido por separação através de cromatografia gasosa e analisado por espectroscopia de massa, cujo tempo de retenção, TR, era de $11.59 \mathrm{~min}$. 
A análise do espectro de massa mostra um pico que corresponde a um composto de massa $178 \mathrm{~g} / \mathrm{mol}$, que coincide com o do dímero AF. Analisando os outro picos, verificamos a perda de uma molécula de água em $160 \mathrm{~g} / \mathrm{mol}$, a perda do grupo metila em $147 \mathrm{~g} / \mathrm{mol}$, a presença do íon aromático em $91 \mathrm{~g} / \mathrm{mol}$ e presença de um radical furóico em $81 \mathrm{~g} / \mathrm{mol}$, também referentes ao composto de $178 \mathrm{~g} / \mathrm{mol}$. Esses resultados conduzem a seguinte estrutura:<smiles>OCc1ccc(Cc2ccco2)o1</smiles>

Figura 4.7-Representação da estrutura do composto obtido através da fragmentação do espectro de massa relativa ao tempo de retenção de $11.59 \mathrm{mim}$. Este composto é o dímero do álcool furfurílico de estrutura não conjugada.

Com isso podemos perceber que existe a formação de moléculas pequenas (dímeros não conjugados), de estrutura semelhante ao AF que estão presentes no álcool furfurílico. Em razão da sua baixa concentração não pode ser percebido pelas técnicas de RMN e IR. Essas moléculas são geradas através de uma reação onde há eliminação de água. Atribuímos a fluorescência observada a pequena concentração de dímeros do $\mathrm{AF}$, que se formam naturalmente.

Como temos inicialmente três compostos no AF incolor, podemos concluir que o terceiro composto deve ser água. Já é conhecido que a água não apresenta absorção no visível e também não pode ser a responsável pelo processo de absorção, tampouco pela fluorescência. No entanto, a presença do dímero mesmo em concentração muito baixa, poderia suscitar dúvidas a respeito do espectro de 
absorção ótica no AF. Com o intuito de confirmar os resultados, foi medido o coeficiente de extinção do álcool em solução de DCM, figura 4.8.

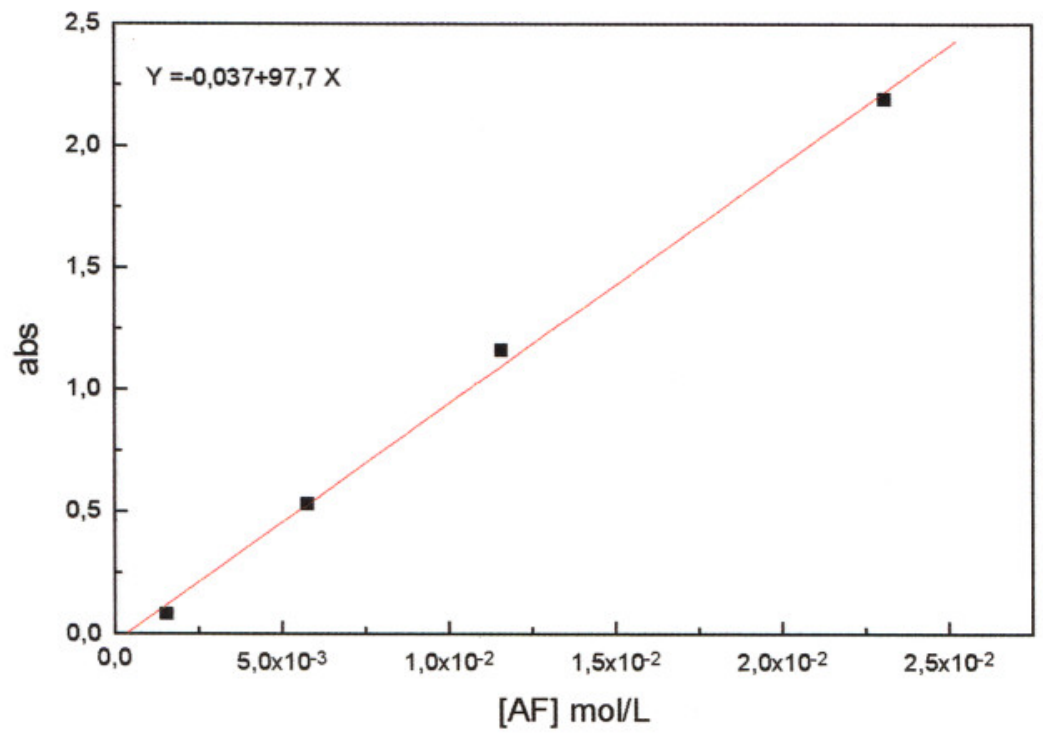

Figura 4.8-Determinação do Coeficiente de Extinção do AF. O gráfico apresenta uma variação da concentração do álcool em DCM com a intensidade do sinal na absorção máxima; $\lambda=270 \mathrm{~nm}$.

O logaritmo do coeficiente de extinção da banda em $270 \mathrm{~nm}$ foi de 1.98 . Este valor está de acordo com o valor da literatura $(\log \varepsilon=2.0)$ [4], contudo podemos perceber que há um pequeno desvio de $3.7 \%$ no ajuste linear dos pontos.

As análises realizadas nos permitem concluir que o álcool furfurílico empregado em nossos experimentos contém pequena quantidade de dímeros e água, em quantidades imperceptíveis no espectro de absorção ótica no ultravioleta e no visível. Esses produtos não foram eliminados totalmente durante o processo de purificação do álcool. 


\section{2-PROPRIEDADES MECÂNICAS}

Imediatamente após a exposição do tubo capilar em "U" contendo o $\mathrm{AF}$, figura 4.9, ao vapor do ácido clorídrico ocorre à formação de uma película na interface álcool furfurílico/vapor de ácido que se desloca na forma de uma frente azul contínua, atingindo o fundo do tubo capilar, figuras 4.10 e 4.11 , mantendo uma ligeira e constante curvatura durante a queda.

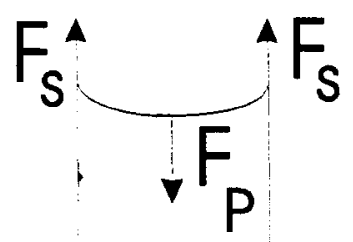

Figura 4.9-Representação esquemática da frente que se desloca no capilar de vidro borosilicato. Fs é uma força de sustentação que surge em função do perímetro e $F_{P}$ é a força peso que é maior no centro da película.

Para capilares de raio inferiores a $2,7 \mathrm{~mm}$ a velocidade de queda depende linearmente do quadrado do raio do capilar. Portanto, nessas condições a relação $\mathrm{V} / \mathrm{R}^{2}$ mantém-se constante para todos os capilares, figura 4.12. Para capilares de diâmetros superiores a curvatura da frente se acentua bastante tornando a sua interface com o AF instável como será mostrado mais adiante. 
Nos tubos capilares com dois ramos, um inteiramente vertical figura $3.2 \mathrm{e}$ outro contendo uma parte na horizontal, como mostra a figura 3.3, o deslocamento da frente de cor azul foi diferente. No ramo A a velocidade é normal, figura 3.3, isto é, igual a dos tubos com os dois ramos na vertical. Ao atingir o fundo do tubo à frente estaciona, o que demonstra ser o seu peso o agente do movimento de caída, descartando assim o movimento difusional. No ramo B, figura 3.3, a frente percorre o trecho horizontal com velocidade variável, figura 4.17.

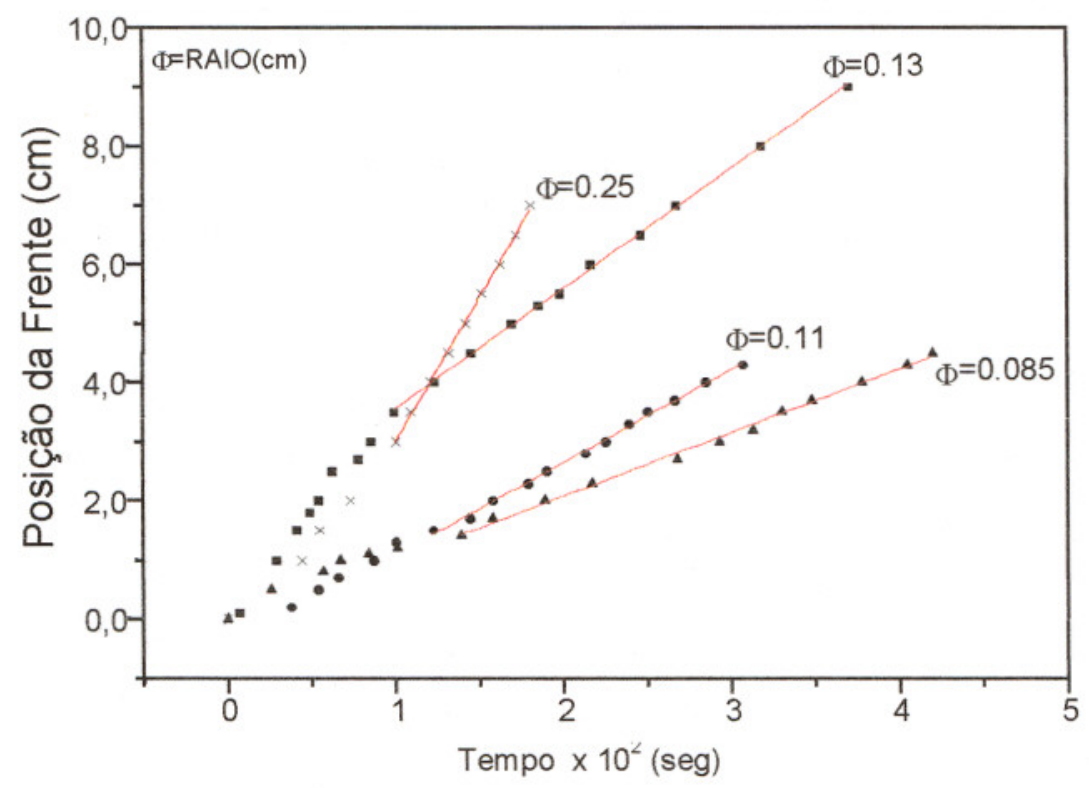

Figura 4.10-Determinação da velocidade limite de deslocamento da frente para capilares em "U" de borosilicato, com raio até $0.25 \mathrm{~cm}$. 


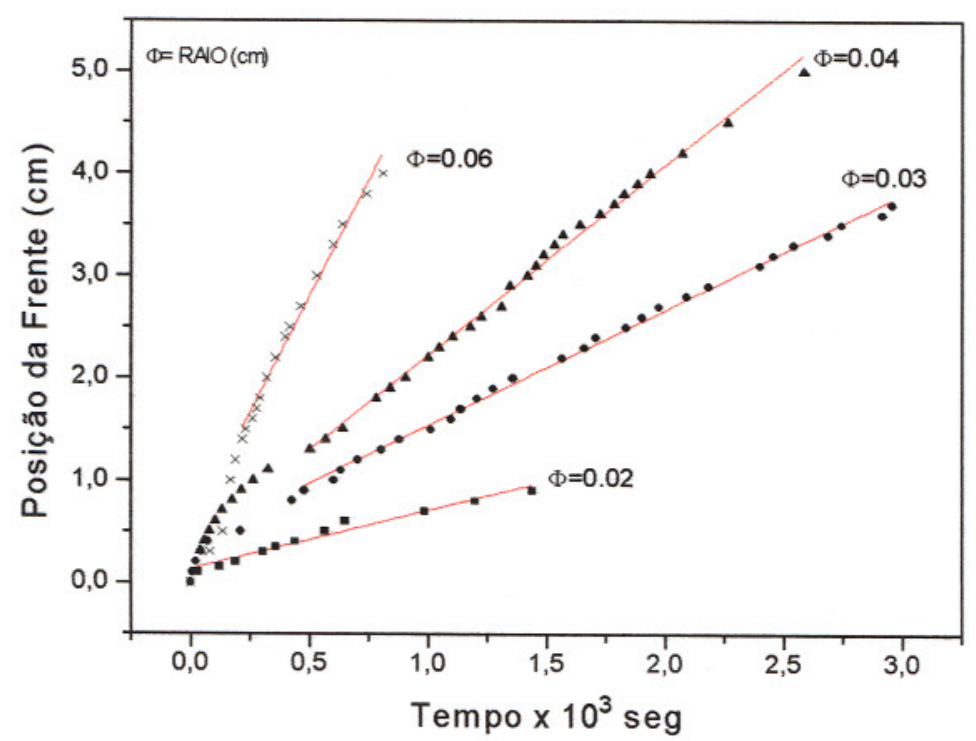

Figura 4.11-Determinação da velocidade limite de deslocamento da frente para capilares em "U" de borosilicato, com raio até $0.6 \mathrm{~mm}$.

Tabela 8-Velocidade limite para queda da frente azul nos capilares de borosilicato como na figura 4.10 e 4.11 .

\begin{tabular}{|c|c|}
\hline Raio $(\mathrm{cm})$ & Velocidade Limite $\times 10^{-4}(\mathrm{~cm} / \mathrm{seg})$ \\
\hline 0.02 & 5.0 \\
\hline 0.03 & 12.0 \\
\hline 0.04 & 19.0 \\
\hline 0.06 & 47.0 \\
\hline 0.09 & 100.0 \\
\hline 0.11 & 151.0 \\
\hline 0.13 & 249.0 \\
\hline 0.25 & 434.0 \\
\hline
\end{tabular}




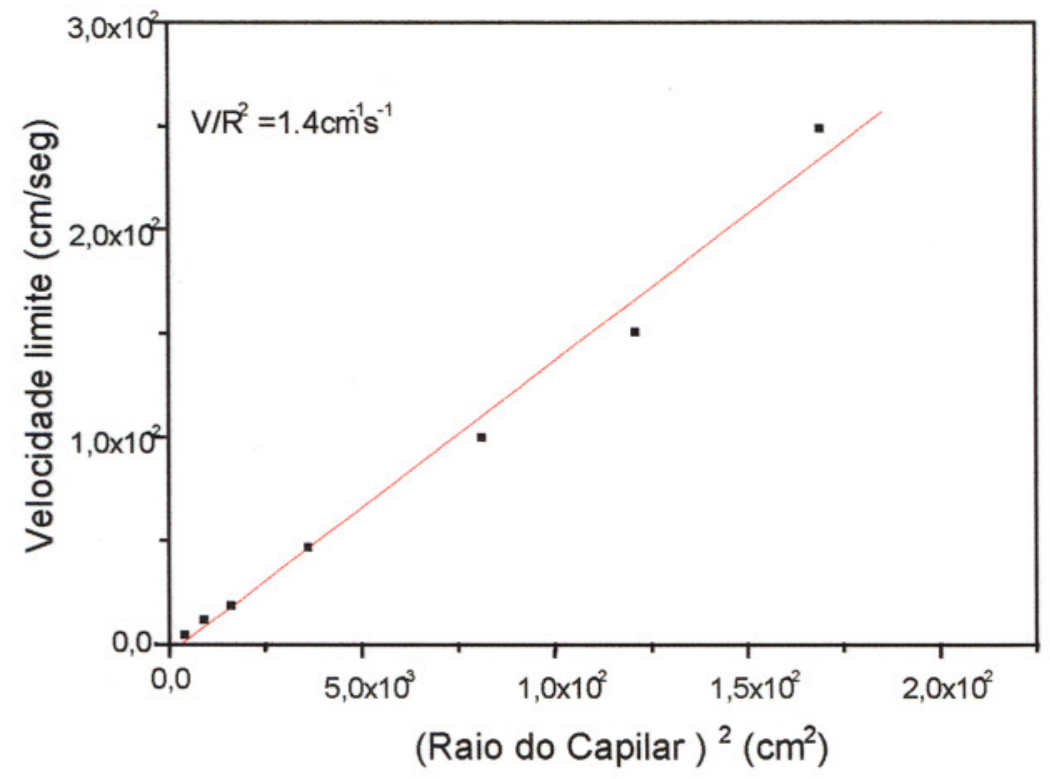

Figura 4.12-Determinação da relação de $\mathrm{V} / \mathrm{R}^{2}$ para capilares de borosilicato. Essa relação tem um bom coeficiente de correlação linear e assume o valor constante de $1.4 \mathrm{~cm}^{-1} \mathrm{~s}^{-1}$.

Nos experimentos com soluções de diclorometano em AF, cujas densidades são maiores do que a do $\mathrm{AF}$ puro, as velocidades de queda da frente de cor azul são menores tornando-se muito baixa quando a concentração de DCM atinge $48 \%$ em volume, figura 4.13 e tabela (9). Podemos perceber que quando a solução é de $20 \%$, temos dois processos distintos. O primeiro, manifesta-se quando a película é formada e cai com velocidade constante e mantendo uma frente contínua durante o processo e o segundo quando essa frente sente a ação da solução do álcool em DCM e se dissolve, destruindo o perfil de queda da frente e começa a cair irregularmente e com uma velocidade maior.

Quando a concentração é de $48 \%$ a formação da película na interface álcoolvapor de ácido dentro do capilar é muito demorada em função da concentração de monômeros na superfície, além disso, a densidade do líquido em que à frente está caindo é maior e diminui a velocidade de queda da película. 
Tabela 9-Comparação entre o valor da velocidade limite e a densidade da Solução. A densidade da solução foi obtida através de uma combinação linear da concentração da solução.

\begin{tabular}{|c|c|c|}
\hline $\begin{array}{c}\text { Concentração (\%) } \\
\text { de DCM }\end{array}$ & Densidade $(\mathrm{g} / \mathrm{ml})$ & Velocidade limite $\times 10^{-4}(\mathrm{~cm} / \mathrm{seg})$ \\
\hline 0 & 1.135 & 100 \\
\hline 20 & 1.173 & 27 \\
\hline 48 & 1.227 & 6 \\
\hline
\end{tabular}

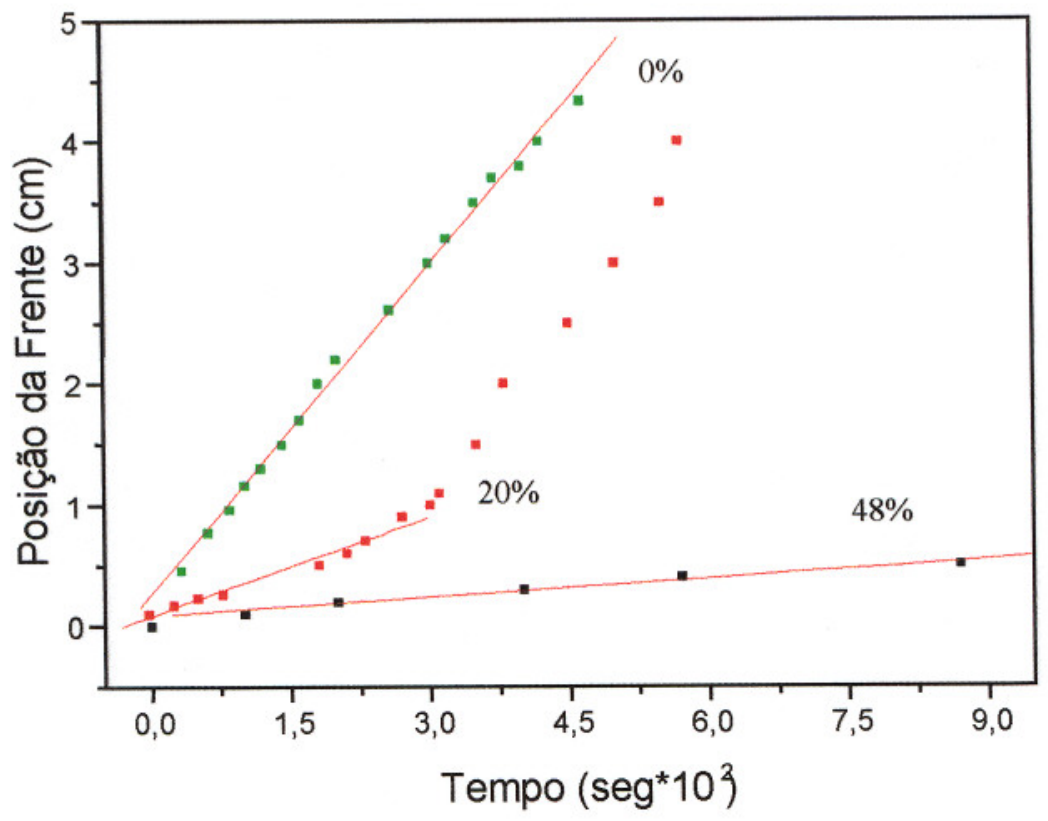

Figura 4.13-Determinação da velocidade limite de deslocamento da frente azul a partir da superfície para o fundo dos capilares em "U" em função da densidade da solução AF/DCM. 


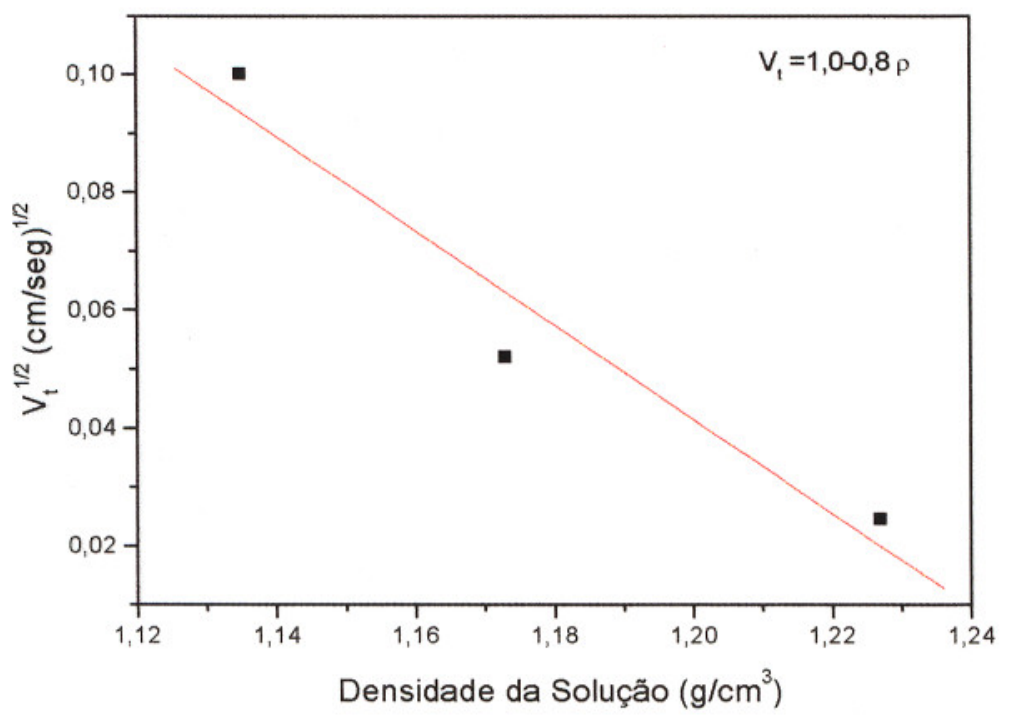

Figura 4.14-Dependência da velocidade limite na queda da frente azul em função da densidade da solução AF/DCM.

A cor azul observada é devida à absorção óptica dos oligômeros formados durante o processo de polimerização na interface álcool furfurílico/vapor de $\mathrm{HCl}$. No processo de queda da frente de cor azul essa interface é permanentemente renovada, isto é, álcool furfurílico emerge na superfície através da película que cai. Portanto essa película tem que ser porosa. Quando a frente atinge a parte mais baixa do capilar o tubo é retirado do ambiente contendo os vapores de $\mathrm{HCl}$. Após algumas horas dessa retirada do tubo encontra-se no seu interior polímero de cor escura, indicando que a reação de polimerização continuou levando a formação de polímeros de maior peso molecular, aproximando-se da formação da resina termofixa. Portanto, no seu processo de queda, a película de oligômeros traz para o interior do tubo as moléculas de $\mathrm{HCl}$ responsáveis pela sua formação na interface com'o vapor de ácido. Essa formação dos oligômeros na interface com o vapor de ácido voltará a ser abordada quando tratarmos de suas propriedades ópticas. 
Sendo os oligômeros polímeros com poucos meros, neste caso inferior a dez, se esperaria que tais moléculas permanecessem em solução, não havendo razão aparente para que caíssem da forma organizada como ocorre. Normalmente, oligômeros desse tamanho permanecem em solução devido à agitação molecular. Quando o tamanho de uma partícula, ou agregado de partículas, no interior de um líquido atinge valores próximos a $1,0 \mu \mathrm{m}$ os efeitos dos choques moleculares se anulam permitindo que o campo gravitacional prevaleça e o corpo caia. Afím de confirmar a existência de agregados de oligômeros duas experiências foram feitas. $\mathrm{Na}$ primeira um tubo onde estava ocorrendo à queda da frente azul foi agitado fortemente o que fez com que a queda cessasse. Na outra, vapores de uma solução de $\mathrm{HCl}$ foram borbulhados por meio de uma corrente de $\mathrm{N}_{2}$ gasoso, no seio de $\mathrm{AF}$ contido num becker, desenvolvendo-se a mesma cor azulada. Esse material foi centrifugado sem apresentar qualquer evidência de separação de fases. Estes experimentos confirmam que a queda que se observa no tubo é de um agregado de oligômeros.

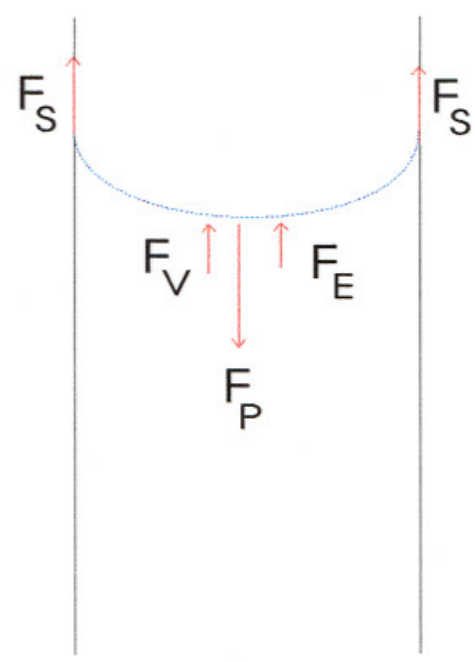

Figura 4.15-Representação esquemática das forças que agem sobre a película que se forma sobre a superfície do capilar. 
Tais agregados devem constituir uma película que se estende até a parede interna do capilar para que possa se efetivar a dependência da velocidade de queda com o raio do capilar. A figura acima ilustra as forças que estão envolvidas na movimentação da película: o seu peso próprio, $F_{P}$, o empuxo, $F_{E}$, a força viscosa devido à passagem do álcool pelos poros da película, $\mathrm{F}_{\mathrm{v}}$, e uma força viscosa ao longo do perímetro da película, $\mathrm{F}_{\mathrm{s}}$, devido à presença da parede do tubo de vidro. As três primeiras forças se exercem uniformemente em toda a superfície da película. A última força exerce um papel relevante na queda da película, sua presença estando garantida pelas seguintes observações experimentais. Quando o raio do capilar é superior a $2.7 \mathrm{~mm}$ a película começa a se romper vagarosamente na sua parte central durante a queda. Para raios maiores observa-se a formação de gotas escuras na forma aproximada de pêras que caem rapidamente. A figura 4.16 é uma ilustração do processo de formação dessas gotas.

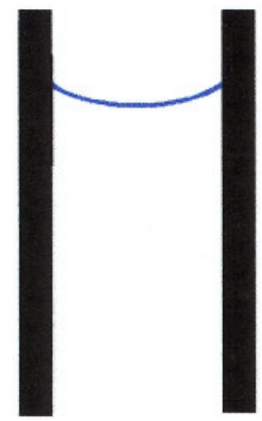

1

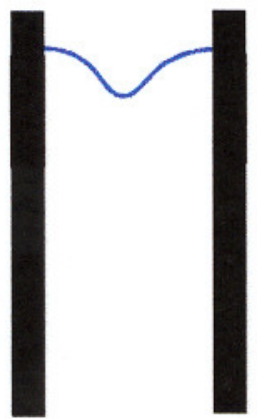

2

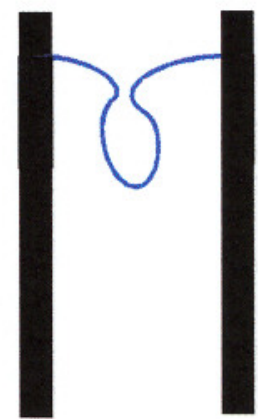

3

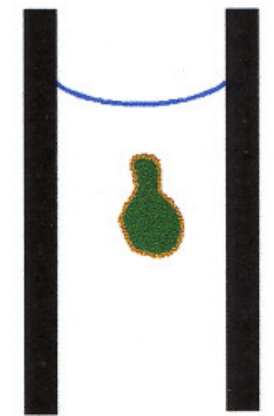

4

Figura 4.16-Representação do mecanismo de formação da película e seu rompimento a partir da superfície dos tubos capilares raio superior a $2.7 \mathrm{~mm}$. O rompimento dessa película desenvolve a formação gotas escuras dentro do capilar, que caem segundo o esquema.

Podemos evidenciar a formação das vesículas em estágios distintos. No primeiro é criado na interface álcool/ácido uma película que se estende por toda a 
área da superficie do capilar e está presa a parede do capilar. No segundo estágio, começa a haver uma deformação dessa película, ocasionada pela ação do seu peso. No terceiro estágio essa força imposta pelo peso a película atinge um valor limite para sua sustentação. No quarto estágio há um rompimento dessa película formada na interface pela resultante da ação do seu peso e da força de sustentação. Esse processo ocasiona o aumento local da concentração de ácido dentro da vesícula, pois ao romper-se, arrasta consigo o vapor ácido contido na interfase. Nota-se também que após o rompimento outros fragmentos continuam a cair, agora com velocidade maior do que a da película, não se dissolvendo no álcool, portanto trata-se da caída de pedaços de agregados.

Vamos considerar agora o, equilíbrio das forças acima mencionadas. Em primeira aproximação vamos desprezar a força viscosa, através da película, $F_{v}$. A razão dessa aproximação pode ser entendida através do seguinte argumento. Se essa força fosse maior do que a força exercida para cima pelo contato da película com a parede então a película não se romperia como foi observado. Podemos escrever então:

$$
\begin{aligned}
& \left(F_{P}-F_{E}\right)=F_{S} \\
& F_{S}=\pi r^{2} \delta g \Delta \rho
\end{aligned}
$$

Aonde $\mathbf{r}$ é o raio do capilar, $\delta$ a espessura da película, $\mathbf{g}$ a aceleração da gravidade e $\Delta \rho$ a diferença de densidade entre o oligômero e o álcool furfurílico.

A força $F_{S}$ deve depender da velocidade para que seja atingida uma velocidade limite, assim vamos escrever uma expressão genérica e determinar as constantes por ajuste com os valores encontrados experimentalmente. Essa força 
deve depender do perímetro do capilar, da espessura da película e de sua velocidade relativa a parede do tubo, aonde $\beta$ e n são constantes.

$$
\mathrm{F}_{\mathrm{s}}=2 \pi \mathrm{r} \delta \beta \mathrm{v}^{\mathrm{n}}
$$

Igualando-se (1) e (3) obtém-se:

$$
\mathrm{V}^{\mathrm{n}}=\left(\frac{\mathrm{g} \Delta \rho}{2 \beta}\right) \mathbf{r}
$$

Igualando-se com o resultado experimental, $\mathrm{V} / \mathrm{R}^{2}=\mathbf{C}$, chegamos a conclusão que $n=1 / 2$ ou:

$$
\mathrm{V}=\left(\frac{\mathrm{g} \Delta \rho}{2 \beta}\right)^{2} \mathrm{r}^{2}
$$

Para isto caso, o valor de $C$ é $1.4 \mathrm{~cm}^{-1} \mathrm{~s}^{-1}$.

A figura 4.14 mostra a relação entre $\mathrm{v}$ e $\Delta \rho$, obtida experimentalmente, fazendo-se a polimerização em solução de AF em DCM. Como a densidade do DCM $(1,273)$ é maior do que a do AF $(1,135)$ o empuxo aumenta, diminuindo a velocidade para valores crescentes da concentração de DCM. A dependência observada está de acordo com a equação (5), confirmando que a força viscosa através da película é muito pequena, o que pode ser entendido como sendo devido a sua elevada porosidade. 
O movimento da frente azul ao longo da seção horizontal do capilar, pode ser entendido considerando-se as mesmas forças que resultaram na equação (5), figura 4.15. A força que impulsiona o movimento dos oligômeros é o seu peso no ramo vertical $\mathbf{B}$, figura 3.3, que impulsionará todo o restante contra a força de atrito com a parede interna do capilar.

$$
\begin{aligned}
& F_{p}=\pi r^{2} \Delta \rho g h \\
& F_{s}=2 \pi r \beta(L+h) v^{\frac{1}{2}}
\end{aligned}
$$

Admitindo o equilíbrio entre essas forças temos:

$$
\begin{aligned}
& F_{s}=F_{p} \\
& 2 \pi r \beta(L+h) v^{\frac{1}{2}}=\pi r^{2} \Delta \rho g h
\end{aligned}
$$

Ou o mesmo que:

$$
\mathrm{v}=\left(\frac{\mathrm{r} \Delta \rho \mathrm{g}}{2 \beta}\right)^{2} \frac{\mathrm{h}^{2}}{(\mathrm{~L}+\mathrm{h})^{2}}
$$

Para $L=0$, isto é, para velocidade em que a frente irá entrar no ramo horizontal temos: 


$$
\mathrm{v}_{\mathrm{o}}=\left(\frac{\mathrm{r} \Delta \rho \mathrm{g}}{2 \beta}\right)^{2}
$$

Portanto temos:

$$
v=v_{0}\left(\frac{h}{L+h}\right)^{2}
$$

Sabendo que:

$$
\mathrm{v}=\frac{\mathrm{dL}}{\mathrm{dt}}
$$

Podemos igualar (12) e (13), chegando a:

$$
\frac{\mathrm{dL}}{\mathrm{dt}}=\mathrm{v}_{0}\left(\frac{\mathrm{h}}{\mathrm{L}+\mathrm{h}}\right)^{2}
$$

Integrando, temos:

$$
\int_{0}^{t} v_{0} d t=\int_{0}^{L}\left(\frac{L+h}{h}\right)^{2} d L
$$

Que após a substituição passamos a ter: 


$$
v_{0} t=\frac{(L+h)^{3}}{3 h^{2}}-\frac{h^{3}}{3 h^{2}}
$$

Que pode ser expressa da seguinte forma:

$$
3 v_{0} h^{2} t=(L+h)^{3}-h^{3}
$$

No nosso experimento $\mathrm{h}=1,0 \mathrm{~cm}$. As tabelas (10) e (11) mostram respectivamente os dados experimentais, obtidos com a aparelhagem da figura 3.3. A figura 4.17 mostra o ajuste obtido.

Tabela 10-Dependência do tempo de deslocamento da frente em um ramo horizontal de um capilar de $0.11 \mathrm{~cm}$ de raio.

\begin{tabular}{|c|c|c|c|c|c|}
\hline $\mathrm{t}(\mathrm{Seg})$ & 0 & 800 & 3400 & 6400 & 9400 \\
\hline $\mathrm{L}(\mathrm{cm})$ & 0 & 0.5 & 1.0 & 1.5 & 1.75 \\
\hline
\end{tabular}

Tabela 11-Anamorfismo dos dados experimentais segundo a equação [17].

\begin{tabular}{|c|c|c|c|c|c|}
\hline $\begin{array}{c}(\mathrm{L}+\mathrm{h})^{3}-\mathrm{h}^{3}, \text { para } \\
\mathrm{h}=1,0 \mathrm{~cm}\end{array}$ & 0 & 2,4 & 7,0 & 14,6 & 19,8 \\
\hline $\mathrm{t}(\mathrm{seg})$ & 0 & 800 & 3400 & 6400 & 9400 \\
\hline
\end{tabular}




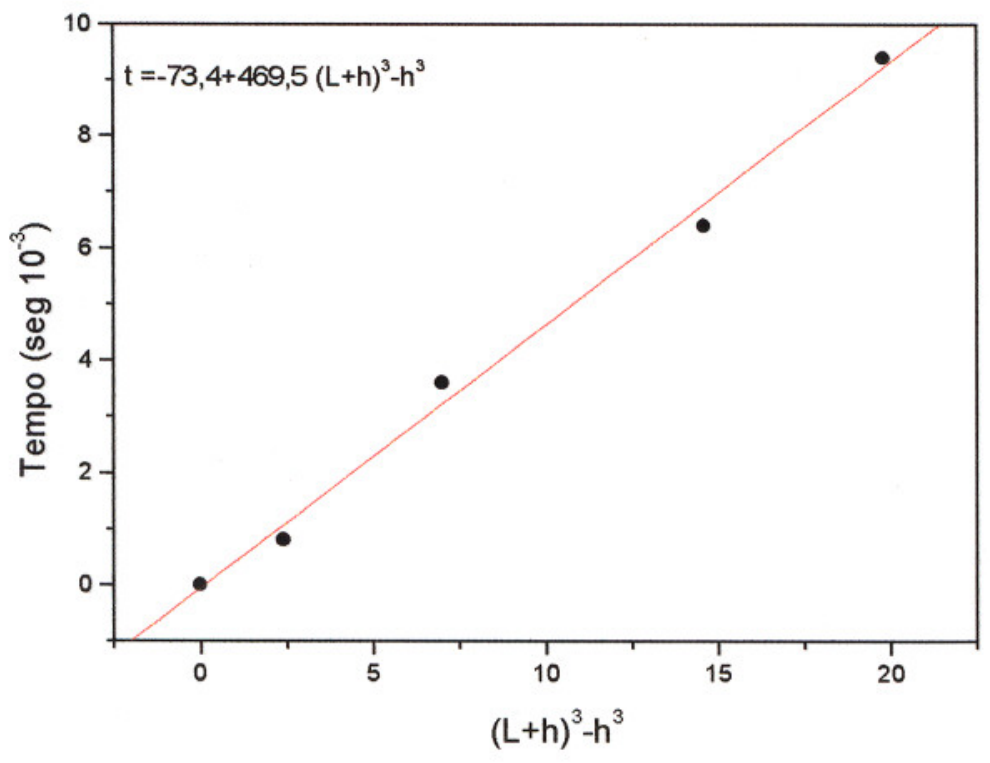

Figura 4.17-Correlação entre o tempo e a distância de percurso da frente nos capilares com o braço horizontal, segundo a equação (17).

Podemos concluir destes resultados que o movimento de queda da película é devido as seguintes forças: seu peso próprio menos o empuxo e uma força ao redor do seu perímetro dependente da raiz quadrada da velocidade . A ligeira curvatura da película no seu movimento é devido a essas forças. Essa película porosa é formada por oligômeros que se auto-organizam na superfície do álcool furfurílico exposta ao $\mathrm{HCl}$.

Observando-se que a curvatura da película próxima a parede do tubo é aproximadamente $15^{\circ}$, torna-se necessária a presença de uma força atrativa entre ·a película e o vidro $\left(\mathrm{F}_{\mathrm{A}}\right)$ e uma outra, de natureza viscosa entre a película e o capilar. A resultante entre essas duas forças gera uma força $\mathbf{T}$, que é responsável pelo tracionamento da película no capilar, tal que a resultante $\mathbf{T}$ seja ao longo do ângulo de inclinação da película. 


\section{3-ABSORÇÃo ÓPTICA UV-VISÍVEL}

Vamos analisar agora os espectros de absorção óptica dos oligômeros que resultam da catálise do álcool furfurílico pelo ácido clorídrico em diferentes situações, no interior de capilares com raios distintos, $1.1 \mathrm{~mm}$ e $0.85 \mathrm{~mm}$, e por borbulhamento do vapor de solução de ácido clorídrico $6 \mathrm{~N}$, conduzido por gás nitrogênio, em álcool furfurilico contido em um becker. Os detalhes de como tais medidas foram realizadas já foram anteriormente descritos. Apresenta-se também o estudo do espectro de absorção óptica do álcool furfurilico envelhecido apresentando cor amarela e o espectro da solução de oligômeros neutralizada com trietilamina obtida a partir do tubo capilar de raio $0.85 \mathrm{~mm}$.

Em cada caso apresenta-se o espectro acompanhado da sua decomposição em Gaussianas, em função da melhor correlação com os resultados experimentais. Para facilitar o entendimento apresentam-se também os parâmetros de construção das Gaussianas e suas propriedades após a normalização. Na tomada desses espectros a absorção devido ao AF puro foi eliminada colocando-se na cubeta de referência uma solução de AF em DCM. Para comprimentos de onda abaixo de 320nm a absorção da referência pode causar abertura da fenda do monocromador, provocando a perda da resolução durante a medida. 


\subsection{1-A DECOMPOSIÇÃO EM GAUSSIANAS}

O modelo empregando decomposição em Gaussianas de espectros de UVVisível já é bem conhecido. Nesse modelo, podemos reconstruir uma espectro de absorção pela soma de Gaussianas. A expressão usada para decompor os espectros de absorção foi a seguinte:

$$
\mathrm{abs}=\mathrm{abs}_{0}+\frac{\mathrm{A}}{\mathrm{w} \sqrt{\pi / 2}} \mathrm{e}^{\frac{-2\left(\lambda-\lambda_{\max }\right)^{2}}{\mathrm{w}^{2}}}
$$

Aonde abs é a absorção ótica, A uma constante que está relacionada com o máximo da absorção e abs ${ }_{0}$ é o fundo de escala, $\lambda$ e $\lambda_{\max }$ representam o comprimento de onda em cada ponto da curva e no máximo de absorção, respectivamente. $\mathrm{O}$ valor de W possui a mesma dimensão de $\lambda$, ou seja, é expresso em nanômetro (nm). Seu valor está relacionado com o comprimento da largura de meia-banda de absorção.

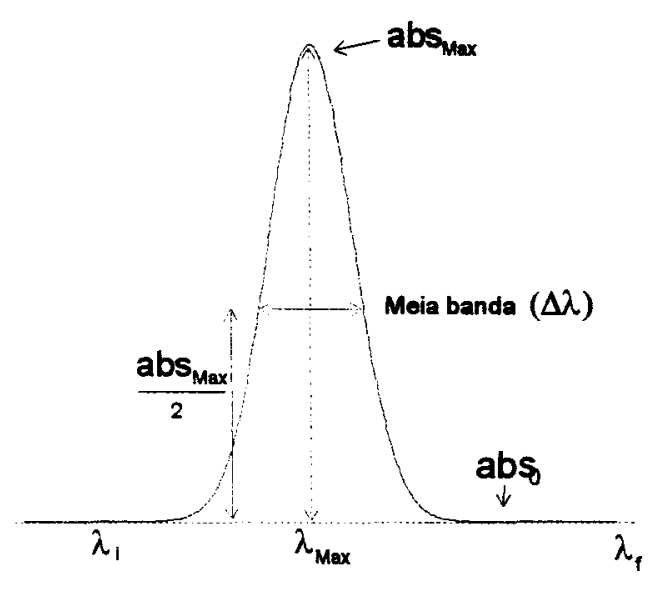

Figura 4.18-Representação gráfica dos termos da equação Gaussiana sob a curva. 
O espectro de absorção óptica foi decomposto segundo o modelo de Gaussianas, equação (18). Através dessa equação foi possível obter os parâmetros relativos a cada curva, usando para isso, a aproximação não-linear do software ORIGIN 4.1 e o programa FORTRAN 77 para reconstruir as curvas segundo os parâmetros obtidos do software ORIGIN 4.1.

\subsection{2-POLIMERIZAÇÃO EM CAPILARES DE VIDRO}

Os capilares de vidro com diferentes raios foram expostos ao vapor do ácido. Através dos experimentos de determinação da velocidade, sabemos que o raio influência na velocidade de queda ao longo do capilar. Isto é explorado com o intuito de interferir nos produtos da reação de polimerização.

\subsubsection{1-SOLUÇÃO DE OLIGÔMEROS USANDO CAPILAR DE RAIO $0.85 \mathrm{~mm}$}

A superficie do capilar de raio $0.85 \mathrm{~mm}$ foi exposta a uma câmara contendo ácido clorídrico concentrado $(\mathrm{N}=12 \mathrm{~N})$, durante $5 \mathrm{~min}$. Durante esse tempo foi gerada uma película na interface álcool-ácido, que caiu na forma de uma frente azul dentro do capilar, sendo armazenada no pequeno balão adaptado, figura 3.4. A retirada do balão promove uma agitação, transformando esse aglomerado de películas em uma solução de cor azul, da qual seu espectro de absorção ótica foi medido, figura (4.19). Durante o processo de recolhimento a organização da película desapareceu por ter gerado uma solução que manteve sua coloração estável. O espectro ótico tratado através da decomposição em Gaussianas fornece os parâmetros que estão na tabela 12 . 
espectro ótico tratado através da decomposição em Gaussianas fornece os parâmetros que estão na tabela 12 .

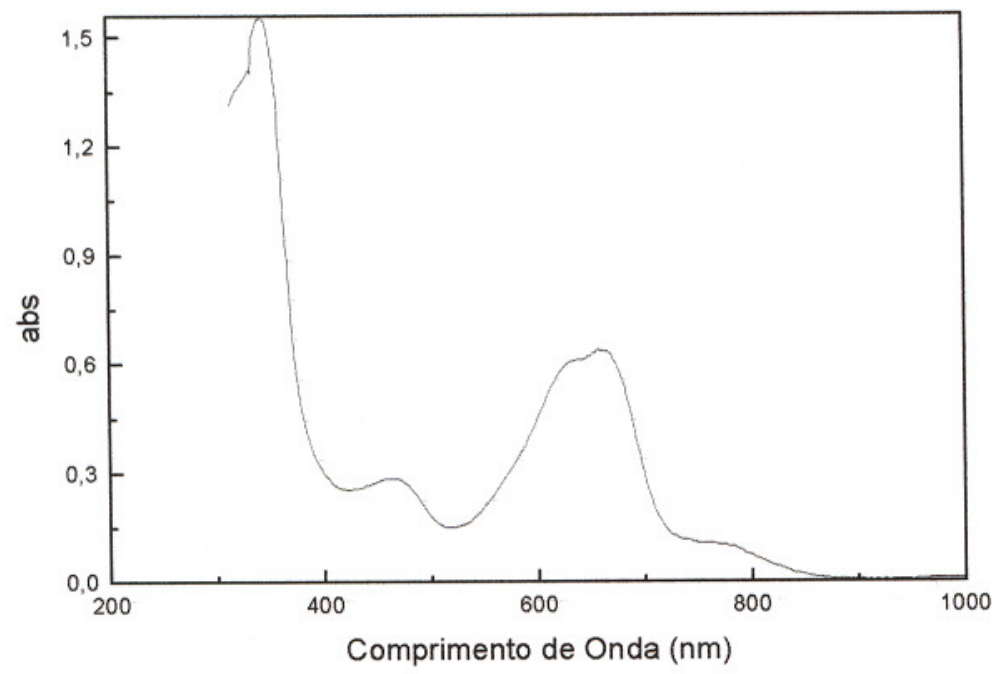

Figura 4.19-Espectro de absorção ótica UV-Visível da solução de cor azul, obtida através da catálise do álcool furfurílico exposto na superfície de capilares de borosilicato com raio de $0.85 \mathrm{~mm}$. Catálise realizada com o vapor do ácido clorídrico $(\mathrm{N}=12 \mathrm{~N})$. Foi usado para referência solução de álcool furfurílico e DCM e uma cubeta de caminho óptico de $10.0 \mathrm{~mm}$.

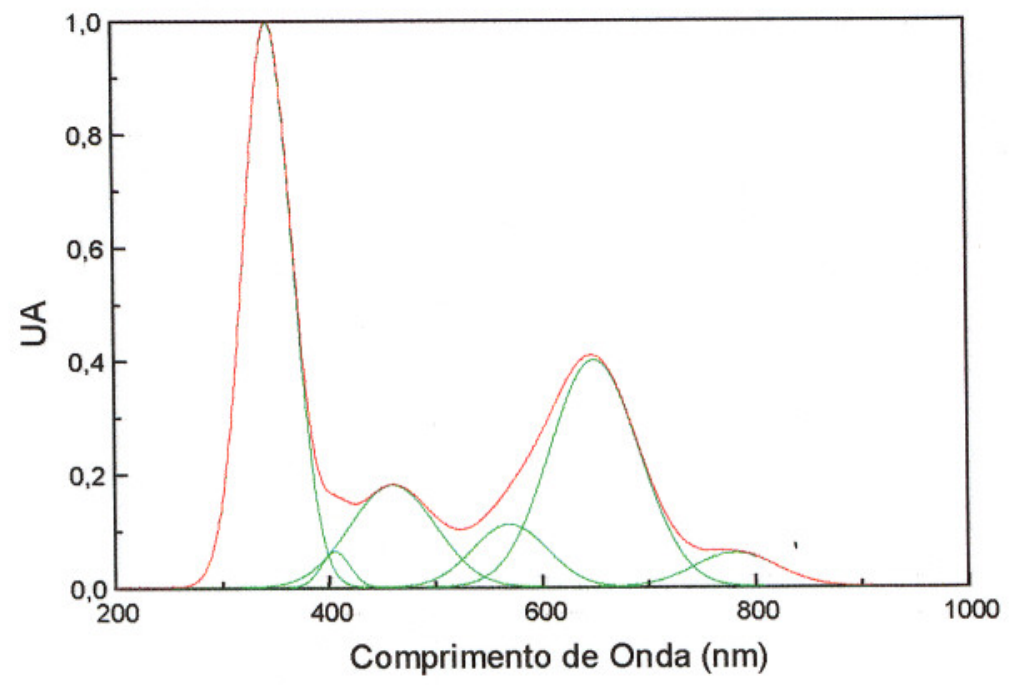

Figura 4.20-Decomposição em Gaussianas do espectro ótico da solução azul obtida através exposição da interface álcool-ácido contido em um capilar de $0.85 \mathrm{~mm}$ de raio. Em verde está cada uma das curvas individualmente e em vermelho a sua soma. 


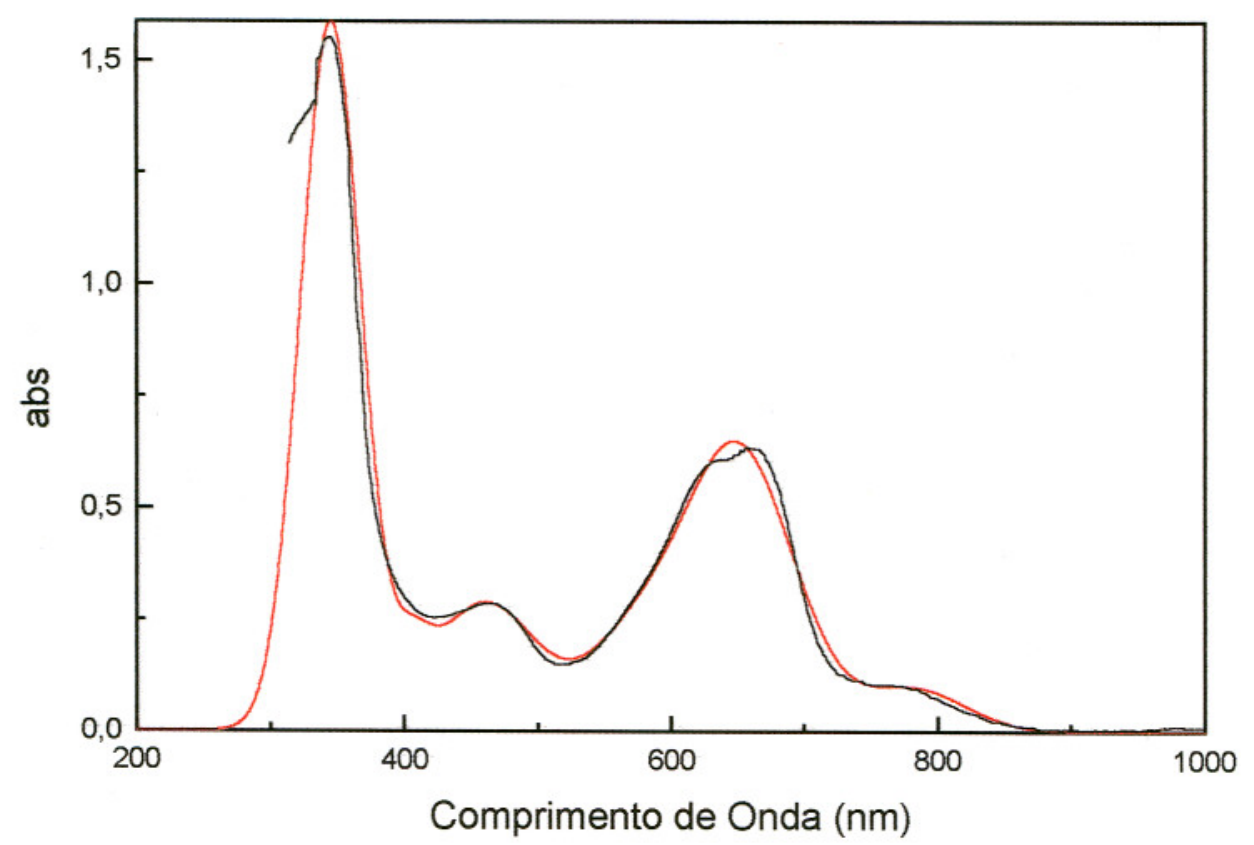

Figura 4.21- Espectro de absorção ótica UV-Visível da solução de cor azul, obtida através da catálise do álcool furfurílico exposto na superfície de capilares de borosilicato com raio de $1.1 \mathrm{~mm}$. Catálise realizada com o vapor do ácido clorídrico $(\mathrm{N}=12 \mathrm{~N})$. Foi usado para referência solução de álcool furfurílico e DCM e uma cubeta de caminho óptico de $10.0 \mathrm{~mm}$.

Tabela 12-Aonde: $\mathrm{abs}_{0}=$ linha de base; $\lambda_{\max }=$ comprimento de onda correspondente à máxima absorção. A e W constantes da equação (18); $\lambda_{\max }=$ máxima absorção ótica; $\Delta \lambda=$ largura da banda para $\mathrm{abs}_{\max } / 2$ que é igual a w/0.85.

\begin{tabular}{|c|c|c|c|c|c|c|}
\hline & Curva 1 & Curva 2 & Curva 3 & Curva 4 & Curva 5 & Curva 6 \\
\hline $\mathrm{abs}_{0}$ & 0.0 & 0.0 & 0.0 & 0.0 & 0.0 & 0.0 \\
\hline$\lambda_{\max }$ & 345.5 & 406.5 & 460.6 & 570.1 & 650.3 & 782.0 \\
\hline $\mathrm{W}$ & 45.7 & 27.2 & 79.7 & 70.1 & 83.5 & 78.7 \\
\hline A & 90.6 & 2.9 & 28.6 & 70.1 & 15.4 & 66.5 \\
\hline Área & 57.0 & 2.1 & 18.0 & 9.7 & 41.8 & 5.9 \\
\hline$\Delta \lambda$ & 53.5 & 32.0 & 94.0 & 82.5 & 98.0 & 92.5 \\
\hline Altura & 1.00 & 0.06 & 0.18 & 0.11 & 0.4 & 0.05 \\
\hline
\end{tabular}




\subsubsection{2-SOLUÇÃO DE OLIGÔMEROS USANDO CAPILAR DE RAIO 1.1mm}

A superficie do capilar foi exposta a uma câmara contendo ácido clorídrico concentrado $(\mathrm{N}=12 \mathrm{~N})$, durante 5 min. Foi gerada uma frente azul que caiu ficando armazenada no pequeno balão adaptado ao capilar, figura 3.4. Essa solução azul foi retirada do balão, e o seu espectro de absorção ótica medido, figura 4.22. O espectro decomposto deu origem aos parâmetros da tabela 13 .

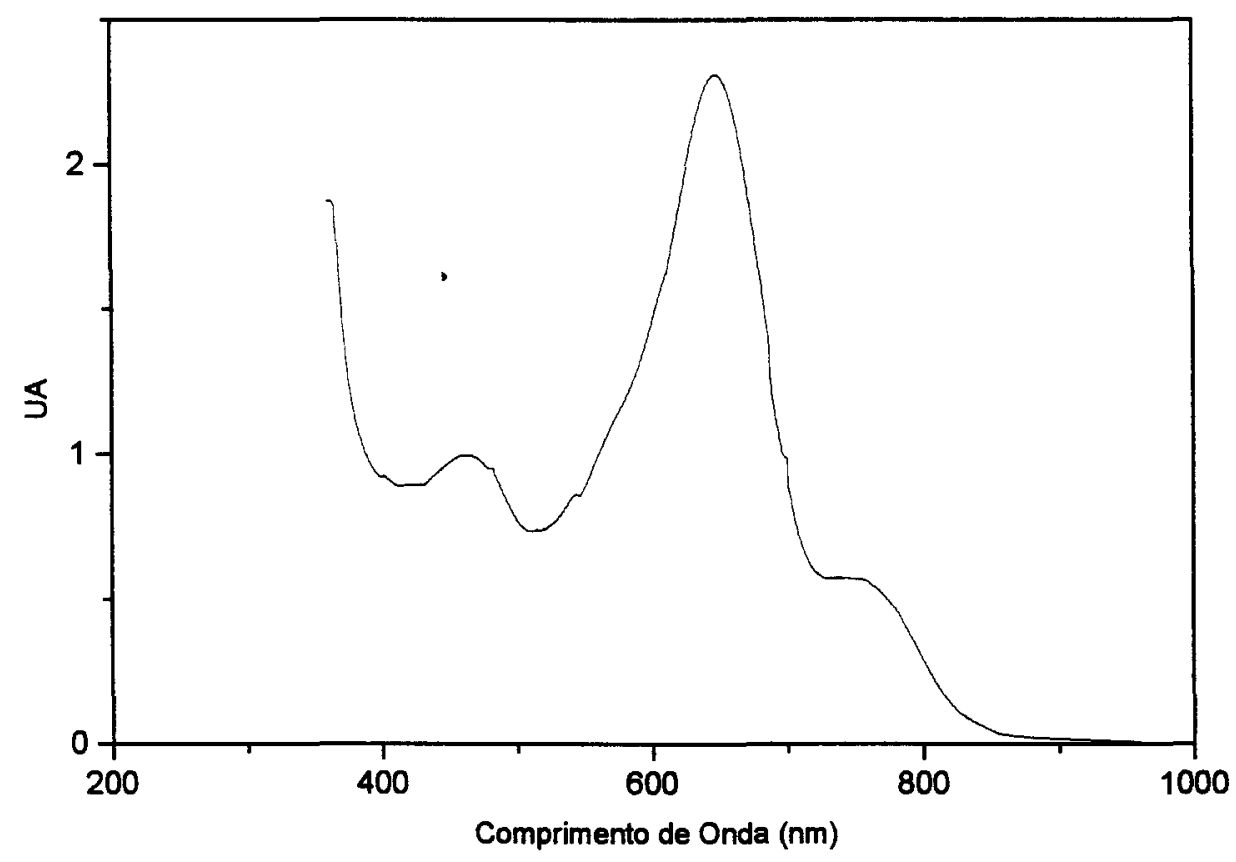

Figura 4.22-Espectro de absorção ótica UV-Visível da solução de cor azul, obtida através da catálise do álcool furfurílico exposto na superfície de capilares de borosilicato com raio de $1.1 \mathrm{~mm}$. A catálise foi realizada com vapor de ácido clorídrico $(C=12 N)$. Para referência foi usada uma solução de álcool furfurílico e DCM. 


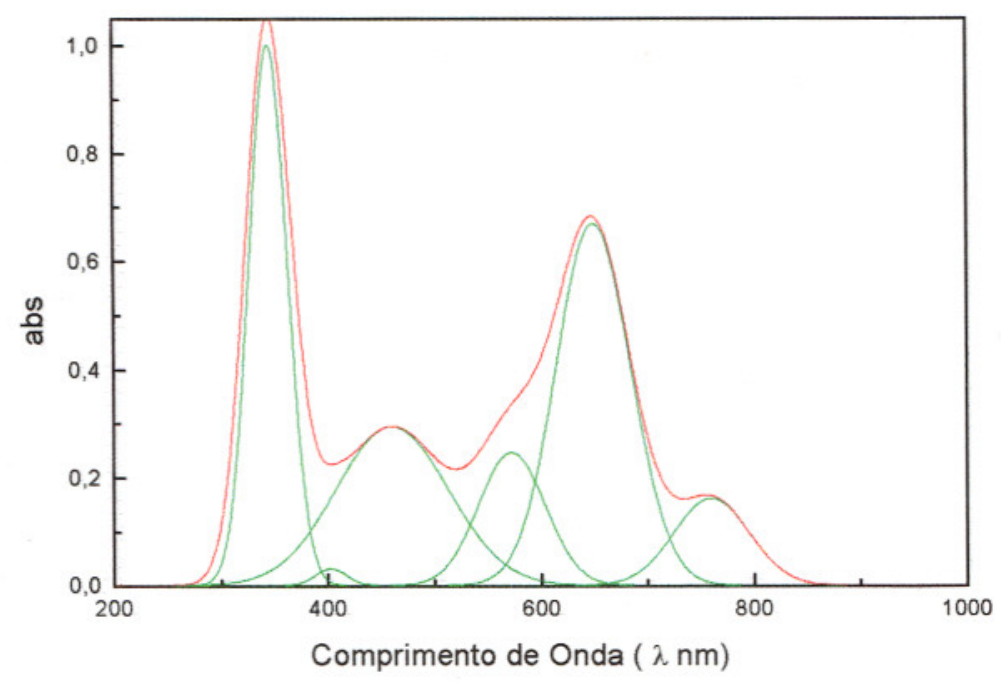

Figura 4.23-Decomposição em curvas Gaussianas do espectro de absorção ótica UV-Visível da solução de álcool furfurílico de cor azul. Solução obtida através da catálise ácida do álcool exposto na superfície do capilar de borosilicato de raio $1.1 \mathrm{~mm}$. Em verde, temos as Gaussianas construídas e normalizadas em função da maior absorção e em vermelho a sua soma.

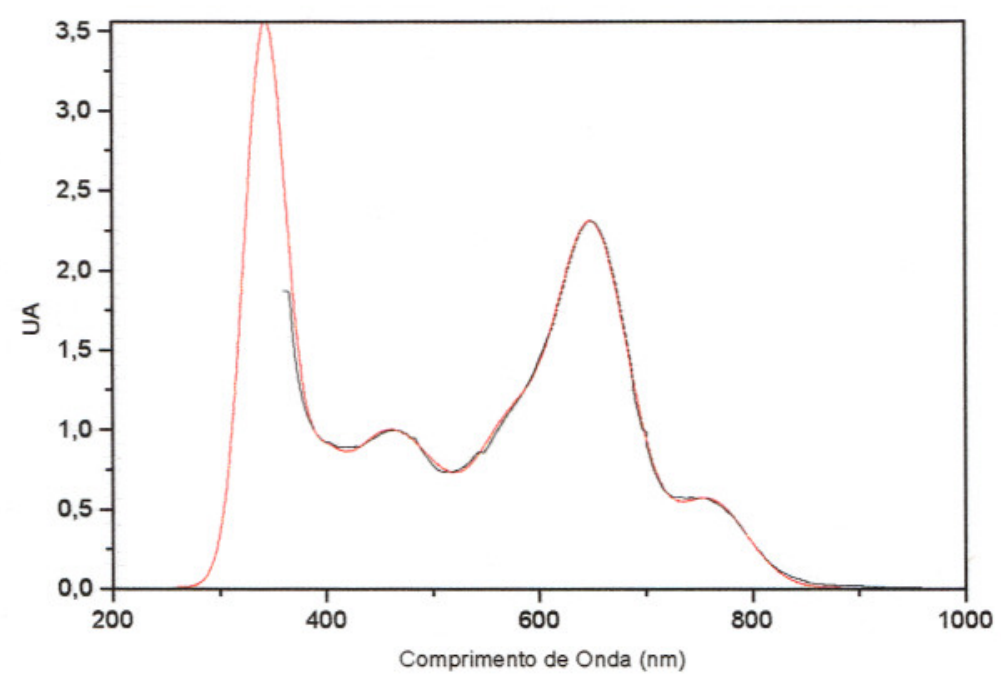

Figura 4.24-Comparação entre o espectro absorção ótica UV-Visível da solução de álcool furfurílico de cor azul, em preto. Solução obtida através da catálise ácida do álcool exposto na superfície do capilar de borosilicato de raio $0.85 \mathrm{~mm}$ e a soma das curvas Gaussianas obtidas através da decomposição do espectro original, em vermelho. 
Tabela 13-Valores relacionados com a construção das Curvas Gaussianas que estão em verde, obtidos a partir do espectro original, utilizando a equação (18).

\begin{tabular}{|c|c|c|c|c|c|c|}
\hline & Pico 1 & Pico 2 & Pico 3 & Pico 4 & Pico 5 & Pico 6 \\
\hline $\mathrm{abs}_{0}$ & 0.002 & 0.001 & 0.002 & 0.002 & 0.002 & 0.002 \\
\hline$\lambda_{\mathrm{c}}$ & 345.0 & 403.0 & 460.0 & 573.0 & 650.0 & 760.0 \\
\hline $\mathrm{W}$ & 58.0 & 29.1 & 105.2 & 62.5 & 70.1 & 70.7 \\
\hline $\mathrm{A}$ & 173.79 & 3.8 & 130.89 & 64.99 & 198.16 & 48.39 \\
\hline Área & 44.6 & 1.1 & 38.8 & 19.3 & 57.8 & 14.4 \\
\hline Tam Rel & 1.00 & 0.03 & 0.29 & 0.24 & 0.67 & 0.16 \\
\hline Largura & 42.5 & 42.0 & 124.0 & 73.5 & 82.5 & 83.5 \\
\hline
\end{tabular}

\subsubsection{3-POLIMERIZAÇĀO ATRAVÉS DO BORBULHAMENTO DO VAPOR ÁCIDO}

Passando gás nitrogênio em um frasco lavador de gás contendo ácido clorídrico, borbulhamos o vapor da solução de ácido no álcool furfurílico contido em um becker. Com isso foi formada uma solução azul. Foi medido então o espectro de absorção UV-Visivel da solução. Esse espectro pode ser visto na figura 4.25.

O espectro obtido diferencia-se em primeira aproximação dos espectros obtidos via catálise do álcool em sistemas capilares, através da sua forma. A decomposição desse espectro de absorção em curvas Gaussianas, mostra a presença de uma banda de absorção na região do infravermelho. Os parâmetros de construção das Gaussianas, bem como suas características estão na tabela 14. 


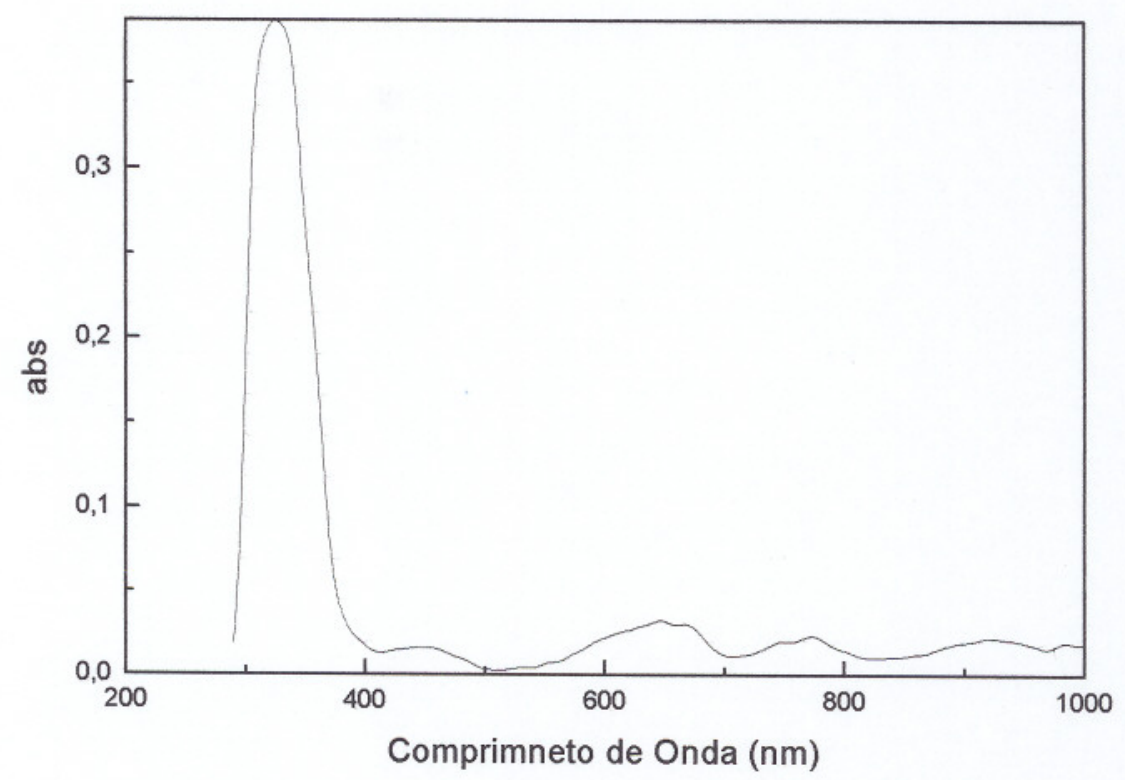

Figura 4.25-Espectro de absorção ótica UV-Visível da solução de cor azul, obtida através do borbulhamento de vapor de ácido clorídrico e gás nitrogênio. Para referência foi usada uma solução de álcool furfurílico e DCM.

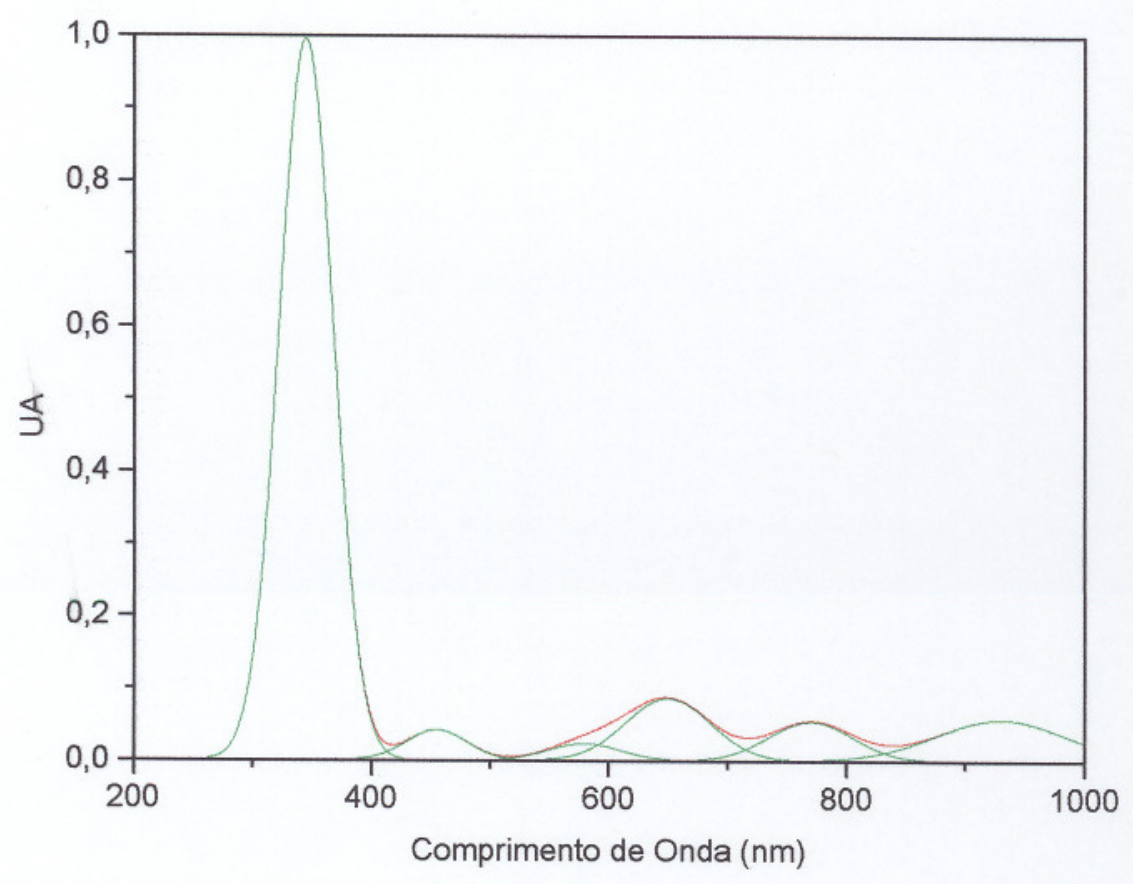

Figura 4.26-Decomposição em curvas Gaussianas do espectro de absorção ótica UV-Visível da solução de álcool furfurílico de cor azul. Solução obtida através do borbulhamento do ácido clorídrico com gás nitrogênio. Em verde, temos as Gaussianas construídas e normalizadas em função da maior absorção e em vermelho a sua soma. 


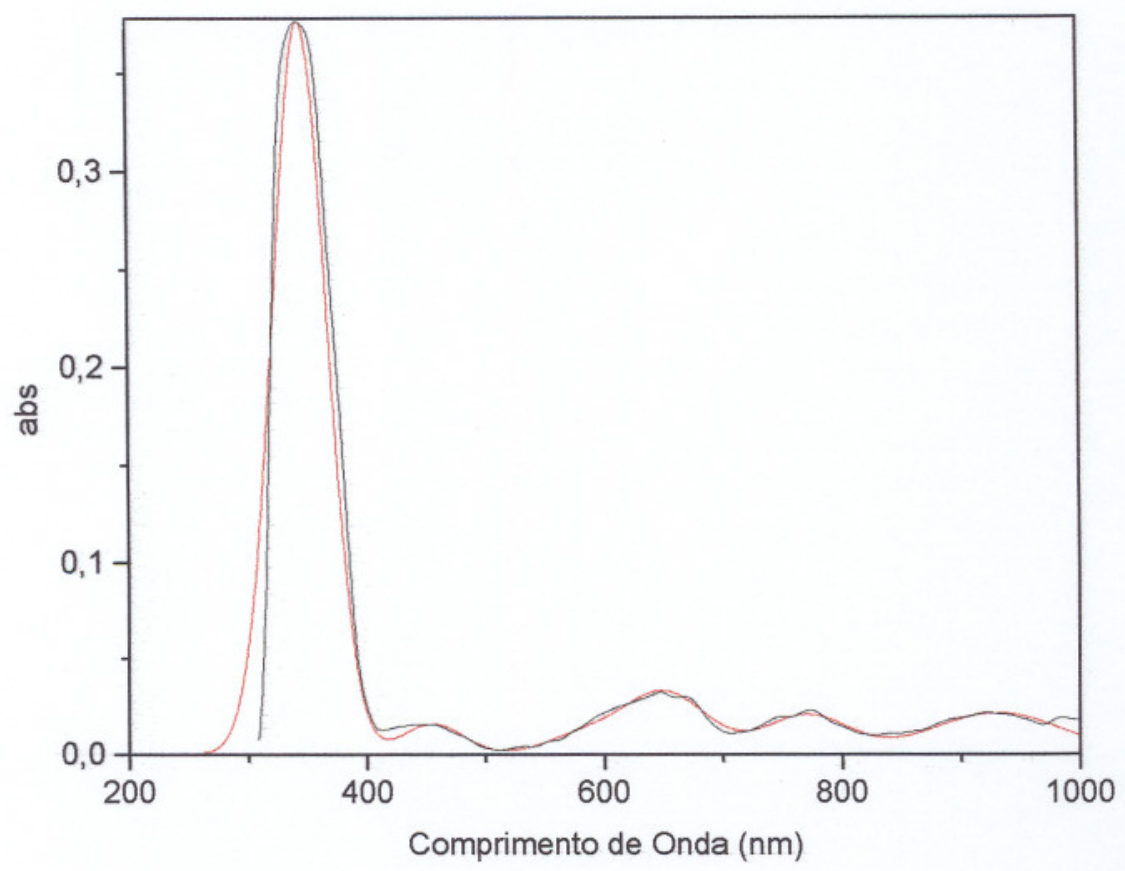

Figura 4.27-Comparação entre o espectro absorção ótica UV-Visível, em preto. E em vermelho temos a soma das curvas Gaussianas obtidas através da decomposição do espectro original.

Tabela 14-Parâmetros das Gaussianas obtidas da decomposição do espectro de absorção ótica da solução original, bem como suas características.

\begin{tabular}{|c|c|c|c|c|c|c|}
\hline & Curva 1 & Curva 2 & Curva 3 & Curva 4 & Curva 5 & Curva 6 \\
\hline abs $_{0}$ & 0.0 & 0.0 & 0.0 & 0.0 & 0.0 & 0.0 \\
\hline$\lambda_{\max }$ & 345.5 & 459.5 & 575.0 & 650.0 & 770.0 & 930.0 \\
\hline $\mathrm{W}$ & 45.7 & 50.9 & 60.7 & 71.5 & 70.6 & 110.1 \\
\hline A & 21.5 & 1.0 & 0.68 & 2.9 & 1.8 & 3.0 \\
\hline Área & 56.9 & 2.6 & 1.8 & 7.7 & 7.0 & 4.7 \\
\hline$\Delta \lambda$ & 53.5 & 59.5 & 71.5 & 84.5 & 129.5 & 83.0 \\
\hline Altura & 1.00 & 0.04 & 0.02 & 0.08 & 0.05 & 0.05 \\
\hline
\end{tabular}




\subsection{3-NEUTRALIZAÇÃO COM TRIETILAMINA}

A solução de cor azul obtida através da exposição do tubo capilar de $0.85 \mathrm{~mm}$ foi neutralizada usando-se uma solução de trietilamina em $\mathrm{DCM}(\mathrm{N}=6 \mathrm{~N})$. Após a neutralização a solução adquiriu cor laranja com o seguinte espectro de absorção, figura 4.28 .

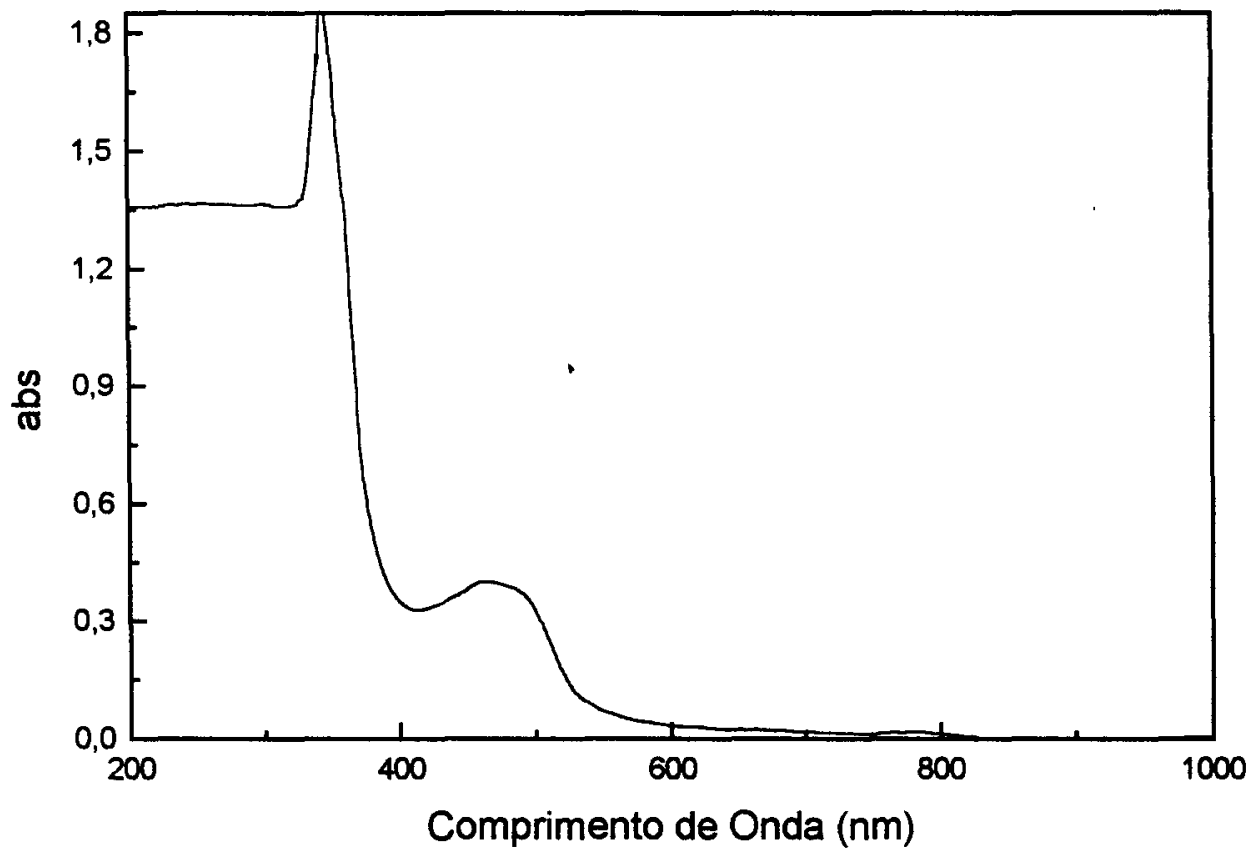

Figura 4.28-Espectro de absorção ótica UV-Visível da solução de cor laranja. Esse espectro foi obtido através da reação de neutralização da solução azul, obtida da exposição da interface álcool-ácido contida em um capilar de vidro, (raio igual a $0.85 \mathrm{~mm}$ ) com uma solução de trietilamina em DCM. Para referência foi usados uma solução de trietilamina, DCM e álcool furfurilico. 


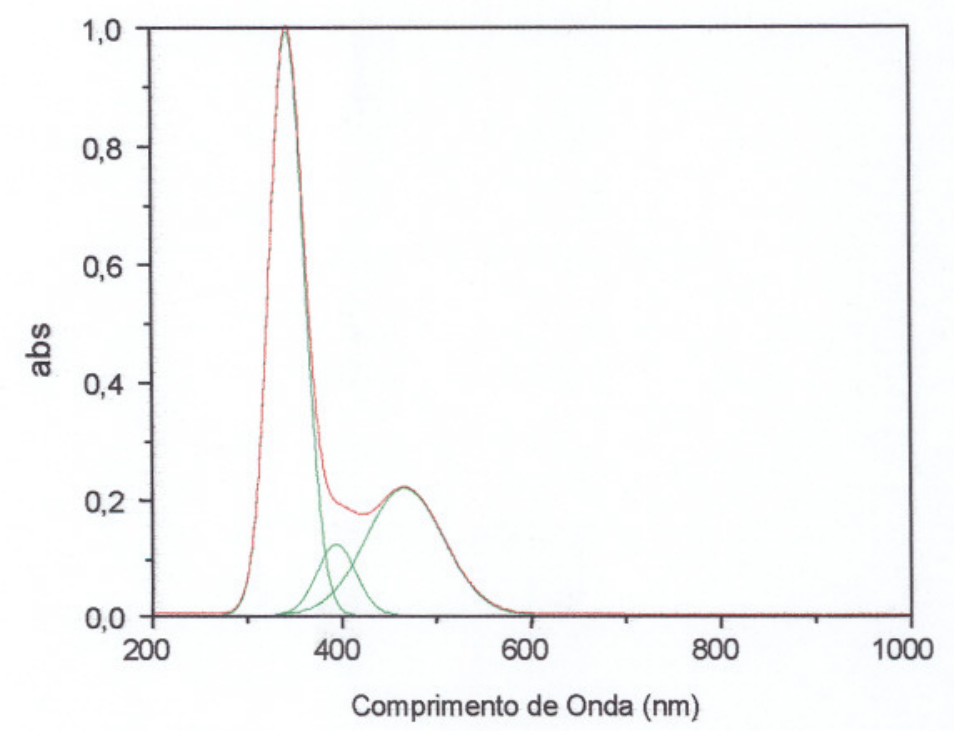

Figura 4.29-Decomposição em curvas Gaussianas do espectro de absorção ótica UV-Visível da solução laranja obtida após a neutralização com trietilamina. Em verde, temos as Gaussianas construídas e normalizadas em função da maior absorção e em vermelho a sua soma.

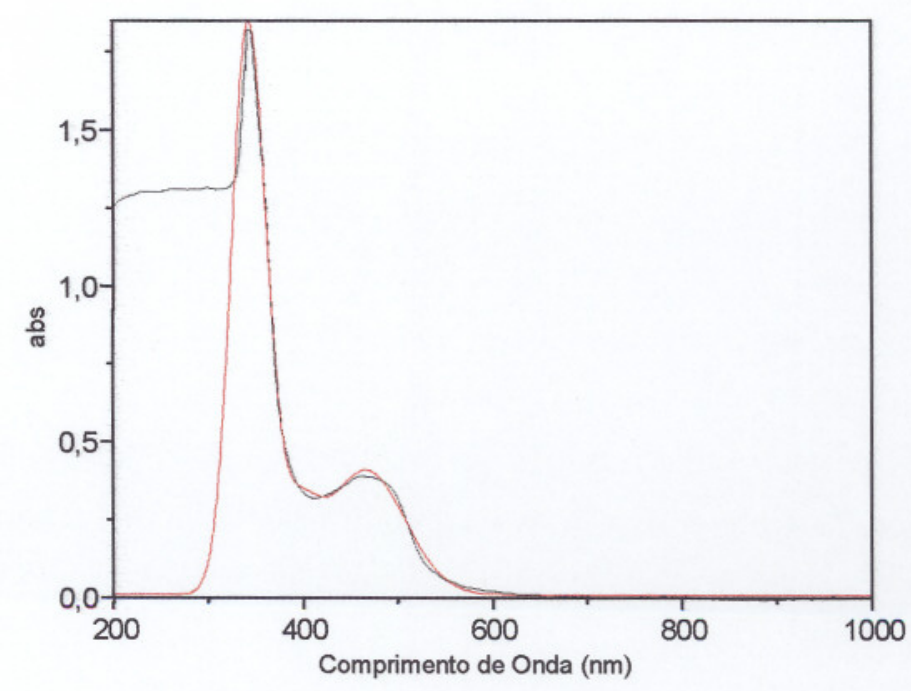

Figura 4.30- Comparação do espectro de absorção ótica UV-Visível da solução laranja obtida após a neutralização com trietilamina. Em preto, temos o espectro de absorção óptica e em vermelho a sua soma. 
Tabela 15-Parâmetros de construção das curvas Gaussianas obtidas a partir da solução neutralizada de álcool furfurílico.

\begin{tabular}{|c|c|c|c|}
\hline & Curva 1 & Curva 2 & Curva 3 \\
\hline abs $_{0}$ & 0.002 & 0.002 & 0.002 \\
\hline$\lambda_{\max }$ & 345.0 & 395.0 & 467.0 \\
\hline $\mathrm{A}$ & 84.3 & 11.6 & 41.6 \\
\hline $\mathrm{W}$ & 36.9 & 41.1 & 82.7 \\
\hline Área & 46.9 & 7.2 & 23.6 \\
\hline Tam Rel & 1.00 & 0.12 & 0.22 \\
\hline Largura & 43.5 & 48.5 & 97.5 \\
\hline
\end{tabular}

\subsection{4- SOLUÇÃO DE AF DE COR AMARELA}

O álcool furfurílico deixa de ser incolor degradando-se pela ação da luz e do calor $[4,6,19]$. Esse processo dá origem à cor amarela do álcool furfurílico estocado [4]. A intensidade dessa cor amarela aumenta com o tempo. O espectro de absorção deste líquido amarelo está mostrado na figura 4.31 e a sua análise cromatográfica na tabela 16. Nele podemos ver a presença de uma banda larga, com máximo em $360 \mathrm{~nm}$. 


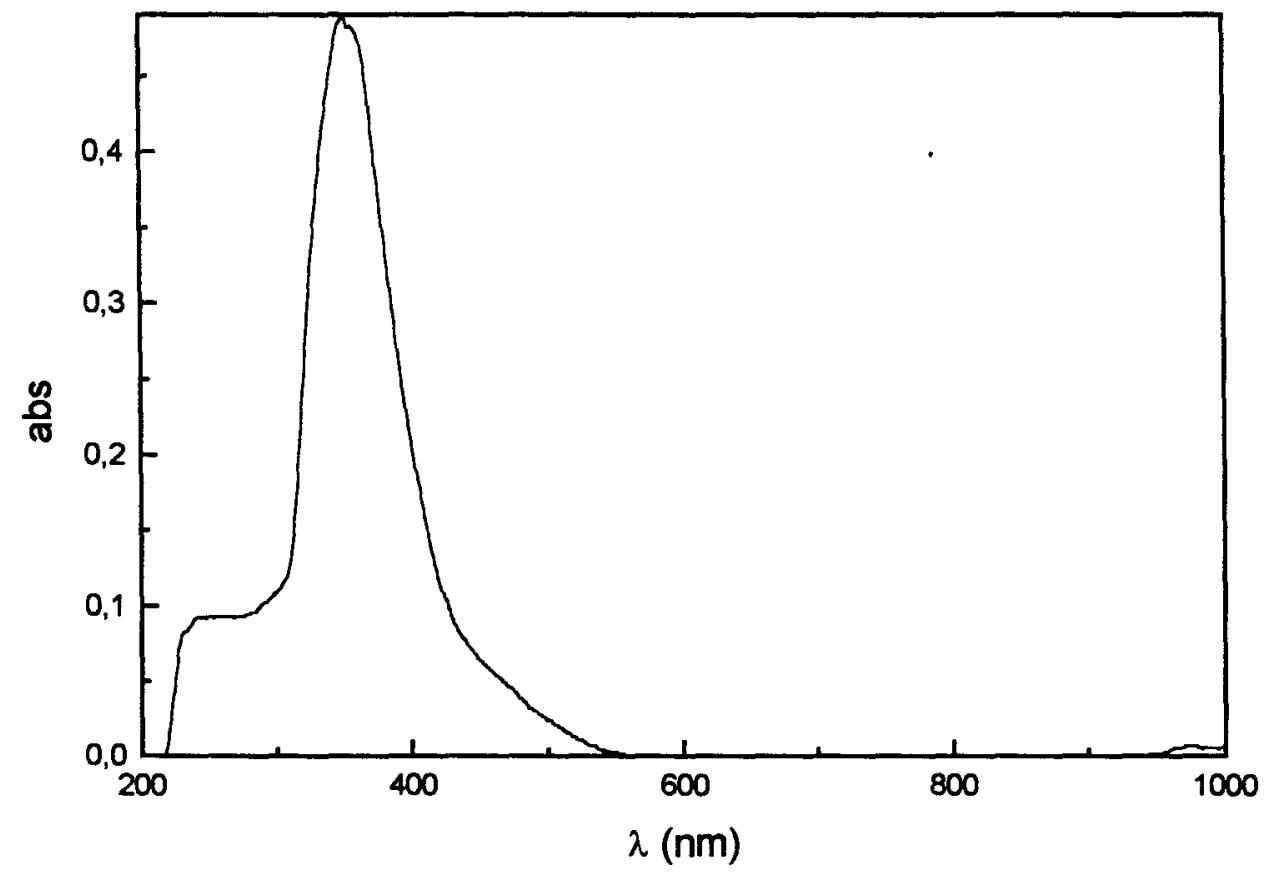

Figura 4.31- Espectro de absorção ótica do AF em solução quando a mesma apresenta-se amarelada. Para referência foi usada uma cuba de $10 \mathrm{~mm}$, contendo AF recém destilado.

Tabela 16- Composição da solução de cor amarela do Álcool Furfurílico.

\begin{tabular}{|c|c|}
\hline Tempo de Retenção (mim) & Concentração (\%) \\
2.75 & 98.41 \\
\hline 3.08 & 0.21 \\
\hline 5.82 & 0.28 \\
\hline 9.50 & 0.24 \\
\hline 11.59 & 0.56 \\
\hline 13.05 & 0.30 \\
\hline
\end{tabular}

Estes resultados mostram que a concentração de álcool furfurílico diminuiu em $1.15 \%$, e outros compostos foram formados a partir do AF, tabela 16. Alguns desses picos já são conhecidos em função do seu tempo de retenção. O pico com TR 
de $2.75 \mathrm{~min}$ é do álcool furfurílico e aquele com $3.08 \mathrm{mim}$ e $5.82 \mathrm{mim}$ são desconhecidos. O pico com TR de 9.5 min foi atribuído por exclusão a água, na análise cromatográfica do álcool incolor, tabela 3. O pico com TR em 11.59 min é atribuído ao dímero do álcool furfurílico na forma não conjugada, figura 4.7.

A análise do pico com TR 13.05 min através de espectroscopia de massa resultou no espectro da figura 4.32 .

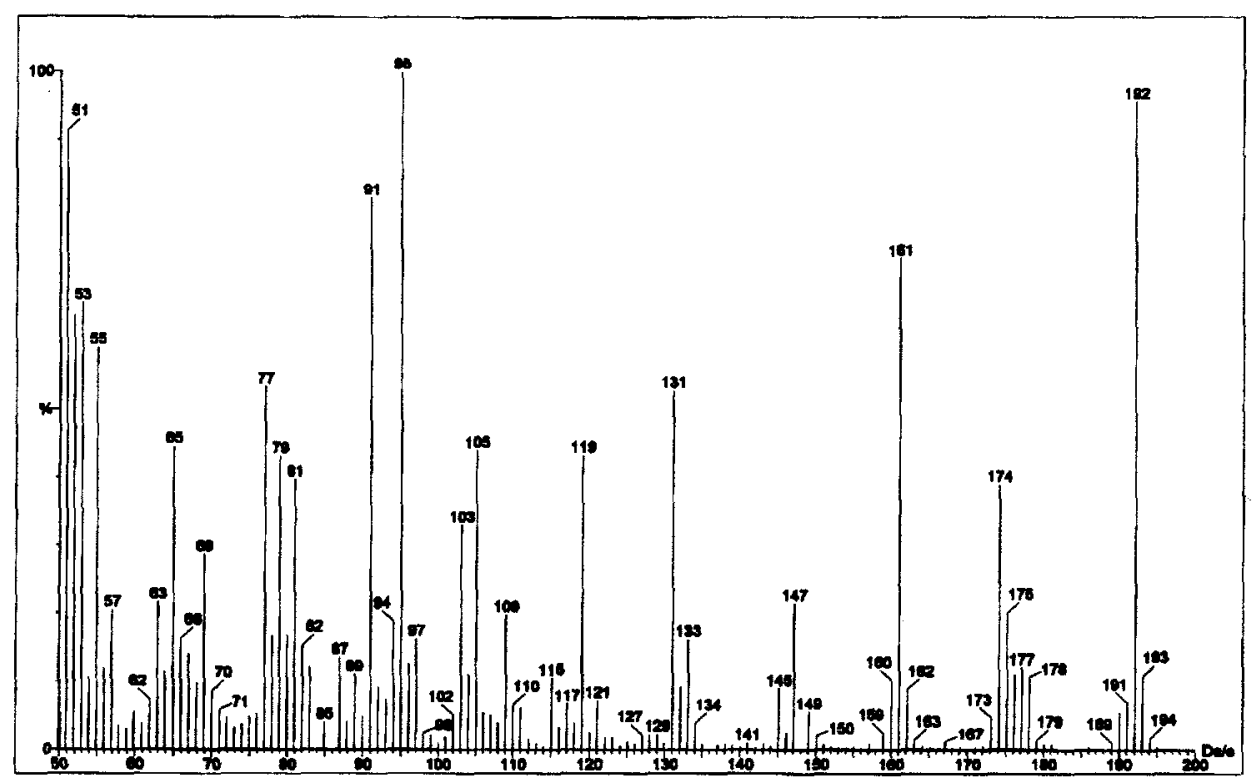

Figura 4.32-Espectro de massa obtida através da técnica CG-MS, onde foi selecionado para análise o pico com TR de 13.05min.

No espectro podemos ver as múltiplas fragmentações da mesma molécula. $\mathrm{O}$ espectro de massa mostra um pico em $192 \mathrm{~m} / \mathrm{z}$, que pode ser relacionado com o pico do íon molecular com massa molecular igual [26]. Dentre as possíveis estruturas, temos:<smiles>O=C(O)c1ccc(Cc2ccco2)o1</smiles> 
Os picos resultantes da fragmentação podem ser relacionados aos seguintes produtos contidos na tabela 17 .

Tabela 17-Relação entre os fragmentos obtidos no espectro de massa e sua possivel estrutura

\begin{tabular}{|l|c|}
\hline & Massa do ion (g/ml) \\
\hline
\end{tabular}

Assim, podemos ver que na solução de cor amarela do álcool furfurílico temos a presença de um composto com propriedades ácidas que deve estar associados ao processo de degradação temporal. Esse derivado foi formado pela ação do tempo sob as condições de estocagem do álcool, sendo que a sua formação propiciada pela presença de moléculas de água.

As moléculas de água induzem a abertura do anel [4]. 0 produto resultante dessa reação acelera o processo degradação do álcool, uma vez que é uma espécie mais ácida. Essas moléculas estão presentes nos primeiros estágios de polimerização do álcool. 


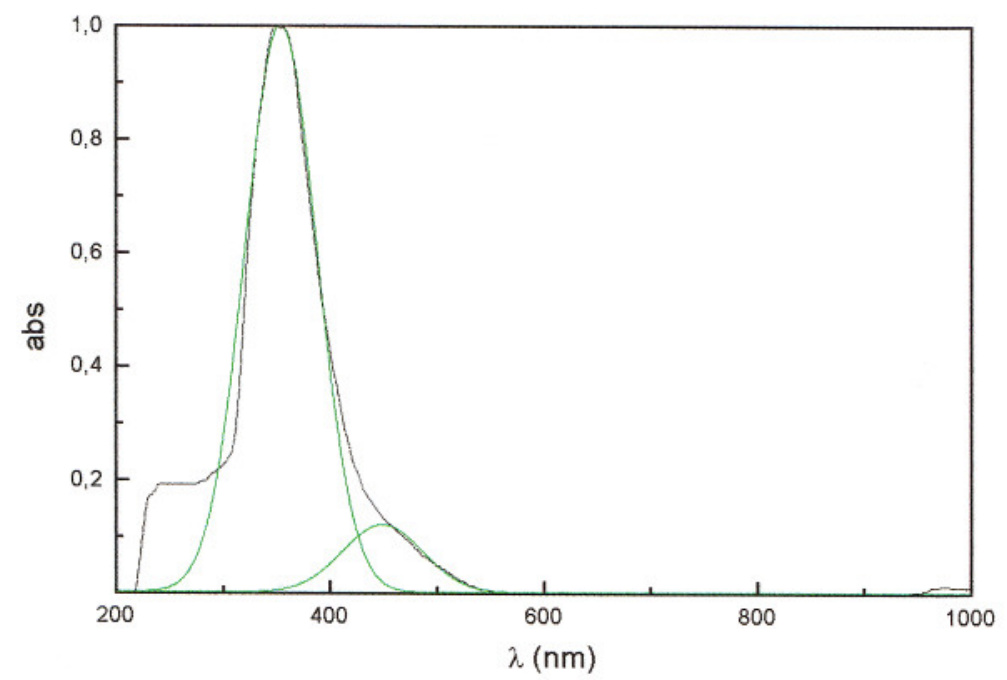

Figura 4.34-Decomposição do espectro de absorção ótica em Gaussianas da solução amarela de álcool furfurílico, onde em verde podemos ver a duas curvas e em preto a curva experimental normalizada.

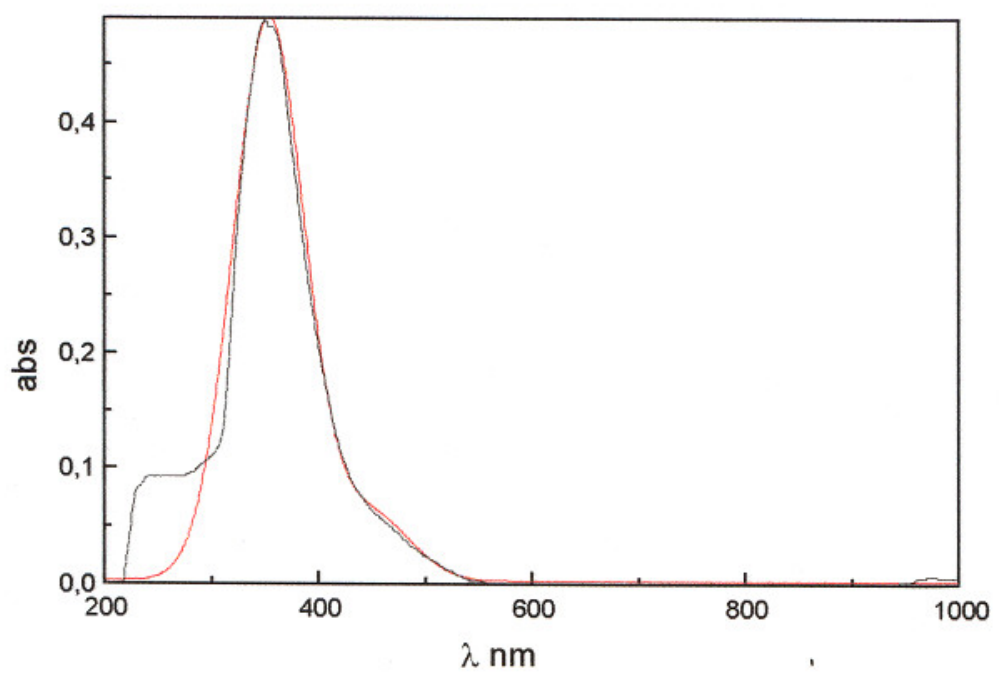

Figura 4.35-Comparação entre o espectro de absorção ótica medido em preto, e a soma de duas Gaussianas, em vermelho, obtidas através da decomposição do espectro da solução de álcool furfurílico amarelo original. 
Tabela 18-Parâmetros de construção das curvas Gaussianas obtidos através da decomposição do espectro original.

\begin{tabular}{|c|c|c|}
\hline & Curva 1 & Curva 2 \\
\hline abso & 0 & 0 \\
\hline$\lambda_{\max }(\mathrm{nm})$ & 354.0 & 450.0 \\
\hline $\mathrm{W}(\mathrm{nm})$ & 67.04 & 75.13 \\
\hline $\mathrm{A}$ & 40.7 & 5.4 \\
\hline Área & 85.7 & 12.8 \\
\hline Altura & 1.00 & 0.12 \\
\hline$\Delta \lambda(\mathrm{nm})$ & 79 & 89.5 \\
\hline
\end{tabular}

Do acima exposto, podemos concluir que durante a degradação do álcool furfurílico armazenado formam-se, principalmente, compostos que dão origem às bandas de absorção em $345 \mathrm{~nm}$ e $460 \mathrm{~nm}$. A banda de $354 \mathrm{~nm}$ é atribuída aos dímeros enquanto a $450 \mathrm{~nm}$ ainda não pode ser atribuída a um composto definido apesar de estar associada ao dímero. As demais conclusões referentes aos oligômeros coloridos serão abordadas posteriormente. 


\section{4-TAMANHO E ESTRUTURA}

O resultado da cromatografia gasosa para o álcool furfurílico incolor mostra a presença de dois compostos diferentes do álcool, em concentração pequena, um com o tempo de retenção 11.59 min. Esse composto também está presente na solução amarela do álcool, porém em maior concentração quando comparado ao da tabela 16. Analisando por espectroscopia de massa este composto revelou-se como sendo o dímero. Este dímero absorve no visivel, pois apresenta fluorescência quando irradiado por um laser, figura 4.5.

A presença de dímeros ocorre sem que haja a presença de catalisador ácido. As duas moléculas de monômero reagem formando os dímeros e liberando água, eessa reação pode ser induzida pela temperatura e/ou radiação. Assim em $345 \mathrm{~nm}$ existem dímeros sem estarem associados ao catalisador. Sabe-se que a presença de ácido afeta a formação de polímero e está associado em polímeros condutores com a presença de bandas na região do visível [6].

Como mostra a figura 4.36, para o mesmo número de dímeros podemos dizer que a relação oligômero/dímeros é bem maior nos capilares. Entretanto as condições de formação são diferentes. Nos capilares a concentração de dímeros e ácido no momento de formação dos oligômeros (isto é na interface) é muito mais alta do que no borbulhamento, o que não leva a formação de moléculas mais longas ou de termofixos. Portanto deve haver um mecanismo que protege os oligômeros menores. O mecanismo capaz de dar essa proteção deve também esclarecer a queda desses oligômeros.

Existe uma forte absorção em $345 \mathrm{~nm}$ comum a todos os espectros das soluções coloridas do álcool furfurílico. Assim como essa banda, outra em 460nm 
também pode ser observada em todos os espectros óticos das soluções coloridas. Essa banda, no entanto é menos intensa que a de $345 \mathrm{~nm}$. O álcool furfurílico catalisado por ácido quer através da interface álcool-ácido dentro dos capilares quer através de borbulhamento do vapor de ácido, dá um espectro ótico que decomposto gera um conjunto de curvas Gaussianas comuns sob esse espectro. Essas curvas têm os seguintes máximos: $345 \mathrm{~nm}, 460 \mathrm{~nm}, 570 \mathrm{~nm}, 650 \mathrm{mn}$ e $770 \mathrm{~nm}$.

A banda em $345 \mathrm{~nm}$ é a que sempre apresenta maior absorção. Essa banda foi normalizada, e sua altura passou a ser igual a um para todos os espectros. A sua área varia acompanhando a largura da banda à meia-altura.

Assim através da tabela 19 podemos comparar a área sob as curvas e na tabela 20 , a altura relativa entre os mạximos de absorção.

Tabela 19-Relação das alturas sob as curvas Gaussianas representadas pelo seu comprimento de onda na máxima absorção, nas diferentes soluções de álcool furfurílico.

\begin{tabular}{|c|c|c|c|c|c|c|c|}
\hline \multirow{2}{*}{ Área } & \multicolumn{7}{|c|}{ Comprimento de Onda (nm) } \\
\cline { 2 - 8 } & 345 & 406 & 460 & 570 & 650 & 770 & 930 \\
\hline $0.85 \mathrm{~mm}$ & 57.0 & 2.1 & 18.0 & 9.7 & 41.8 & 5.9 & - \\
\hline $1.1 \mathrm{~mm}$ & 44.6 & 1.1 & 38.8 & 19.3 & 57.85 & 14.35 & - \\
\hline borbulhado & 56.9 & - & 2.6 & 1.8 & 7.7 & 7.0 & 4.7 \\
\hline Neutralizado & 46.9 & 7.2 & 23.6 & - & - & - & - \\
\hline Amarelo & 85.7 & - & 12.8 & - & - & - & - \\
\hline
\end{tabular}


Tabela 20-Relação das alturas sob as curvas Gaussianas representadas pelo seu comprimento de onda na máxima absorção, nas diferentes soluções de álcool furfurílico.

\begin{tabular}{|c|c|c|c|c|c|c|c|}
\hline \multirow{2}{*}{ Altura } & \multicolumn{7}{|c|}{ Comprimento de Onda (nm) } \\
\cline { 2 - 8 } & 345 & 406 & 460 & 570 & 650 & 770 & 930 \\
\hline $0.85 \mathrm{~mm}$ & 1.00 & 0.06 & 0.22 & 0.11 & 0.4 & 0.05 & - \\
\hline $1.1 \mathrm{~mm}$ & 1.00 & 0.03 & 0.29 & 0.24 & 0.67 & 0.16 & - \\
\hline borbulhado & 1.00 & - & 0.04 & 0.02 & 0.08 & 0.05 & 0.05 \\
\hline Neutralizado & 1.00 & 0.12 & 0.22 & - & - & - & - \\
\hline Amarelo & 1.00 & - & 0.12 & - & - & - & - \\
\hline
\end{tabular}

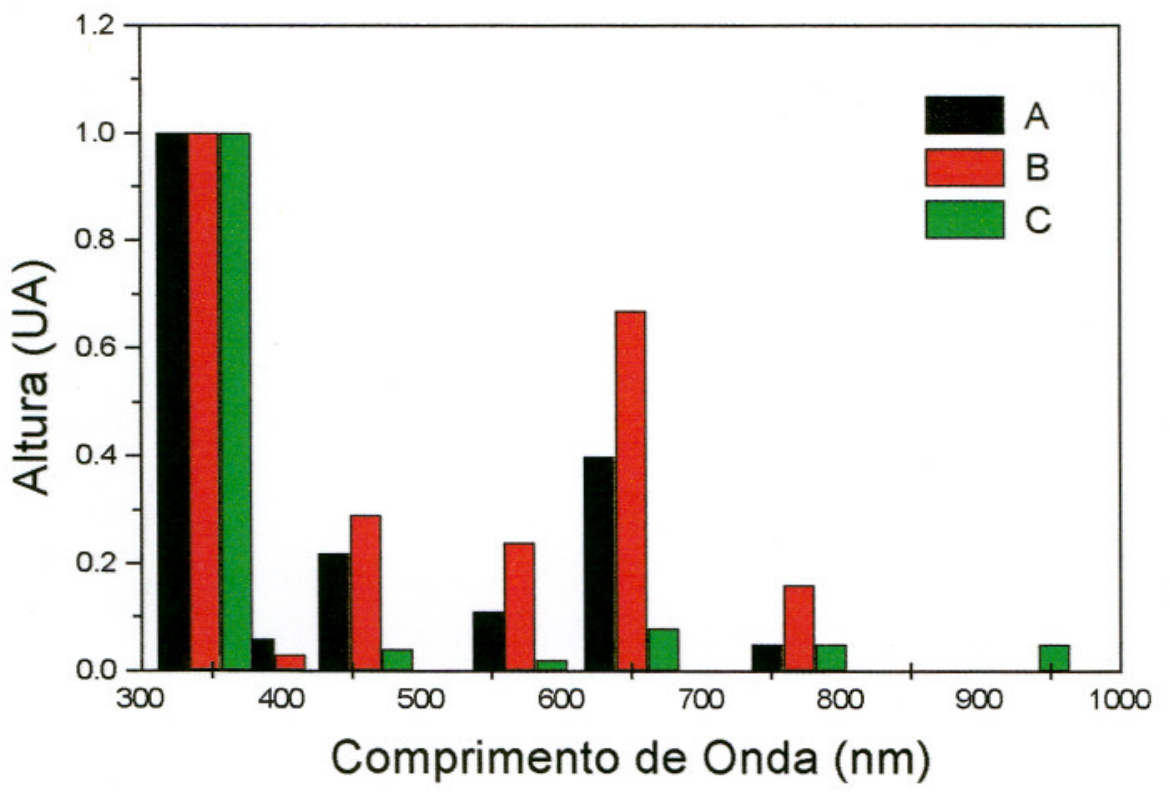

Figura 4.36-Relação entre as alturas relativas aos máximos das curvas Gaussianas obtidas, através da decomposição dos espectros de absorção ótica das soluções de oligômeros do álcool furfurílico. Aonde $\mathrm{A}$ se refere às alturas dos máximos para o capilar de $1.10 \mathrm{~mm}$ de raio. Em $\mathrm{B}$ os máximos para o capilar de $0.85 \mathrm{~mm}$ de raio e em C os máximos para a catálise através de borbulhamento.

Os resultados das medidas de absorção óptica estão resumidos na tabela 19 e na figura 4.36. As análises químicas realizadas indicam que a banda de absorção em 
345nm pertence a dímeros do AF. A neutralização da solução azul produzida no capilar de $0,85 \mathrm{~mm}$ de raio mostra que tanto essa banda como a de $460 \mathrm{~nm}$ não se referem a oligômeros dopados pelo próton, diferentemente das outras bandas. $\mathrm{O}$ processo de decomposição dos espectros em curvas Gaussianas, bem como a presença de outros centros com absorção nessa faixa de comprimento de onda de $345 \mathrm{~nm}$ torna dificil o processo de normalização. Isto pode ser comprovado através da área sob o pico de $345 \mathrm{~nm}$. A sua meia largura varia com o processo de preparação. Estimamos correlação de $30 \%$ para os dados da tabela 19 , valor este obtido para a mesma correlação em sistemas conhecidos, como o $\beta$-caroteno. Dentro dessa margem de erro podemos afirmar que a banda em $460 \mathrm{~nm}$ está relacionada com a de $345 \mathrm{~nm}$ se considerarmos todos os rądicais metila presentes, inclusive o de todos os oligômeros Pode-se, portanto, imaginá-la como sendo devida ao radical metila que faz a ligação entre os anéis furânicos. A formação da banda de $460 \mathrm{~nm}$ nos capilares de $1,10 \mathrm{~mm}$ e $0,85 \mathrm{~mm}$ de diâmetro mostra uma mesma proporção com os seus dímeros, percebe-se que a neutralização com a trietilamina não mudou essa relação. $\mathrm{Na}$ polimerização por borbulhamento, entretanto, a proporção da banda de $460 \mathrm{~nm}$ é completamente diferente, estando bem abaixo do valor esperado, o que pode ser devido à pequena concentração de oligômeros.

Quanto às bandas de $570 \mathrm{~nm}, 650 \mathrm{~nm}, 770 \mathrm{~nm}$ e $930 \mathrm{~nm}$, todas resultantes da dopagem dos oligômeros pelo próton, observa-se o seguinte comportamento. Nos três casos mostrados na tabela e na figura 4.36 a banda de $650 \mathrm{~nm}$ é a mais intensa. A banda de 930nm apresenta um comportamento peculiar. Está ausente nos polímeros preparados no capilar de $1,1 \mathrm{~mm}$ de raio, mostra intensidade comparável as outras bandas presentes na solução preparada por borbulhamento e intensidade muito pequena na solução preparada no capilar de $0,85 \mathrm{~mm}$. 
bandas presentes na solução preparada por borbulhamento e intensidade muito pequena na solução preparada no capilar de $0,85 \mathrm{~mm}$.

A banda de $570 \mathrm{~nm}$ guarda uma relação constante com a de $650 \mathrm{~nm}$ podendo ser uma banda satélite desta última ou um outro oligômero. As bandas de $770 \mathrm{~nm}$ e 930nm devem ser devidas a oligômeros de maior número de meros. É bem conhecido que o deslocamento das bandas para o infravermelho, é devido ao aumento do comprimento das unidades conjugadas do polímero $[8,9,31]$.

Considerando-se que o processo de borbulhamento homogeneiza muito mais a solução dos oligômeros formados bem como facilita a dispersão do $\mathrm{HCl}$, parece intrigante que o processo de borbulhamento gere uma maior concentração relativa da banda de 930nm atribuída aos oligômeros de cadeias maiores. A eficiência na formação dos oligômeros neste caso é menor como se pode verificar pelo gráfico da figura 4.36. Quando a polimerização se dá nos capilares a concentração de ácido na interface $\mathrm{AF} / \mathrm{HCl}$ é muito elevada produzindo alta concentração de oligômeros na superfície. Seria de se esperar, portanto, também a formação de oligômeros com absorção em comprimentos maiores. Entretanto, pelo contrário, as intensidades das bandas devido aos oligômeros de maior comprimento diminuem acentuadamente. Nos capilares a formação dos oligômeros correspondentes a absorção em $650 \mathrm{~nm}$ apresentam elevada eficiência quando comparadas com a concentração de dímeros $(345 \mathrm{~nm})$.

Esses resultados nos conduzem a discutir os possíveis mecanismos capazes de proteger os oligômeros formados na superfície de forma a não aumentarem o seu comprimento. Um desses mecanismos reside no fato dos oligômeros, uma vez formados, saírem da interface onde estão expostos ao vapor de ácido, caindo para o interior do capilar. Esse mecanismo explica porque o capilar de maior diâmetro, e, 
portanto de maior velocidade de queda, apresentou maior concentração de oligômeros de menor número de meros. De qualquer forma para que haja queda é necessário que alguma forma de aglomeração ocorra.

A formação desses oligômeros é acompanhada da formação de água, figura 2.3. Dessa forma a carga eletrônica se distribuirá sobre a cadeia criando um dipolo entre o carbocátion e os íons $\mathrm{Cl}^{-}$, possivelmente ligados a água que é um produto da reação de polimerização. A conformação do aglomerado de oligômeros que minimiza a energia ainda está em estudo. Entretanto, qualquer que seja essa configuração e quais forças a determinam, a formação de agregados está garantida.

Nessa configuração um dos dois sítios ativos para polimerização do $\mathrm{AF}$ tornou-se menos ativo reduzindo a probabilidade da reação de polimerização. A proteção assim gerada é aquela que corresponde a absorção em $650 \mathrm{~nm}$. O número de meros nesse oligômero pode ser estimado, como veremos abaixo.

Os oligômeros presentes em maior concentração na película que está caindo desempenham um papel muito importante. Moléculas de cadeia curta têm menor possibilidade de vir a constituir a película formada na interface, ou de se organizarem formando estruturas complexas do tipo vesículas e/ou micelas.

Os espectros de absorção óptica de moléculas de cadeia conjugada são conhecidas e estudadas há longo tempo [8,9]. A molécula do $\beta$-caroteno e do licopeno, que apresentam uma estrutura conjugada, de tamanho semelhante aos oligômeros deste trabalho tem tido a absorção óptica no UV-visível calculada por métodos simples, além de outros métodos teóricos como o LCAO. Entre os métodos simples há um empírico desenvolvido por Kuhn e Fiser $[8,9,31,32]$ sobre o qual não vamos nos ater devido a peculiaridades do núcleo furânico. O modelo mais simples 


$$
\begin{aligned}
& \mathrm{U}=0 \rightarrow 0<\mathrm{X}<1 \\
& \mathrm{U}=+\infty\left\{\begin{array}{l}
\mathrm{X} \leq 0 \\
\mathrm{X} \geq 1
\end{array}\right.
\end{aligned}
$$

Sabe-se que essas condições se cumprem com menor ou maior acerto dependendo dos detalhes da cadeia conjugada - cíclicas ou lineares, a natureza dos átomos ligados na cadeia, radicais ligados externamente à cadeia e suas terminações. Por essa razão há necessidade de correções do modelo ou aplicá-lo em sistemas com diferentes números de mero.

No modelo do elétron numa caixa unidimensional de comprimento $L$, o valor do comprimento de onda da luz para absorção máxima, $\lambda_{\max }$, é dado por:

$$
\lambda_{\max }=\frac{8 \mathrm{mc}}{\mathrm{h}} \frac{\mathrm{L}^{2}}{2 \mathrm{~N}+1}
$$

Aonde, $\mathrm{m}=$ massa do elétron, $\mathrm{c}=$ velocidade da luz, $\mathrm{h}=$ constante de Planck, $\mathrm{N} \mathrm{o}$ número de ligações $\pi$ conjugadas presentes na cadeia em estudo.

A aplicação desse modelo ao $\beta$-caroteno, cujo $\lambda_{\max }=480 \mathrm{~nm}$, produz um valor para $\mathrm{L}$ de $1,83 \mathrm{~nm}$ enquanto o valor real é de $2,90 \mathrm{~nm}$, portanto, um desajuste de $37 \%$ para menor.

$$
\mathrm{L}^{2}=\frac{\mathrm{h} \lambda_{\max }(2 \mathrm{~N}+1)}{8 \mathrm{mc}}
$$


Aplicando-se esse modelo as bandas de absorção dos oligômeros cujo 'max são $570 \mathrm{~nm}, 650 \mathrm{mn}, 770 \mathrm{~nm}$ e $930 \mathrm{~nm}$ obtêm-se os valores indicados na tabela 21 . Nessa aplicação se faz necessário assumir tentativamente um valor para $\mathrm{N}$, o número de ligações, portanto, o número de meros envolvidos. $\mathrm{O}$ valor de Leal $=\mathrm{Nx} 0,13$ $+(\mathrm{N}+1) 0,146 \mathrm{~nm}$ aonde 0,136 e 0,146 são os comprimentos em nanômetros das ligações duplas e simples, respectivamente. Os resultados mostram que o erro do valor calculado é sempre para menor em relação ao experimental e muito próximo daquele achado para o $\beta$-caroteno.

Tabela 21-Avaliação do tamanho da conjugação $(\mathrm{N})$, com relação ao comprimento da cadeia $\mathrm{L}$ estimado e o observado, com os respectivos erros.

\begin{tabular}{|c|c|c|c|c|}
\hline $\mathrm{N}$ & 12 & 17 & 22 & 7 \\
\hline$\lambda_{\max (\mathrm{nm})} \mathrm{nm}$ & 650 & 770 & 930 & 577 \\
\hline Meros & 5 & 7 & 9 & 3 \\
\hline L calc (nm) & 2.22 & 2.86 & 3.56 & 1.62 \\
\hline L real (nm) & 3.52 & 4.92 & 6.33 & 2.10 \\
\hline$\Delta \mathrm{L} /$ Lreal & $37 \%$ & $42 \%$ & $44 \%$ & $23 \%$ \\
\hline
\end{tabular}

Tabela 22-Avaliação do tamanho da conjugação $(\mathrm{N})$, com relação ao comprimento da cadeia estimado e o observado, com os respectivos erros.

\begin{tabular}{|c|c|c|c|c|}
\hline$\lambda_{\max }$ & $650 \mathrm{~nm}$ & $770 \mathrm{~nm}$ & $930 \mathrm{~nm}$ & $577 \mathrm{~nm}$ \\
\hline Meros & 7 & 9 & 11 & 5 \\
\hline $\mathrm{N}$ & 17 & 22 & 27 & 12 \\
\hline L calc (nm) & 2.63 & 3.24 & 3.94 & 1.45 \\
\hline L real (nm) & 4.92 & 6.33 & 8.64 & 3.52 \\
\hline$\Delta \mathrm{L} / \mathrm{L}$ real & $46 \%$ & $49 \%$ & $54 \%$ & $60 \%$ \\
\hline
\end{tabular}


A tabela 22 mostra que os desvios crescem se o número de meros atribuídos a cada um dos valores de $\lambda_{\max }$ é maior. É interessante notar a boa concordância obtida, considerando-se somente oligômeros com número ímpar de meros. Isto pode ser atribuído à instabilidade dos compostos com ligação dupla quando associada a uma hidroxila. Quando esse tipo de configuração é desenvolvido há formação de compostos carbonílicos. Esse compostos carbonílicos são gerados a partir da tautomerização da estrutura enólica, formada da conjugação sobre o carbono ligado ao grupo hidroxílico. A presença de ácido no meio desloca o equilíbrio para formação de compostos carbonílicos do tipo aldeído ou cetona.

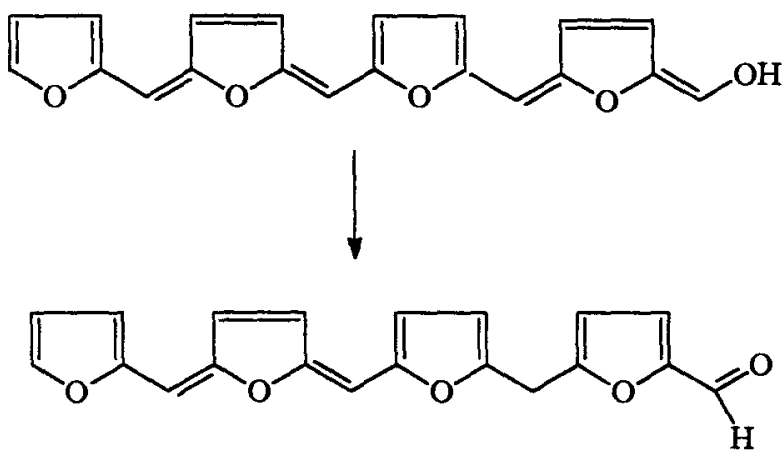

Figura 4.37-Equilíbrio ceto-enólico formado pela presença de conjugação em molécula de oligômero com número pares de mero.

Uma característica interessante associada à formação de agregados oligoméricos está relacionada ao seu tamanho. Os nossos resultados mostram que uma vez que o tamanho crítico necessário para formação de uma película é atingido, um mecanismo de proteção deve ser simultaneamente gerado. A necessidade dessa proteção advém da elevada capacidade de polimerização existente na superficie do capilar, devida a alta concentração de ácido. Permitida a continuação dessa reação, 
como de fato ocorre nos capilares de raio menores que $0,02 \mathrm{~mm}$, aonde a velocidade de queda é muito baixa, a polimerização se completaria chegando aos polímeros de cor negra, termofixos. Nesse caso esses polímeros são gerados a partir da baixa propagação da frente nos capilares de raio pequeno.

Dos mecanismos de proteção dos sítios químicos reativos, ambos são dependentes da agregação. Agregados grandes acabam por cair afastando-se da região de maior concentração de ácido, com isso diminuindo a sua taxa de reação. 0 outro mecanismo reside no detalhe do agregado, isto é, resulta da forma como as moléculas se organizam em estruturas mais complexas sob a ação do catalisador. Qualquer dos dois extremos do oligômero, seja a posição 5 do anel forneço seja o grupo hidroxila, que estiverem protegidos irá diminuir sensivelmente a taxa de conversão em polímeros lineares.

Podemos concluir do estudo da absorção óptica:

a) A banda em $345 \mathrm{~nm}$ é devida a dímeros do álcool furfurílico.

b) A espécie responsável pela banda em $460 \mathrm{~nm}$ ainda é desconhecida.

c) As bandas acima e uma outra pequena em 406nm são geradas nos processos de catálise ácida.

d) As bandas de $577 \mathrm{~nm}$ a $930 \mathrm{~nm}$ são devidas aos oligômeros dopados pelo ion $\mathrm{H}^{+}$.

e) Fazendo-se um paralelo com a aplicação do modelo do elétron numa caixa unidimensional para o $\beta$-caroteno encontra-se que a melhor descrição é aquela que atribui os oligômeros com 3,5,7 e 9 meros as bandas em $577 \mathrm{~nm}, 650 \mathrm{~nm}, 770 \mathrm{~nm}$ e $930 \mathrm{~nm}$, respectivamente.

f) Devido a elevada concentração da banda em $650 \mathrm{~nm}$ (5 mero) relativamente a concentração de dímeros nos oligômeros formados nos 
tubos, conclui-se que esse tamanho molecular é o menor tamanho que permite a auto-organização necessária a formação da película.

g) A baixa formação de oligômeros de cadeia mais longa, 9 mero, nos tubos é atribuída a duas causas: 1) a auto-organização forma agregados de grande tamanho, caindo para o interior do tubo. Assim a estrutura organizada se afasta da região de alta concentração de ácido. 2) como consequêencia da organização pode ocorrer uma menor exposição de um dos dois sítios ativos da cadeia ao processo de polimerização.

\section{5- PROPRIEDADES ELÉTRICAS}

A natureza condutora dos oligômeros dopados pelo $\mathrm{HCl}$ foi verificada por um processo bastante simples. Sobre uma lâmina de vidro com dois eletrodos de ouro, permanentemente ligados a um ohmimetro foram espalhadas 5 gotas de álcool furfurílico de forma a fazer uma película líquida uniforme que estivesse em contato com os eletrodos. A placa, na horizontal, foi arrumada de modo a ter a película líquida na sua parte inferior. Nessa condição o ohmimetro indicava uma resistência superior à $10 \mathrm{M} \Omega$, seu limite de medida. A boca de um frasco de vidro contendo $\mathrm{HCl}$ concentrado foi colocada sob a placa de vidro. Imediatamente iniciou-se a formação de cor esverdeada na placa aonde havia o álcool furfurílico. Logo a seguir o

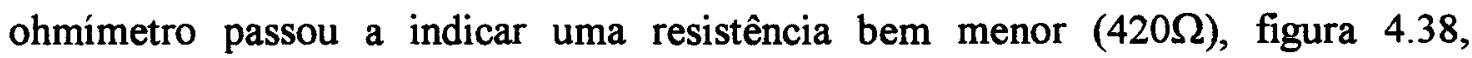
voltando posteriormente a indicar uma alta resistência maior que $10 \mathrm{M} \Omega$, coincidindo com o desenvolvimento da cor escura característica do polimero termofixo isolante. 


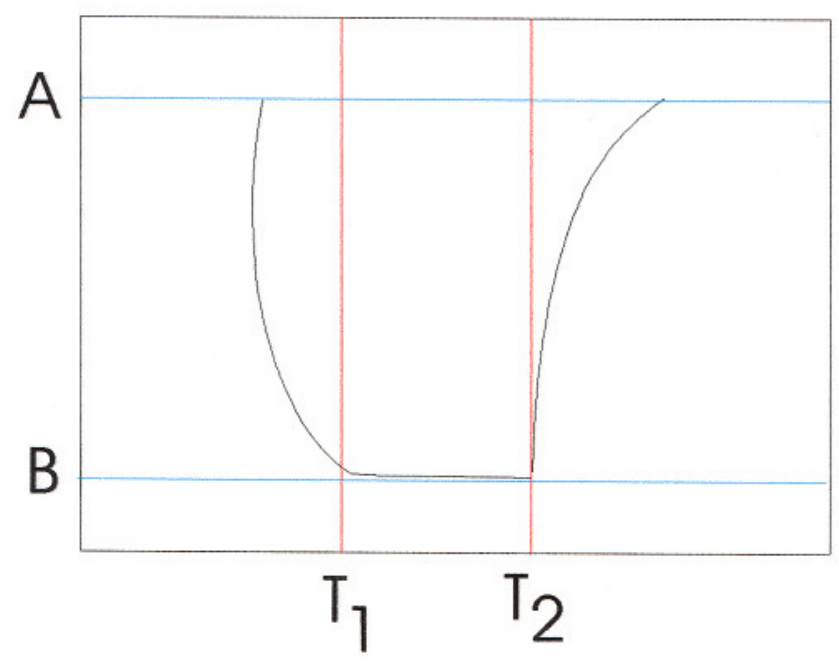

Figura 4.38-Representação do perfil da medida da resistência quando acontece a polimerização do álcool furfurílico. Aonde A é a maior resistência apontada pelo sistema $(10 \mathrm{M} \Omega)$, B é a menor resitência obtida $(420 \Omega), T_{1}$ é o tempo onde se inicia a menor resistência, $T_{2}$ é o tempo final aonde mesmo durante a exposição ao vapor do ácido, o sistema apresenta a menor resitência. Durante toda medida o álcool foi exposto ao vapor do ácido clorídrico.

Esse experimento simples mostra que a condução está associada à presença dos oligômeros que apresentam cor esverdeada por transmissão. Esses oligômeros estão associados aos primeiros estágios da reação de polimerização induzida por ácido. Uma vez que esses oligômeros transformem-se no polímero termofixo a condução cessa. Esse processo condutivo só é possível devido a auto-organização dos oligômeros formando a película. A capacidade da película resistir ao seu próprio peso até diâmetros de 5,0mm, mostra a existência de uma rede conectando os oligômeros que permite a percolação da corrente elétrica. 


\section{5-CONCLUSÕES}

- Este trabalho trata de um novo processo de polimerização do álcool furfurílico. A característica principal encontrada é uma mudança significativa na distribuição do peso molecular dos oligômeros formados em relação ao método de catálise homogênea. Em princípio, este método poderá ser aplicado em outros sistemas.

- Na interface monômero líquido-catalisador vapor a reação é intensa devido à alta concentração do catalisador. Nesse processo forma-se uma película de oligômeros por auto-organização. O detalhe da organização dessa película ainda não está elucidado, porém os resultados dessa organização foram claramente observados. A película tem uma estrutura porosa que permite a passagem do AF. Imagina-se que a elevada concentração de ácido na interface permite a formação de agregados moleculares através de forças viscosas atrativas. Em princípio, a intensidade dessas forças pode ser estimada pela tensão capaz de romper a película. Considerando-se esse fato imagina-se que essa película possa ser constituída a partir da agregação de micelas ou de vesículas. Em princípio, seria possível concentrar as soluções de oligômeros enquanto organizados.

- As estruturas dos oligômeros acima de três meros são dopadas pelo $\mathrm{HCl}$ por procedimento semelhante à dopagem da polianilina e de outros condutores eletrônicos orgânicos com estrutura conjugada. 
- Um resultado interessante é o de poder estimar o número mínimo de meros capaz de gerar a auto-organização que resulta na película. Esse número está em torno de cinco meros.

- Como resultado da formação da película de oligômeros a condução eletrônica ocorre por percolação pela malha de oligômeros organizados.

- O movimento de queda da película no interior do capilar é governado pelo equilíbrio entre forças gravitacionais e uma força de origem viscosa aplicada à periferia da película. A tensão mecânica na película é a responsável pelo seu rompimento para diâmetro dos capilares superiores a $5 \mathrm{~mm}$.

- A atribuição das bandas de absorção óptica como sendo devidas aos oligômeros dopados com número impar de meros encontra apoio na instabilidade das cadeias conjugadas com números pares de meros.

- Merece atenção o estudo de sistemas envolvendo a estabilização e a caracterização de estruturas de oligômeros lineares, produzidas em alta concentração através da catálise heterogênea. Sendo de fundamental importância para trabalhos futuros a elaboração de uma metodologia que permita, acompanhar o mecanismo de reação e formação de aglomerados desses oligômeros frente a ácidos.

- Ainda pode ser pensado em estender o mecanismo de catálise empregado para o álcool furfurílico, para outros polímeros condutores, como por exemplo, a polianilina. 


\section{6- BIBLIOGRAFIA}

1. GANDINI, A.; BELGACEM ,M.N. Furans in Polymer Chemistry: Syntheses and Properties of Materials. In "Progress in Polymers Science". CRC Press, 1996.

2.GANDINI, A.; Polymers From Renewable Resources. In "Comprehensive Polymer Science". Pergamon Press, Oxford, UK, p.527, 1992.

3.GANDINI, A.; COUTTEREZ, C. Synthesis and characterization of oligo(heteroarylene)s incorporating furan and Thiophene moietes. Polymer.,v.39, n.26, p.7004-14, 1998.

4.DUNLOP, A. P.; PETERS, F.N. The furans. American Chemical Society. Monography Series, 1953.

5.CHOURA, M; BELGACEM, N.M. GANDINI, A. Acid catalyzed polycondensation of furfuryl alcohol: mechanisms of chromophore formation and cross-linking. Macromolecules. v.29, p.3839-50,1996.

6.GONZALES, R.; MARTINEZ, R. ORTIZ, P. Polymerization of furfuryl alcohol with trifluoracetic acid: influence of experimental conditions. Macromol. Chem., v.193, p.1-9, 1992.

7.KRISHNA, T.A.; CHANDA, M. Kinetics of polymerization of furfuryl Alcohol in Aqueous Solution, Die Angewandte Makromolekulare Chemie. v.43, p.145-56, 1975.

8.PLATT, J.R.; Systematic of Eletronic Spectra of Conjugated Molecules. Papers of Chicago Group, John Wiley \& Sons, p.71-123,1964. 
9.KUNN, H.; A Quantum-Mechanical of Light Absorption of Organic Dyes and Similar Compounds. Journal of Chemical Physics. v.17, p.1198-2012, 1949.

10.BATISTA, P.S.; DE SOUZA, M.F. Furfuryl Alcohol Polymerization Inside of Capilaries. In : International Conference on Science and Tecnology of Syntetic Metals, Montpellier, France, p. 109, 1998.

11.SPENGE, S.; WINKELMANN, H. MARTINEZ, R. Composites From Furfuryl Alcohol and Inorganic solids by Cationic In, Die angewindte Macromolekulare Chemie, 208, p.125-31,1993.

12.MAGALÃES, W.L.E. .Impregnação de Pinus caribaea hondurensis com Álcool Furfurílico e Tetra-etil-ortosilicato. Dissertação de Mestrado IFSC-USP, São Paulo, 1998.

13.OZAKY, K.S.; Efeitos do Trảtamento da Madeira com Álcool Furfurílico Combinado com Compostos de Boro. Dissertação de Mestrado IFSC-USP, São Paulo, 1999.

14.SOLOMONS, T.W.; Organic Chemistry. $6^{\circ}$ ed. John Willey \& Sons, 1994.

15.DUNLOP, A.P.; SCHEGULLA, H. Production of Tetrahidrofurfuryl Alcohol; United States Patent Office. 2, 838, 523; 10, 1954.

16.GANDINI, A.; SALON, M. C. CHOURA, M. Furan chemistry and ionic polymerization: mechanisms and structures. Macromol. Chem., 60, p.165-176, 1992.

17.CHAU, W.C.; FAWCETT, A. H. MULEMWA, J.N. TAN, C.E. Copolymers of acrylonitrile with some furans and theirs Diels-Alder adducts. Polymer, v.26, p.1268-76, 1985.

18.Kircl-OTHEMER.; Encyclopedya of Chemical Tecnology. v.II, P.500-27.

19.REES, C.W.; SMITHEN, C.E.; Reactions of Heterocyclic Compounds with Carbenes. In: Advances in heterocyclic Chemistry. v.3, P63-5, Academic Press, New York, 1964. 
20.SPECTOR,W. S.; Handbook of Toxicology. v.I, p.146-7. Saunders, Philadelpphia, 1956.

21.WINDHOLZ, M; The Merck Index-An encyclopedia of chemical, drugs, and biologicals. $10^{\circ}$ edition, Merck \& CO, p.614, 1983.

22. VOGEL, A. I.; Análise Orgânica. v.3, p.876, Ao Livro Tecnico S.A., São Paulo, 1971.

23.FLORY, J.P.; Principles of Polymer Chemistry. Cornell University Press., $1^{\circ} \mathrm{ed}$, 1953.

24.MACIEL, G.E.; CHUANG, I.S.; HAMMONS, G.E. 13C NMR Study of Cured Furfuryl Alcohol Resins using cross polarization and magic-angle spinning. Macromoolecules, v.15, p.1218-20, 1982.

25.WEWERKA, E.M.; LONGHRAN, E.D.; WATERS, G.J. A mass spectrometric study of substituted furfuryl compounds. Jornal Applied Polymer Science. v.15, p.1437, 1971.

26.PORTER, Q.N.; Mass Spectrometry of heterocyclic Compounds., $2^{\circ}$ edition, John Wiley \& Sons, 1985.

27.GONZALES, R.; MARTINEZ, R.; ORTIZ, P.; Polymerization of Furfuryl Alcohol with trifluoracetic acid. The Formation of Difurfuryl Eter. Macromol. Chem. v.13, p.517-23, 1992.

28.ATKINS, P.W.; Physical Chemistry. $5^{\circ}$ ed. Oxford University Press, 1994.

29.KALER, E.W.,RODRIGUEZ,B.E, MURTHY, A .K., ZASADZINSKI; Science, 245, p.1371, 1989.

30.TINOCO, I. Jr.; SAUER, K; WANG, J.C. Physical Chemistry - Priciples and applications in Biological Sciences. $3^{\circ}$ edition. SIMON \& SCHUSTER CO 1995. 
31.SPERLING, L.H.; Introduction to Physical Polymer Science. $2^{\circ}$ edition. John Wiley \& Sons, New York, 1992.

32.LEVINE, I.N.; Quantum Chemistry. $2^{\circ}$ edition., Allyn and Bacon Inc, 1970.

33.TREDGOLD, R. H.; Order in thin organic films., $1^{\circ}$ edition, Cambridge University Press, p. 116-128, 1994.

34.SAFRAN, S.A.; Statistical Thermodynamics of Surface, Interface and Membranes. Addison-Wesley Publishing Company, 1994

35.ISRAELACHVILI, J.N.; Intermolecular \& Surfaces Forces., $2^{\circ}$ edition. Academic Press, 1992.

36.KU, C.C.; LIEPINS, R. Eletrical properties of polymers, chemical principles. Hanser publishers, 1987.

37. STRYER, L.; Biochemistry. $3^{\circ}$ edition, W.H. Freeman CO, p. 315-515, 1988

38.ADAMSON, A.W.; Physical Chemistry of Surfaces. $5^{\circ}$ edition, John Wiley \& Sons, 1990.

39. ROBINSON, J.W.; Pratical Handbook of Spectroscopy, CRC Press, p3-170, 1991.

40.ALEXANDER, L.E.; X-Ray diffraction Methods in Polymer Science. $1^{\circ}$ edition, John Wiley \& Sons, p.137-234, 1969. 